\title{
Late to the Party: Synthesis and Characterization of Tellurium and Selenium Half-Sandwich Complexes
}

Jerod M. Kieser, ${ }^{\mathrm{a}}$ Leighton O. Jones, ${ }^{\mathrm{b}}$ Madeleine C. Uible, ${ }^{\mathrm{a}}$ Matthias Zeller, ${ }^{\mathrm{a}}$ George C. Schatz, , and Suzanne C. Bart $^{\mathrm{a}^{*}}$

${ }^{a}$ H. C. Brown Laboratory, Department of Chemistry, Purdue University, West Lafayette, Indiana 47907, United States

${ }^{\mathrm{b}}$ Department of Chemistry, Northwestern University, Evanston, Illinois 60208, United States

Experimental Details.................................................................................................. 2

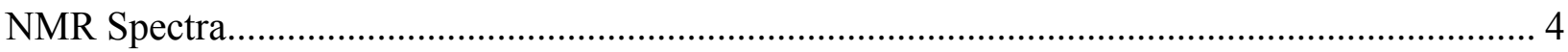

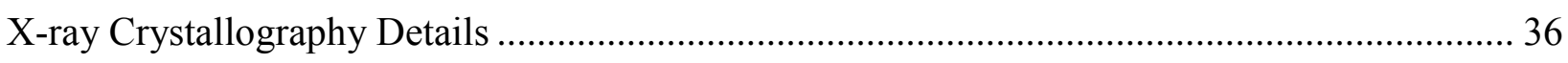

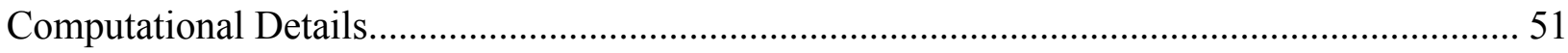

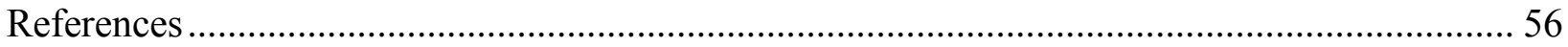




\section{Experimental details}

General Considerations:

All manipulations were carried out under an inert atmosphere of nitrogen or argon using either an MBraun glove box or standard Schlenk line techniques, unless stated otherwise. All chemicals were purchased from commercial sources and used as received, unless stated otherwise. THF, diethyl ether, and pentane were purified through a Seca solvent purification system and stored over molecular sieves. $N, N, N^{\prime}, N^{\prime}$-tetramethylethylenediamine (TMEDA) was dried and distilled over $\mathrm{CaH}_{2}$ and degassed with three freeze-pump-thaw cycles. $\mathrm{LiCp}^{\mathrm{Me} 4}$ was synthesized by deprotonation of 1,2,3,4tetramethylcyclopenta-1,3-diene with $n$-butyllithium in pentane at $0{ }^{\circ} \mathrm{C}$. $\mathrm{KCp}^{*}$ was synthesized by deprotonation of 1,2,3,4,5-pentamethylcyclopenta-1,3-diene with potassium hydride in $\mathrm{THF}$. $\mathrm{Ph}_{3} \mathrm{TeCl}^{1}$ $\left[\mathrm{Ph}_{3} \mathrm{Te}\right]\left[\mathrm{S}_{2} \mathrm{CNEt}_{2}\right]{ }^{2}$ and $\mathrm{Ph}_{3} \mathrm{SeCl}^{3}$ were synthesized according to literature procedures. Deuterated solvents were purchased from Cambridge Isotope Laboratories. Benzene- $d_{6}$ was dried over molecular sieves and sodium and degassed with six freeze-pump-thaw cycles. THF- $d_{8}$ was dried and stored over sodium. NMR spectra were recorded on Bruker AVANCE III $400 \mathrm{MHz}$ or Bruker DRX $500 \mathrm{MHz}$ spectrometers and chemical shifts are given in ppm and referenced to residual solvent signal $\left({ }^{1} \mathrm{H}\right.$ and $\left.{ }^{13} \mathrm{C}\right)$ or an external standard $\left({ }^{125} \mathrm{Te}: 0.5 \mathrm{M} \mathrm{Ph} \mathrm{Te}_{2}\right.$ in DCM-d,$\left.\delta 422 \mathrm{ppm} ;{ }^{77} \mathrm{Se}: \mathrm{Ph}_{2} \mathrm{Se}_{2}, \delta 460 \mathrm{ppm}\right) .{ }^{4} \mathrm{All} 2 \mathrm{D}$ ${ }^{1} \mathrm{H}$ DOSY spectra were recorded on a Bruker DRX $500 \mathrm{MHz}$ spectrometer with a $5 \mathrm{~mm}$ BBO probe using a z-gradient coil with a maximum nominal field strength of $50 \mathrm{G} \mathrm{cm}^{-1}$. Spectra were acquired using a standard ledbpgp2s pulse program with the z-gradient varied linearly between 5-95\% over 16 steps, collected as 16 spectra on $16 \mathrm{~K}$ data points, and diffusion coefficients calculated using the T1/T2 module in Topspin 3.6.3. All spectra were acquired at $298 \mathrm{~K}$ with sample spinning disabled, diffusion time $\Delta=$ $0.1 \mathrm{~s}$, and length of gradient $\delta / 2=1.5 \mathrm{~ms}$. Diffusion coefficients were corrected using tetrakis(trimethylsilyl)silane as internal standard per the ECC-DOSY method. ${ }^{5}$

Synthesis of $[\mathrm{Cp}]\left[\mathrm{TePh}_{3}\right](\mathbf{1})$

A solution of $\operatorname{LiCp}(0.186 \mathrm{~g}, 2.58 \mathrm{mmol})$ and TMEDA $(0.748 \mathrm{~g}, 6.43 \mathrm{mmol})$ in diethyl ether $(15 \mathrm{~mL})$ was added dropwise to a slurry of $\left[\mathrm{Ph}_{3} \mathrm{Te}\right]\left[\mathrm{S}_{2} \mathrm{CNEt}_{2}\right](0.665 \mathrm{~g}, 1.31 \mathrm{mmol})$ in diethyl ether $(10 \mathrm{~mL})$ at room temperature. The resulting yellow slurry was stirred for 1 hour, then the precipitate was separated by filtration and washed with a second portion of TMEDA in $5 \mathrm{~mL}$ diethyl ether. Precipitate was additionally washed with diethyl ether $(3 \times 10 \mathrm{~mL})$ followed by removal of volatiles under vacuum to give 1 as a bright yellow solid (0.504 g, $91 \%$ ). ${ }^{1} \mathrm{H}$ NMR (500 MHz, THF-d8, 298K): $\delta 7.51-7.39$ (m, 15H), 5.81 (s, $5 \mathrm{H}) .{ }^{13} \mathrm{C}$ NMR $\left(126 \mathrm{MHz}, \mathrm{THF}-d_{8}, 298 \mathrm{~K}\right): \delta 138.60,134.02,131.32,130.95,109.89 .{ }^{125} \mathrm{Te} \mathrm{NMR}(158$ MHz, THF-d8, 298K): $\delta 1048.08 .{ }^{1} \mathrm{H}$ NMR (500 MHz, benzene-d6, 298K): $\delta 7.36(\mathrm{~d}, J=8.25 \mathrm{~Hz}, 6 \mathrm{H})$, 6.96-6.87 (m, 9H), $6.52(\mathrm{~s}, 5 \mathrm{H}) .{ }^{13} \mathrm{C}$ NMR (126 MHz, benzene-d6, 298K): $\delta 138.37,133.20,130.24$, 130.07, 110.54. M.p. $136-140{ }^{\circ} \mathrm{C}$ (dec.).

Synthesis of $\left[\mathrm{Cp}^{\mathrm{Me} 4}\right]\left[\mathrm{TePh}_{3}\right](\mathbf{2})$

$\mathrm{Ph}_{3} \mathrm{TeCl}(0.055 \mathrm{~g}, 0.14 \mathrm{mmol})$ and $\mathrm{LiCp}^{\mathrm{Me} 4}(0.018 \mathrm{~g}, 0.14 \mathrm{mmol})$ were weighed into a $20 \mathrm{~mL}$ scintillation vial and cooled to $-35{ }^{\circ} \mathrm{C}$. Then, diethyl ether $\left(3 \mathrm{~mL}\right.$, prechilled to $\left.-35^{\circ} \mathrm{C}\right)$ was added to the solids and the resulting slurry stirred for 16 hours at $-35^{\circ} \mathrm{C}$. After, the dark red slurry was cold filtered, and the filtrate quickly evaporated to give $\mathbf{2}$ as a dark red crystalline solid. The yield of $\mathbf{2}$ was determined by allowing the filtrate to first warm to room temperature and decompose. Volatiles were then removed under vacuum, the residue extracted into pentane $(1 \mathrm{~mL})$, and the extract concentrated to a yellow oil 
$(0.058 \mathrm{~g}, 86 \%)$ under vacuum. The internally referenced ${ }^{1} \mathrm{H}$ NMR spectrum of this oil provided yields for the thermal decomposition products $\mathrm{Ph}_{2} \mathrm{Te}(0.12 \mathrm{mmol}, 84 \%)$ and two isomers of phenyltetramethylcyclopentadiene (major: $0.09 \mathrm{mmol}, 64 \%$ and minor: $0.02 \mathrm{mmol}, 14 \%)$. ${ }^{1} \mathrm{H}$ NMR (400 MHz, THF- $\left.d_{8}, 238 \mathrm{~K}\right): \delta 7.45$ (br s, 9H), 7.38 (br s, 6H), $5.51(\mathrm{~s}, 1 \mathrm{H}), 1.94(\mathrm{~s}, 6 \mathrm{H}), 1.82(\mathrm{~s}, 6 \mathrm{H}) .{ }^{13} \mathrm{C} \mathrm{NMR}$ $\left(101 \mathrm{MHz}, \mathrm{THF}-d_{8}, 238 \mathrm{~K}\right): \delta 138.03,134.04,131.03,130.86,118.82,116.88,106.98,14.04,12.05 .{ }^{125} \mathrm{Te}$ NMR (126 MHz, THF- $\left.d_{8}, 238 \mathrm{~K}\right): \delta 1020.31$.

Synthesis of $\left[\mathrm{Cp}^{*}\right]\left[\mathrm{TePh}_{3}\right](\mathbf{3})$

$\mathrm{Ph}_{3} \mathrm{TeCl}(0.051 \mathrm{~g}, 0.13 \mathrm{mmol})$ and $\mathrm{KCp}^{*}(0.022 \mathrm{~g}, 0.13 \mathrm{mmol})$ were weighed into a $20 \mathrm{~mL}$ scintillation vial and cooled to $-35^{\circ} \mathrm{C}$. Then, diethyl ether $\left(3 \mathrm{~mL}\right.$, prechilled to $\left.-35^{\circ} \mathrm{C}\right)$ was added to the solids and the resulting slurry stirred for 16 hours at $-35^{\circ} \mathrm{C}$. After, the dark red slurry was cold filtered, and the filtrate quickly evaporated to give $\mathbf{3}$ as a dark red crystalline solid. The yield of $\mathbf{3}$ was determined by allowing the filtrate to first warm to room temperature and decompose. Volatiles were then removed under vacuum, the residue extracted into pentane $(1 \mathrm{~mL})$, and the extract concentrated to a yellow oil $(0.040 \mathrm{~g}, 62 \%)$ under vacuum. The internally referenced ${ }^{1} \mathrm{H}$ NMR spectrum of this oil provided yields for the thermal decomposition products $\mathrm{Ph}_{2} \mathrm{Te}(0.07$ mmol, 53\%) and 5-phenyl-1,2,3,4,5pentamethylcyclopenta-1,3-diene (0.07 mmol, 53\%). ${ }^{1} \mathrm{H}$ NMR (400 MHz, THF- $\left.d_{8}, 238 \mathrm{~K}\right): \delta$ 7.47-7.42 $(\mathrm{m}, 9 \mathrm{H}), 7.35-7.31(\mathrm{~m}, 6 \mathrm{H}), 1.90(\mathrm{~s}, 15 \mathrm{H}) .{ }^{13} \mathrm{C}$ NMR $\left(101 \mathrm{MHz}, \mathrm{THF}-d_{8}, 238 \mathrm{~K}\right): \delta 139.49,134.04$, $130.90,130.82,116.00,12.04 .{ }^{125} \mathrm{Te}$ NMR $\left(126 \mathrm{MHz}, \mathrm{THF}-d_{8}, 238 \mathrm{~K}\right): \delta 1009.32$.

Synthesis of $[\mathrm{Cp}]\left[\mathrm{SePh}_{3}\right](4)$

A solution of LiCp $(0.052 \mathrm{~g}, 0.72 \mathrm{mmol})$ and TMEDA $(0.207 \mathrm{~g}, 1.78 \mathrm{mmol})$ in diethyl ether $(4 \mathrm{~mL}$, prechilled to $\left.-35^{\circ} \mathrm{C}\right)$ was added dropwise to a slurry of $\mathrm{Ph}_{3} \mathrm{SeCl}(0.124 \mathrm{~g}, 0.36 \mathrm{mmol})$ in diethyl ether (1 $\mathrm{mL}$ ) at $-35^{\circ} \mathrm{C}$. The resulting yellow slurry was stirred for 16 hours at $-35^{\circ} \mathrm{C}$, then the precipitate was separated by cold filtration and washed with a second portion of TMEDA in $3 \mathrm{~mL}$ cold diethyl ether. The precipitate was additionally washed with cold diethyl ether $(3 \times 5 \mathrm{~mL})$ followed by removal of volatiles under vacuum to give 4 as a bright yellow solid (0.112 g, 83\%). ${ }^{1} \mathrm{H}$ NMR (500 MHz, THF- $\left.d_{8}, 298 \mathrm{~K}\right): \delta$ 7.52-7.43 (m, 15H), $5.71(\mathrm{~s}, 5 \mathrm{H}) .{ }^{13} \mathrm{C}$ NMR (126 MHz, THF- $\left.d_{8}, 298 \mathrm{~K}\right): \delta 131.90,131.16,130.84,108.49$. ${ }^{77} \mathrm{Se}$ NMR (76 MHz, THF- $\left.d_{8}, 298 \mathrm{~K}\right)$ : No ${ }^{77}$ Se resonance observed after 1024 transients.

Synthesis of $\left[\mathrm{Cp}^{*}\right]\left[\mathrm{SePh}_{3}\right](\mathbf{5})$

$\mathrm{Ph}_{3} \mathrm{SeCl}(0.050 \mathrm{~g}, 0.14 \mathrm{mmol})$ and $\mathrm{KCp}^{*}(0.025 \mathrm{~g}, 0.14 \mathrm{mmol})$ were weighed into a $20 \mathrm{~mL}$ scintillation vial and cooled to $-35^{\circ} \mathrm{C}$. Then, THF- $d_{8}\left(1 \mathrm{~mL}\right.$, pre-chilled to $\left.-35{ }^{\circ} \mathrm{C}\right)$ was added to the solids and the dark red slurry stirred for 30 minutes at $-35{ }^{\circ} \mathrm{C}$. Attempts to purify 5 were met with immediate decomposition as indicated by loss of red color. The yield of 5 was determined by filtering the reaction mixture and allowing the filtrate to warm to room temperature. Volatiles were then removed under vacuum, the residue extracted into pentane $(1 \mathrm{~mL})$, and the extract concentrated to a yellow oil $(0.040 \mathrm{~g}$, $62 \%)$ under vacuum. The internally referenced ${ }^{1} \mathrm{H}$ NMR spectrum of this oil provided the yield for the major thermal decomposition product $\mathrm{Ph}_{2} \mathrm{Se}(0.07 \mathrm{mmol}, 51 \%) .{ }^{1} \mathrm{H}$ NMR $\left(400 \mathrm{MHz}, \mathrm{THF}-d_{8}, 238 \mathrm{~K}\right): \delta$ 7.49 (br, 9H), 7.30 (br, 6H), 1.84 (s, 15H). ${ }^{13} \mathrm{C}$ NMR (101 MHz, THF-ds, 238K): $\delta$ 139.73, 131.31, $130.86,130.69,113.62,12.49 .{ }^{77} \mathrm{Se}$ NMR $\left(76 \mathrm{MHz}, \mathrm{THF}-d_{8}, 238 \mathrm{~K}\right): \delta 587.65$. 
NMR Spectra

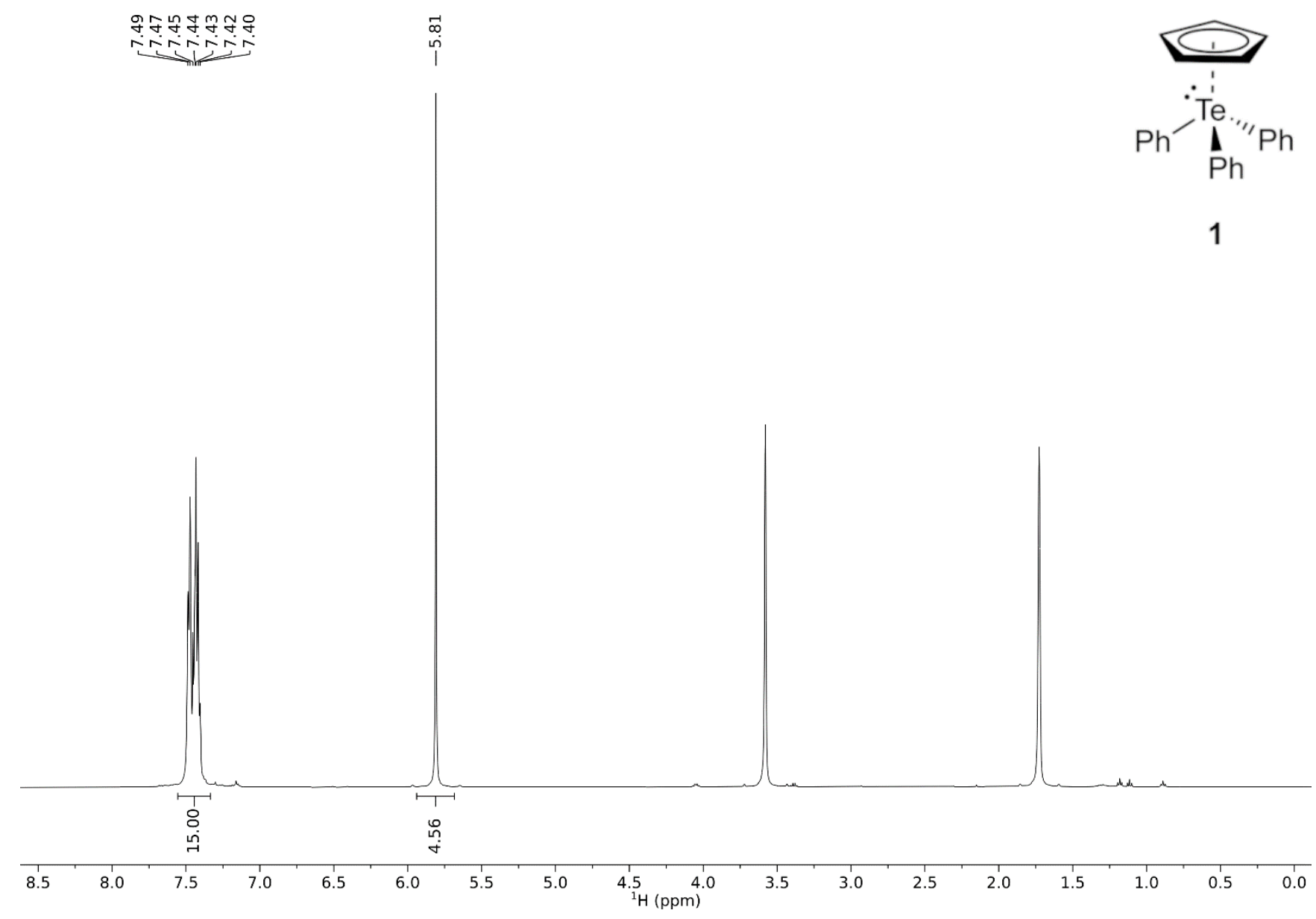

Figure S1. ${ }^{1} \mathrm{H}$ NMR spectrum $\left(500 \mathrm{MHz}, \mathrm{THF}-d_{8}, 298 \mathrm{~K}\right)$ of $\mathbf{1}$. 


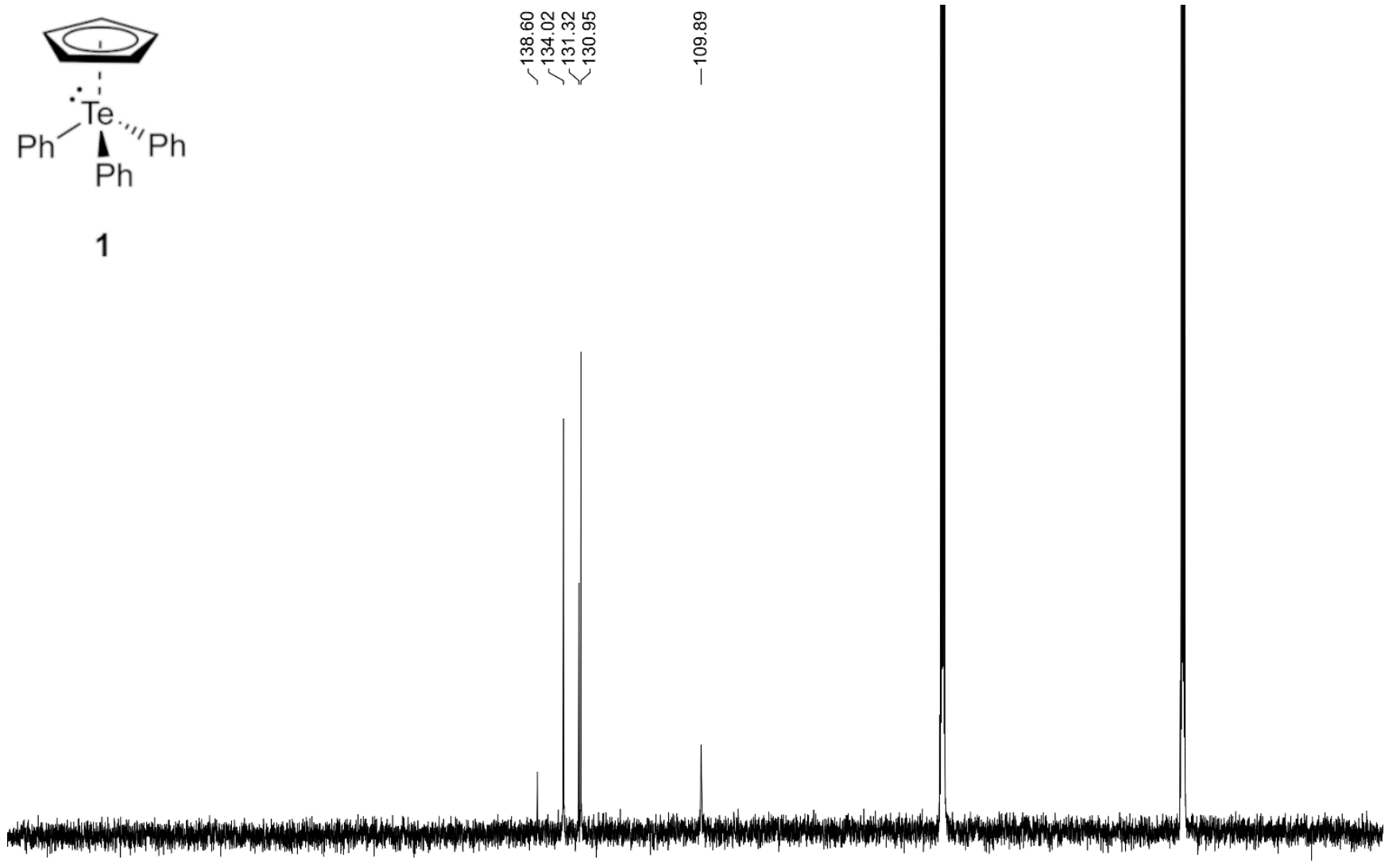

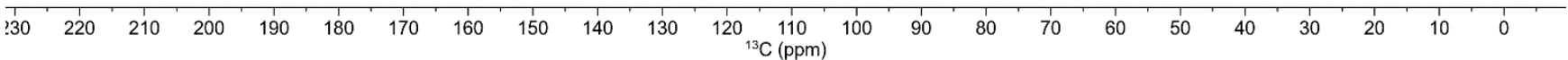

Figure S2. ${ }^{13} \mathrm{C}$ NMR spectrum (126 MHz, THF- $\left.d_{8}, 298 \mathrm{~K}\right)$ of $\mathbf{1}$. 

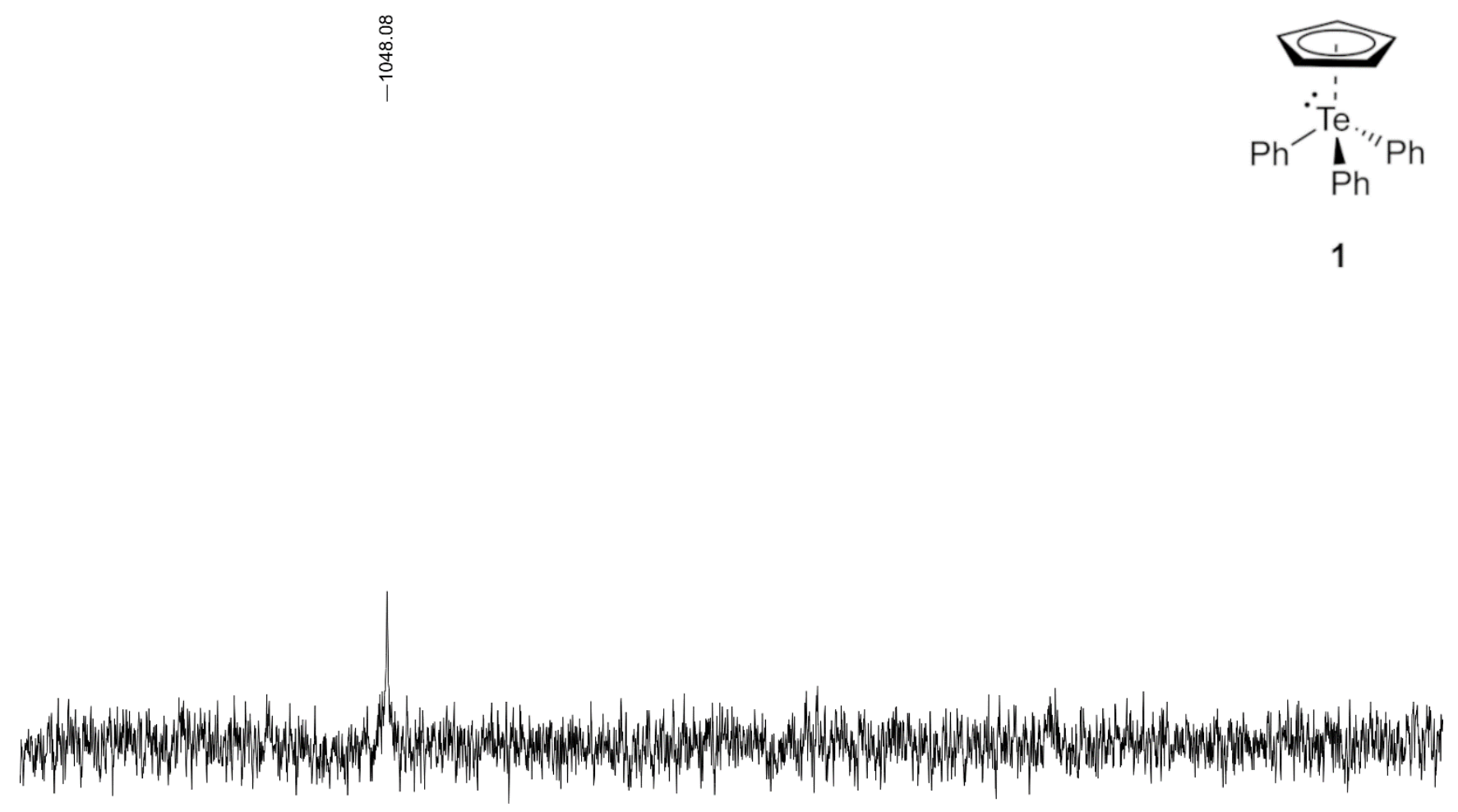

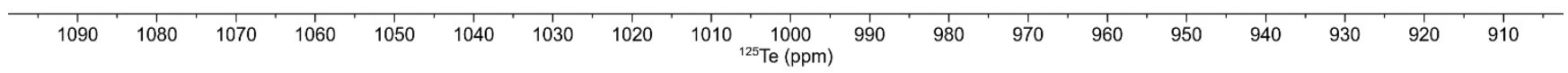

Figure S3. ${ }^{125} \mathrm{Te}$ NMR spectrum (158 MHz, THF- $\left.d_{8}, 298 \mathrm{~K}\right)$ of $\mathbf{1}$. 


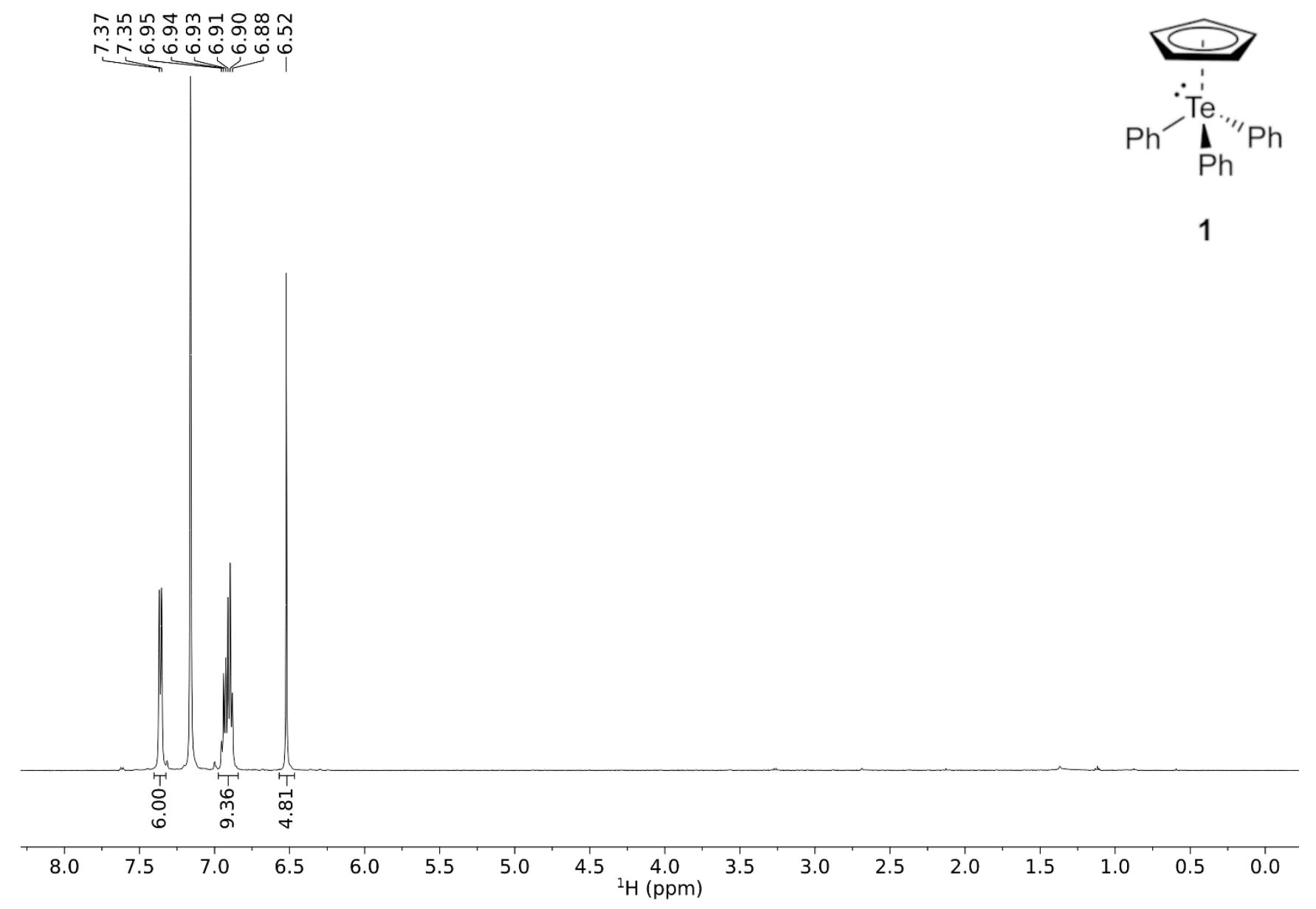

Figure S4. ${ }^{1} \mathrm{H}$ NMR spectrum $\left(500 \mathrm{MHz}\right.$, benzene- $\left.d_{6}, 298 \mathrm{~K}\right)$ of $\mathbf{1}$. 


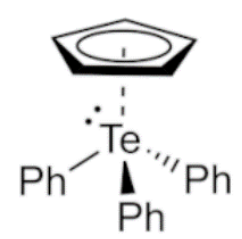

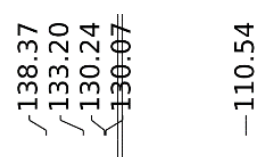

1

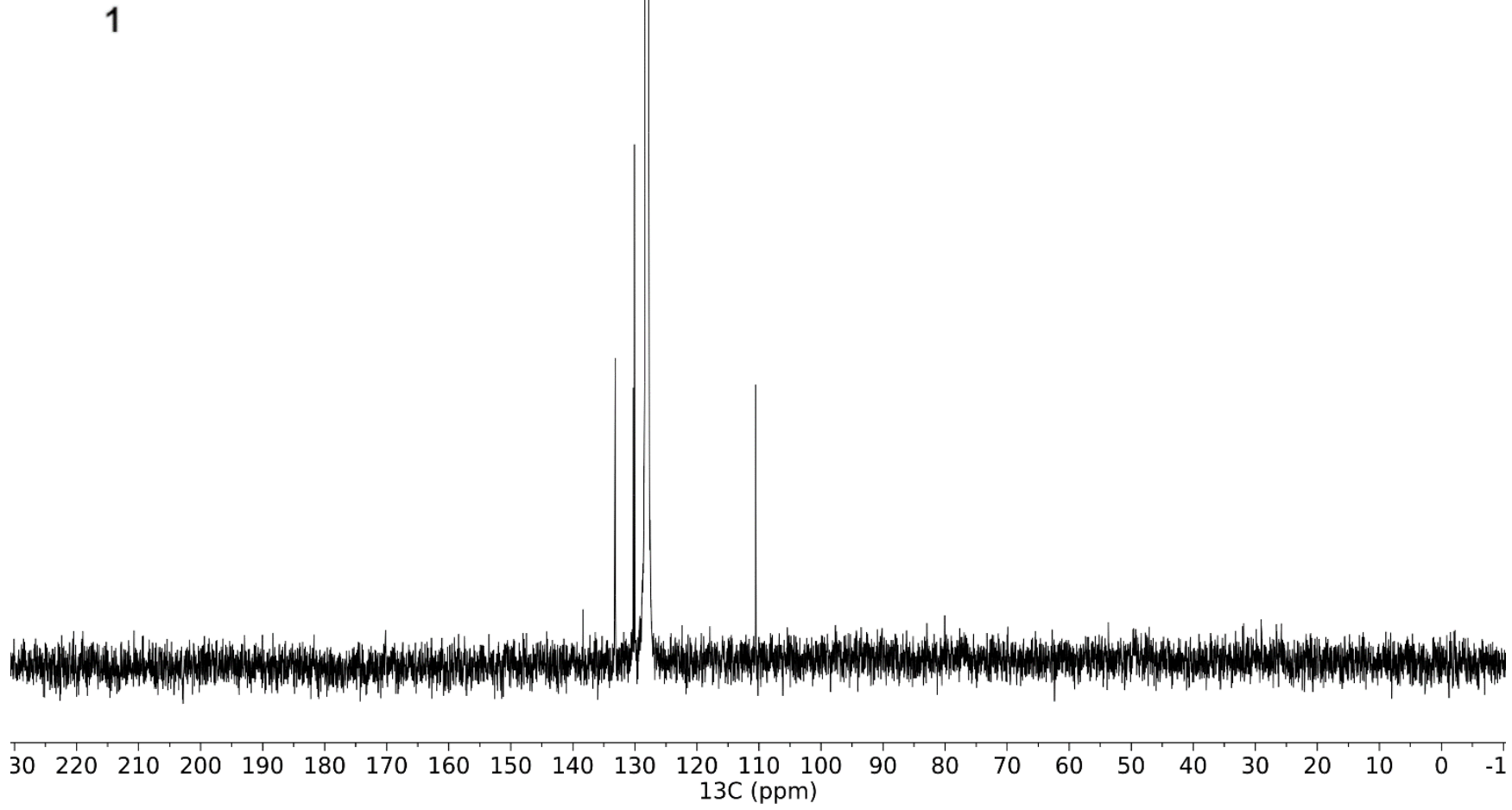

Figure S5. ${ }^{13} \mathrm{C}$ NMR spectrum $\left(126 \mathrm{MHz}\right.$, benzene- $\left.d_{6}, 298 \mathrm{~K}\right)$ of $\mathbf{1}$. 


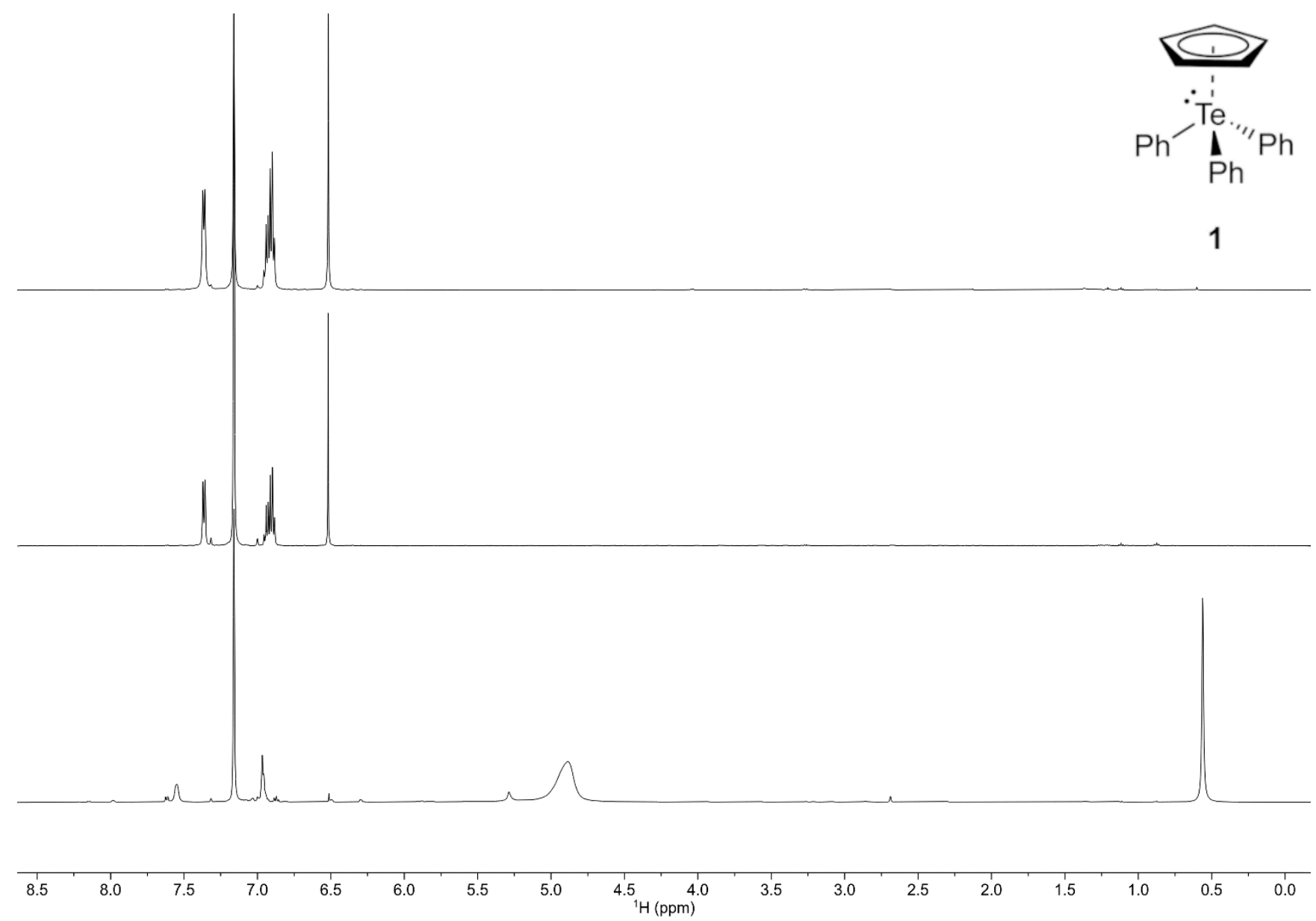

Figure S6. ${ }^{1} \mathrm{H}$ NMR spectrum $\left(500 \mathrm{MHz}\right.$, benzene- $\left.d_{6}, 298 \mathrm{~K}\right)$ of $\mathbf{1}$. Top: freshly prepared solution of 1. Middle: solid sample of 1 exposed to air for 4 hours prior to dissolution. Bottom: addition water to solution of 1 . 


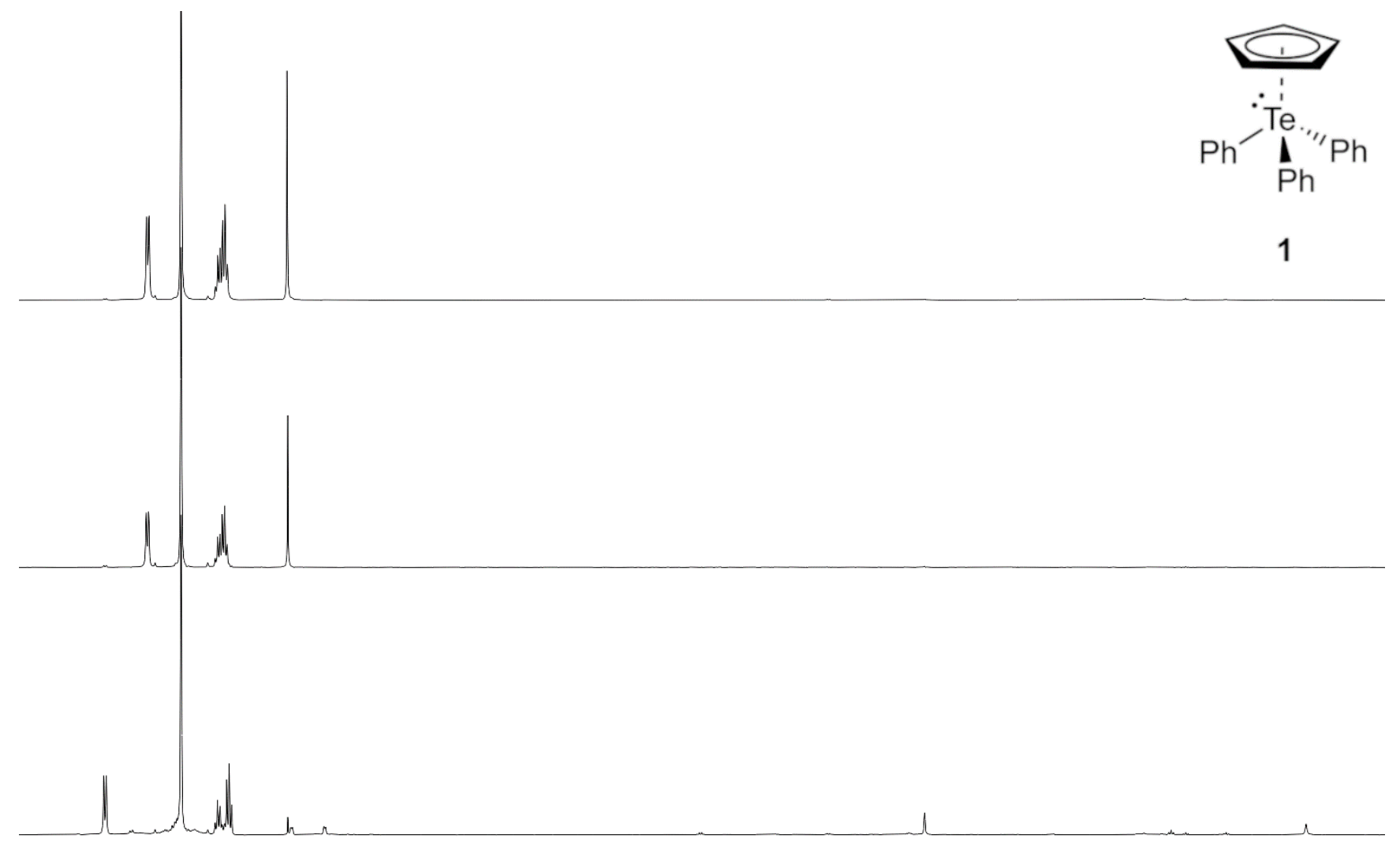

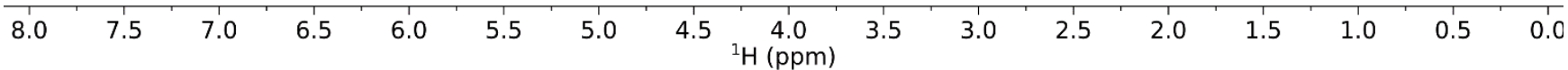

Figure S7. ${ }^{1} \mathrm{H}$ NMR spectrum $\left(500 \mathrm{MHz}\right.$, benzene- $\left.d_{6}, 298 \mathrm{~K}\right)$ of $\mathbf{1}$. Top: freshly prepared solution of 1. Middle: solid sample of $\mathbf{1}$ heated at $50{ }^{\circ} \mathrm{C}$ in a sealed, nitrogen filled $\mathrm{J}$ Young tube for 24 hours before dissolution. Bottom: solution of 1 stored at room temperature in a sealed, nitrogen filled J Young tube for 24 hours before analysis. 


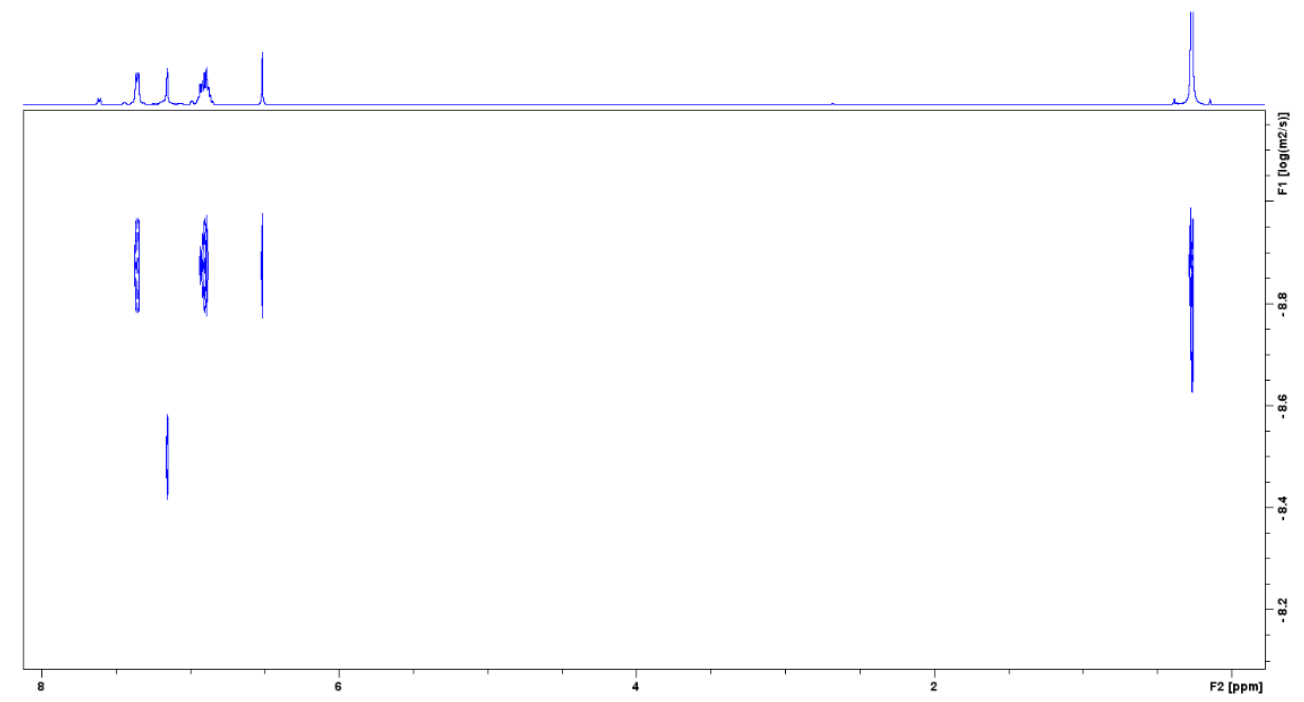

Figure S8. 2D ${ }^{1} \mathrm{H}$ DOSY-NMR spectrum of 1 (benzene-d6, $298 \mathrm{~K}, 5 \mathrm{mM}$ ).

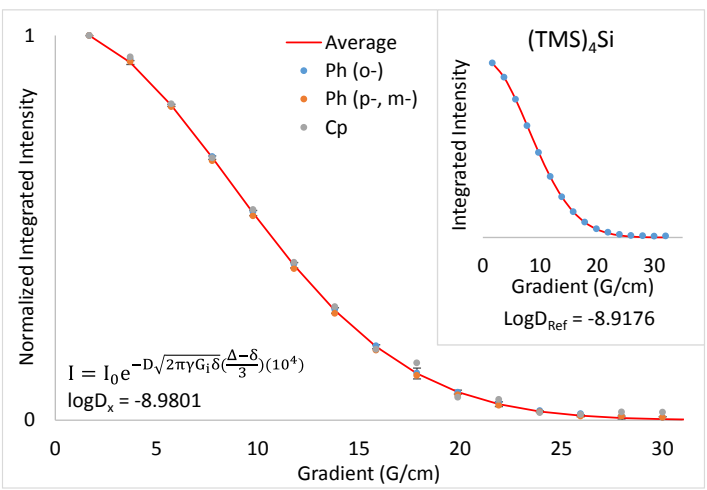

Figure S9. Calculated relaxation curve fits for $\mathbf{1}$ in benzene- $d_{6}$.

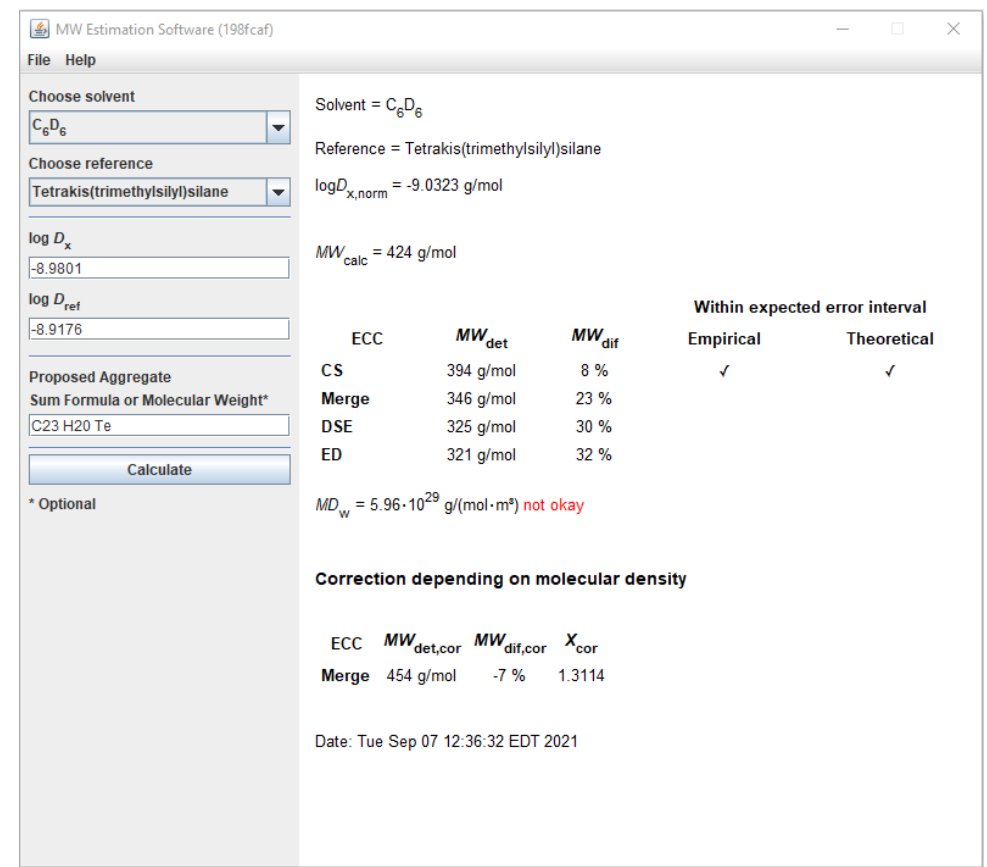

Figure S10. Molecular weight calculation for 1 in benzene- $d_{6}{ }^{5}$ 


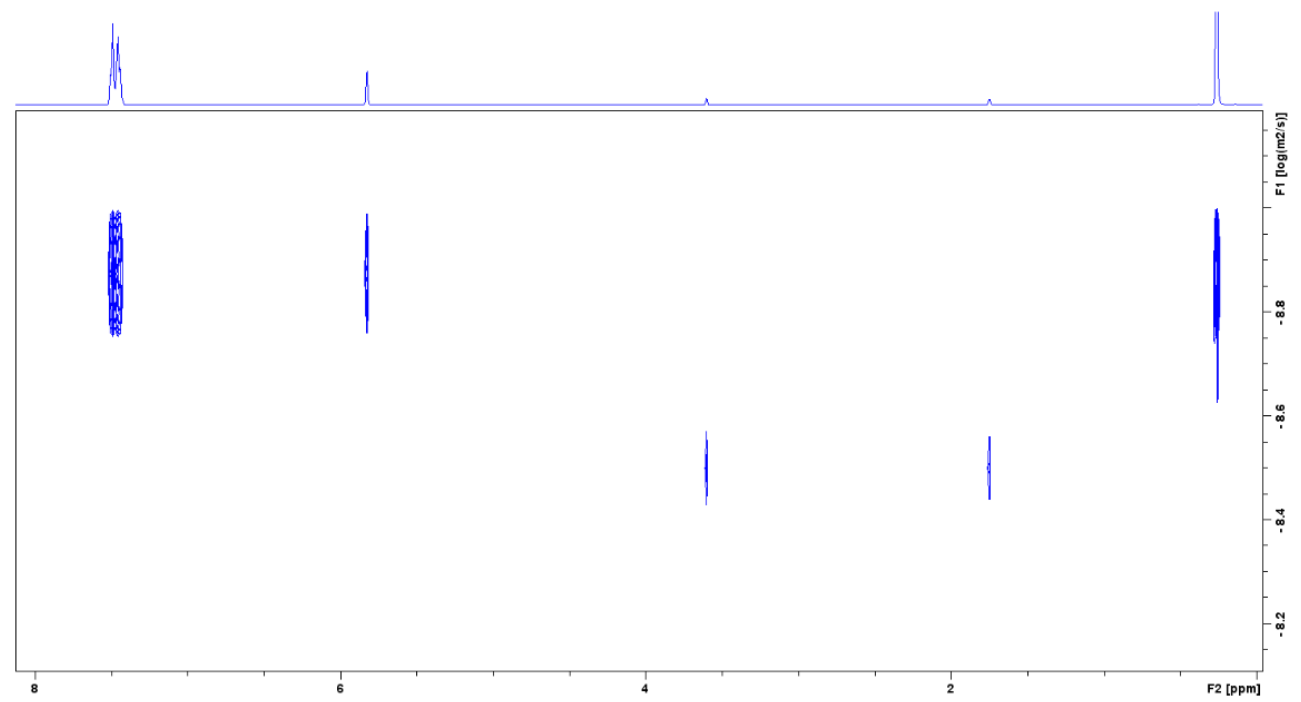

Figure S11. 2D ${ }^{1} \mathrm{H}$ DOSY-NMR spectrum of 1 (THF- $d_{8}, 298 \mathrm{~K}, 11 \mathrm{mM}$ ).

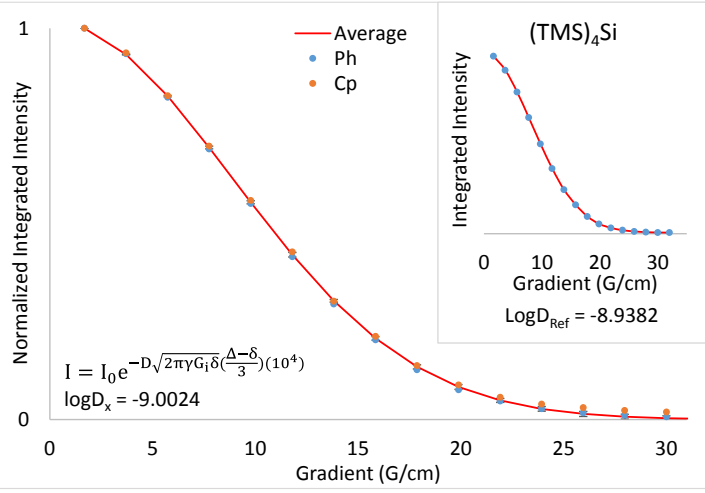

Figure S12. Calculated relaxation curve fits for 1 in THF- $d_{8}$.

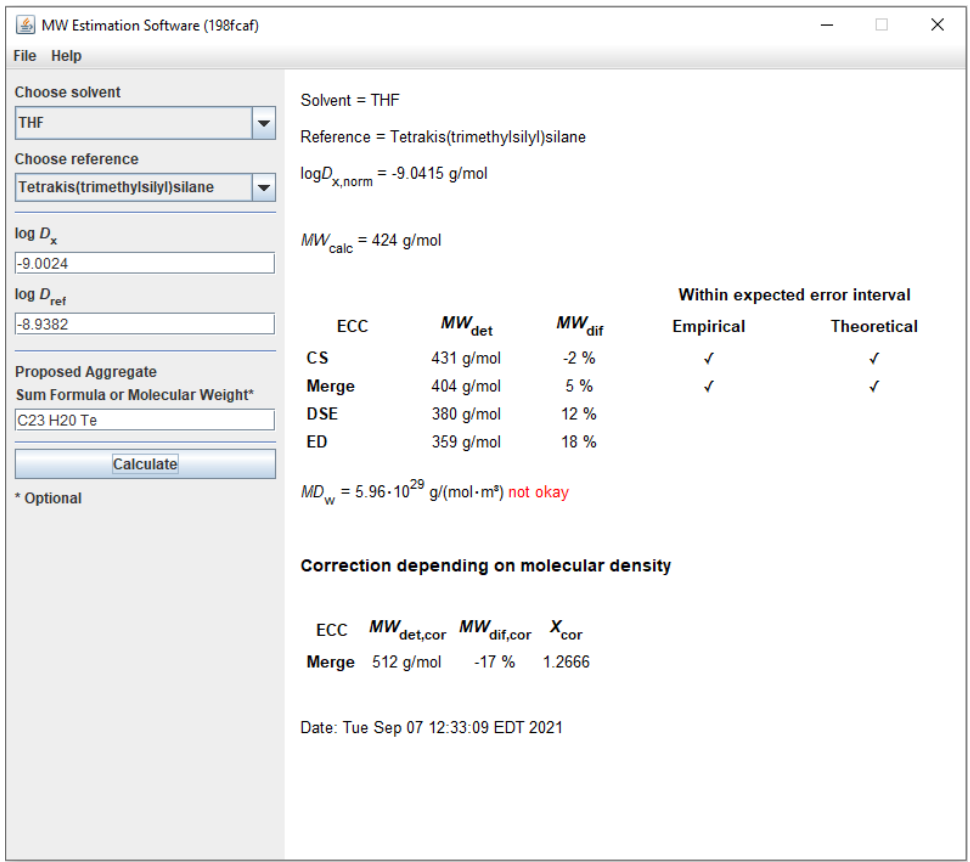

Figure S13. Molecular weight calculation for 1 in THF- $d_{8}{ }^{5}$ 


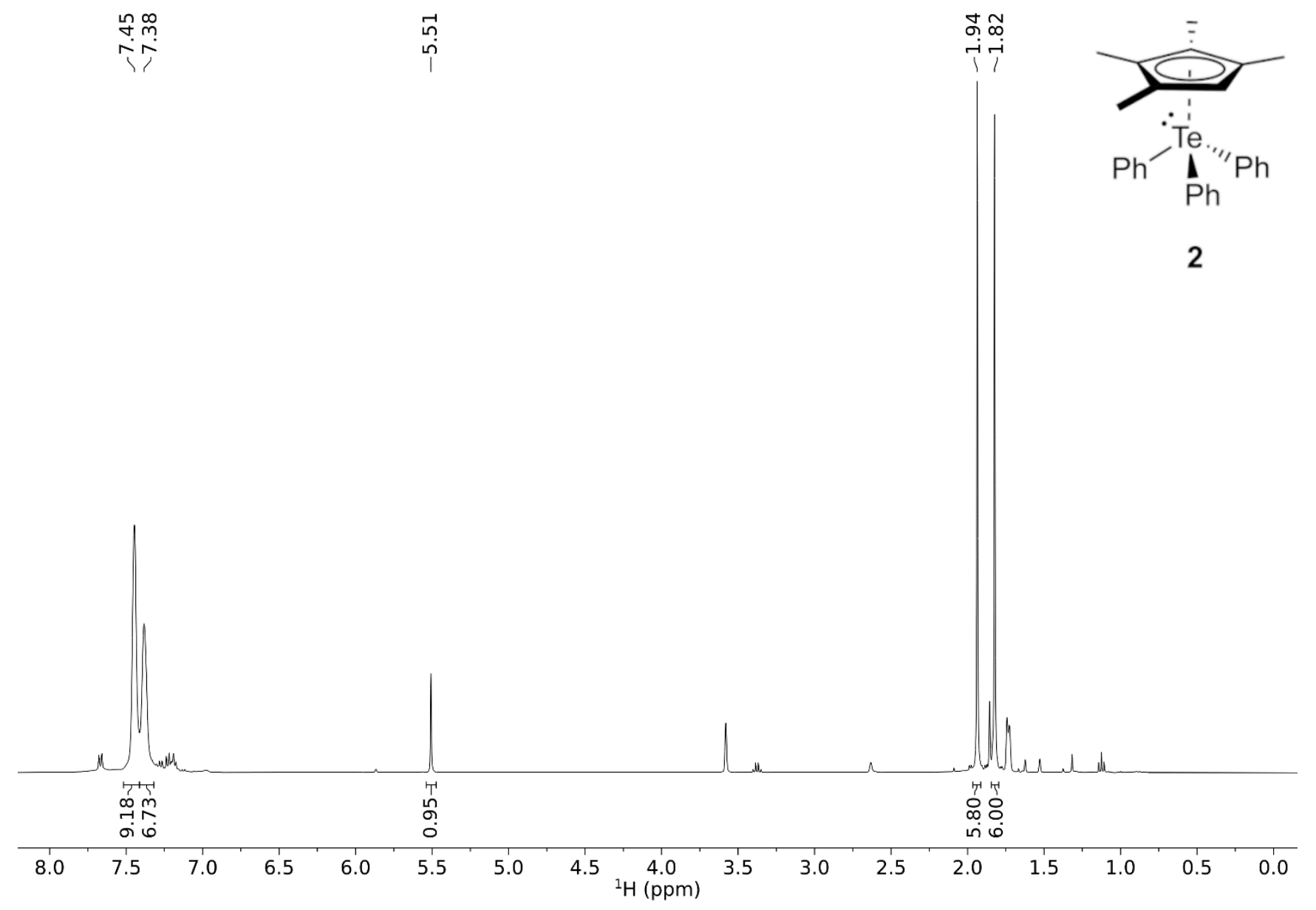

Figure S14. ${ }^{1} \mathrm{H}$ NMR (400 MHz, THF- $\left.d_{8}, 238 \mathrm{~K}\right)$ of 2. 

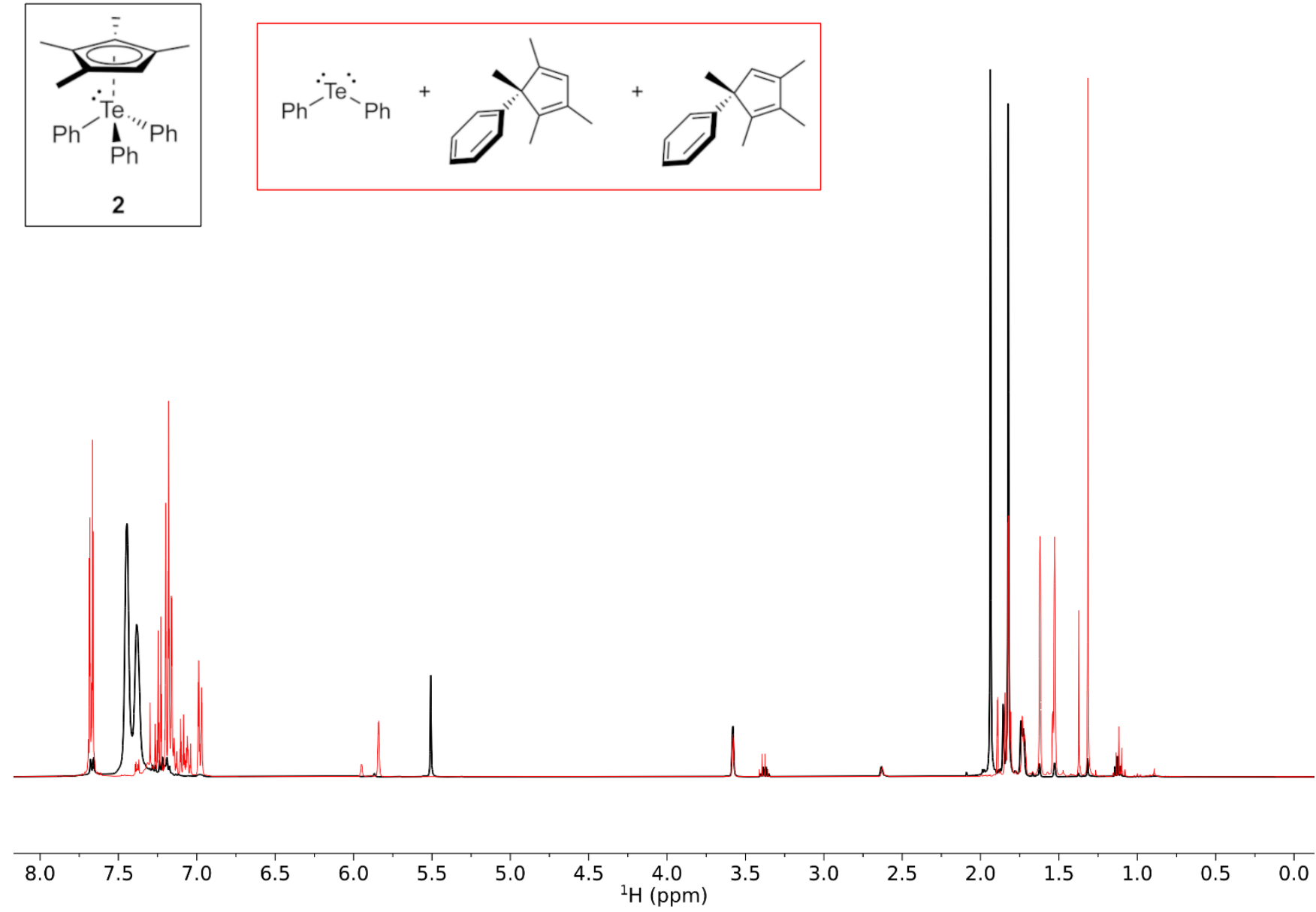

Figure S15. ${ }^{1} \mathrm{H}$ NMR (400 MHz, THF-d8, 238K (black)/298K (red)) of 2. 

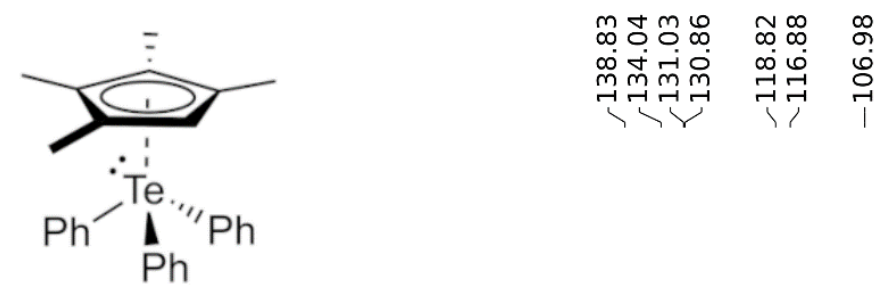

2

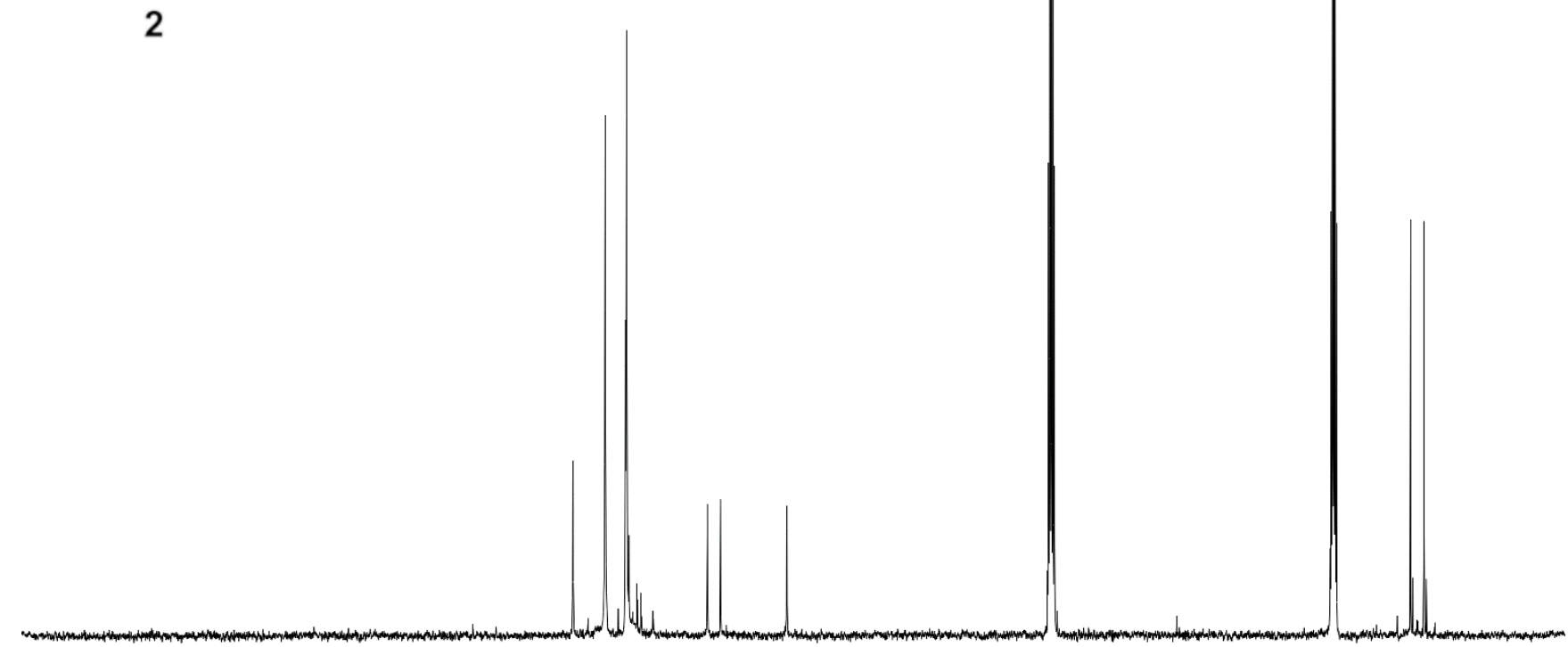

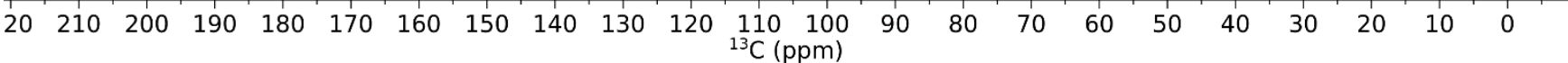

Figure S16. ${ }^{13} \mathrm{C}$ NMR (101 MHz, THF- $\left.d_{8}, 238 \mathrm{~K}\right)$ of 2. 


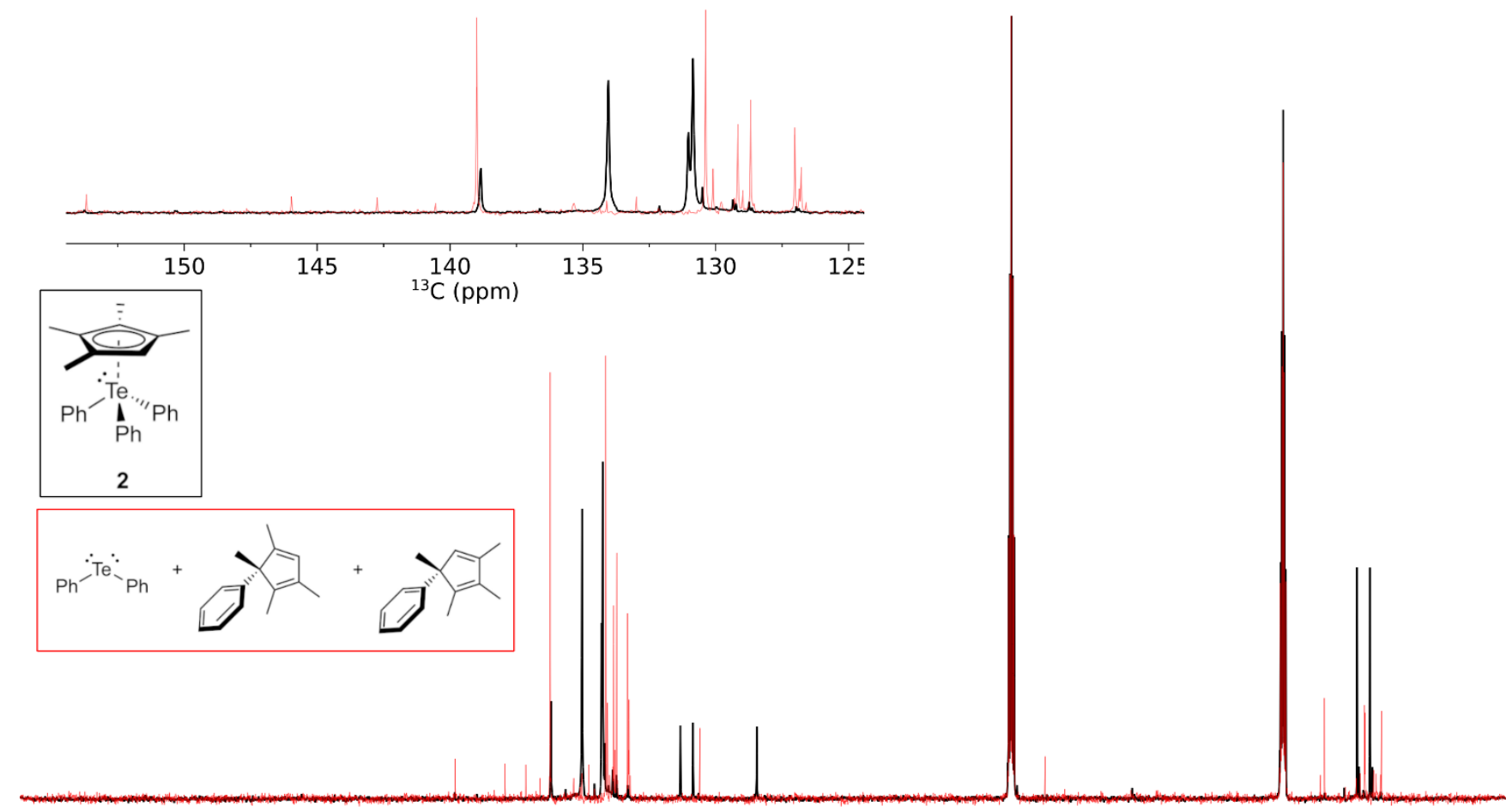

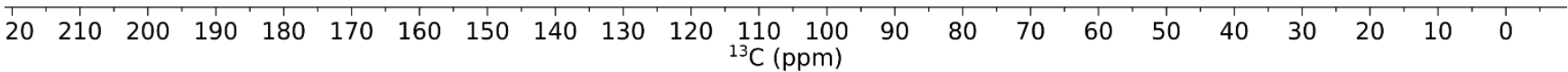

Figure S17. ${ }^{13} \mathrm{C}$ NMR (101 MHz, THF- $d_{8}, 238 \mathrm{~K}$ (black)/298K (red)) of 2. 


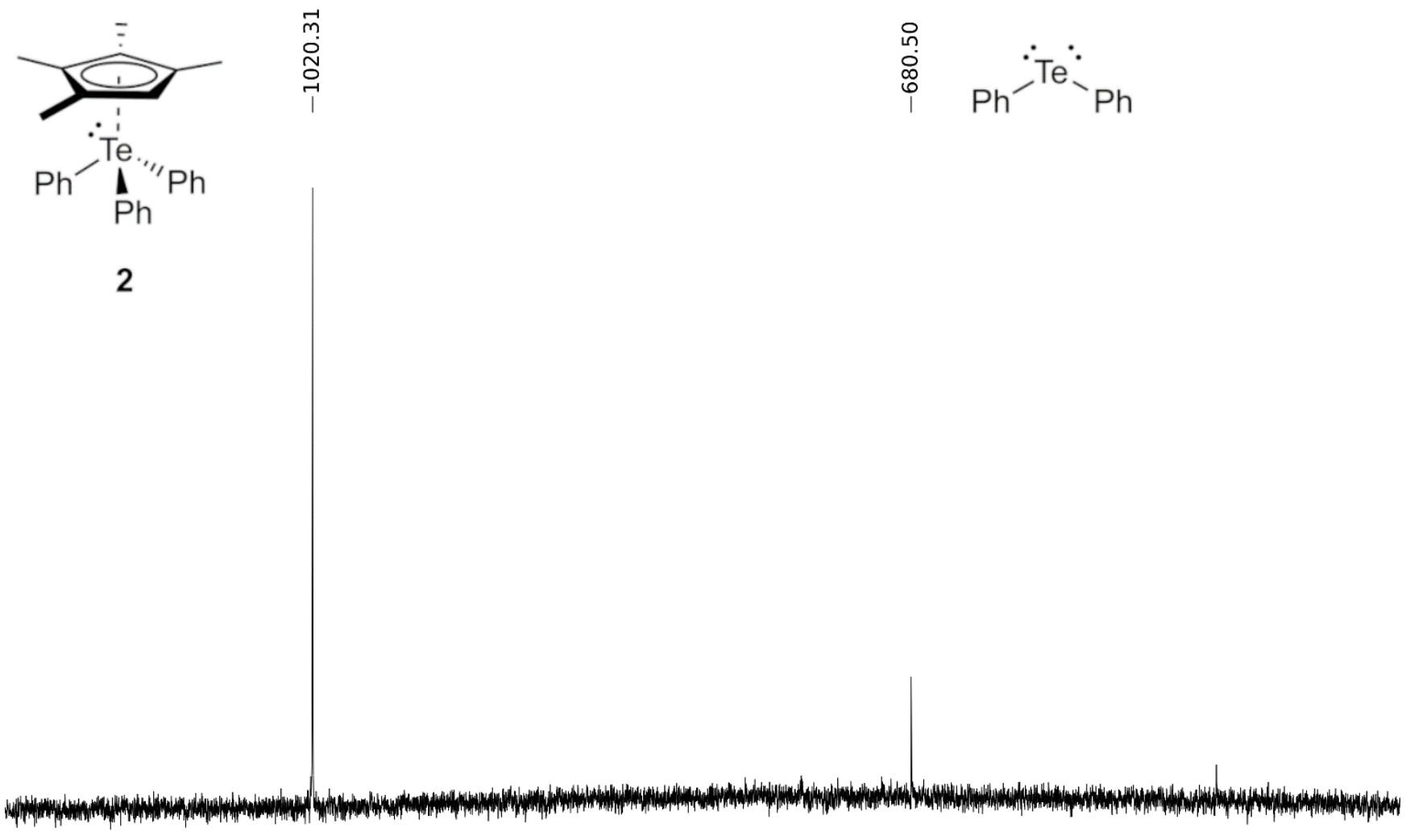

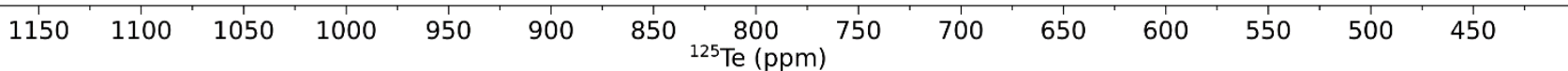

Figure S18. ${ }^{125} \mathrm{Te}$ NMR (126 MHz, THF-d8, 238K) of 2. 

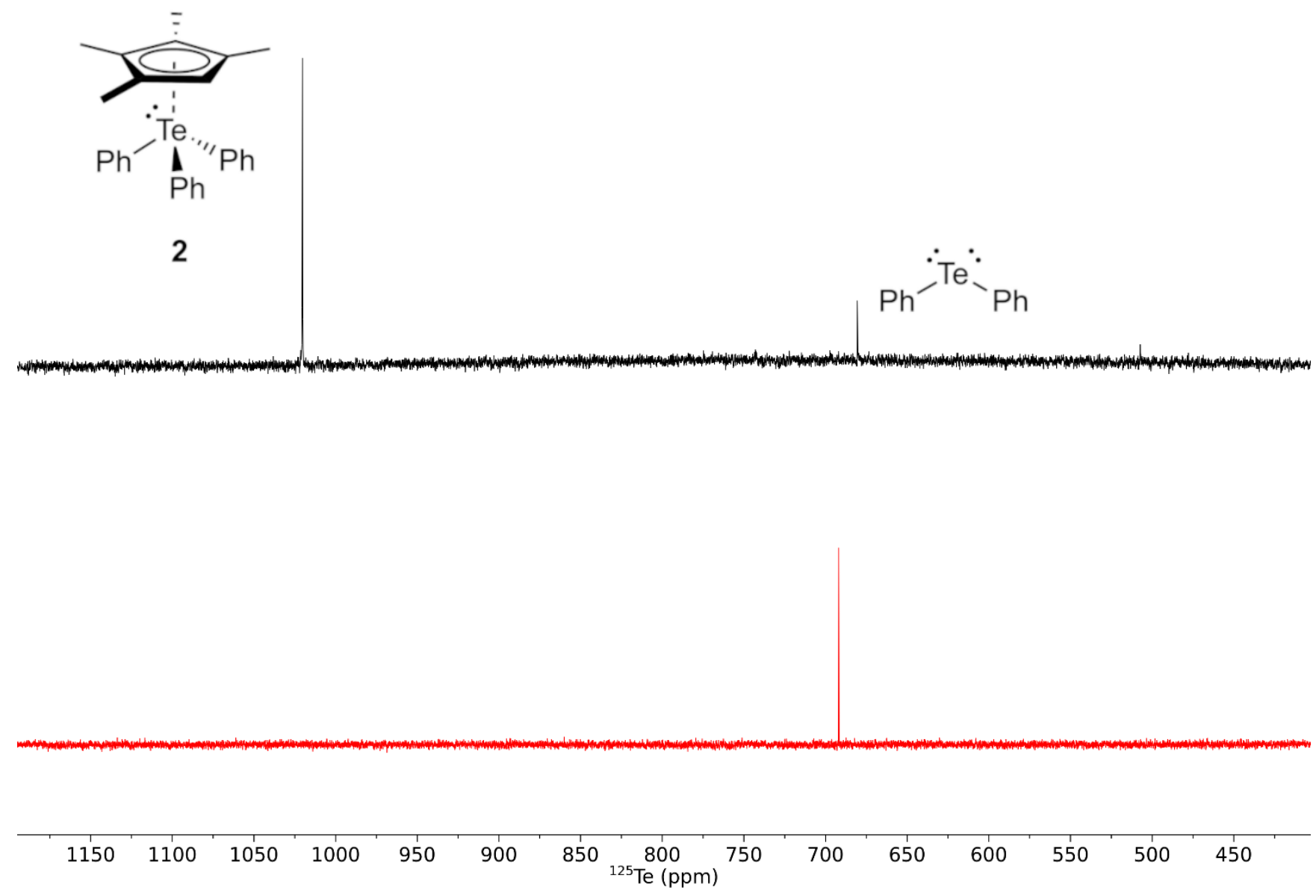

Figure S19. ${ }^{125}$ Te NMR (126 MHz, THF-ds, 238K (black)/298K (red)) of 2. 


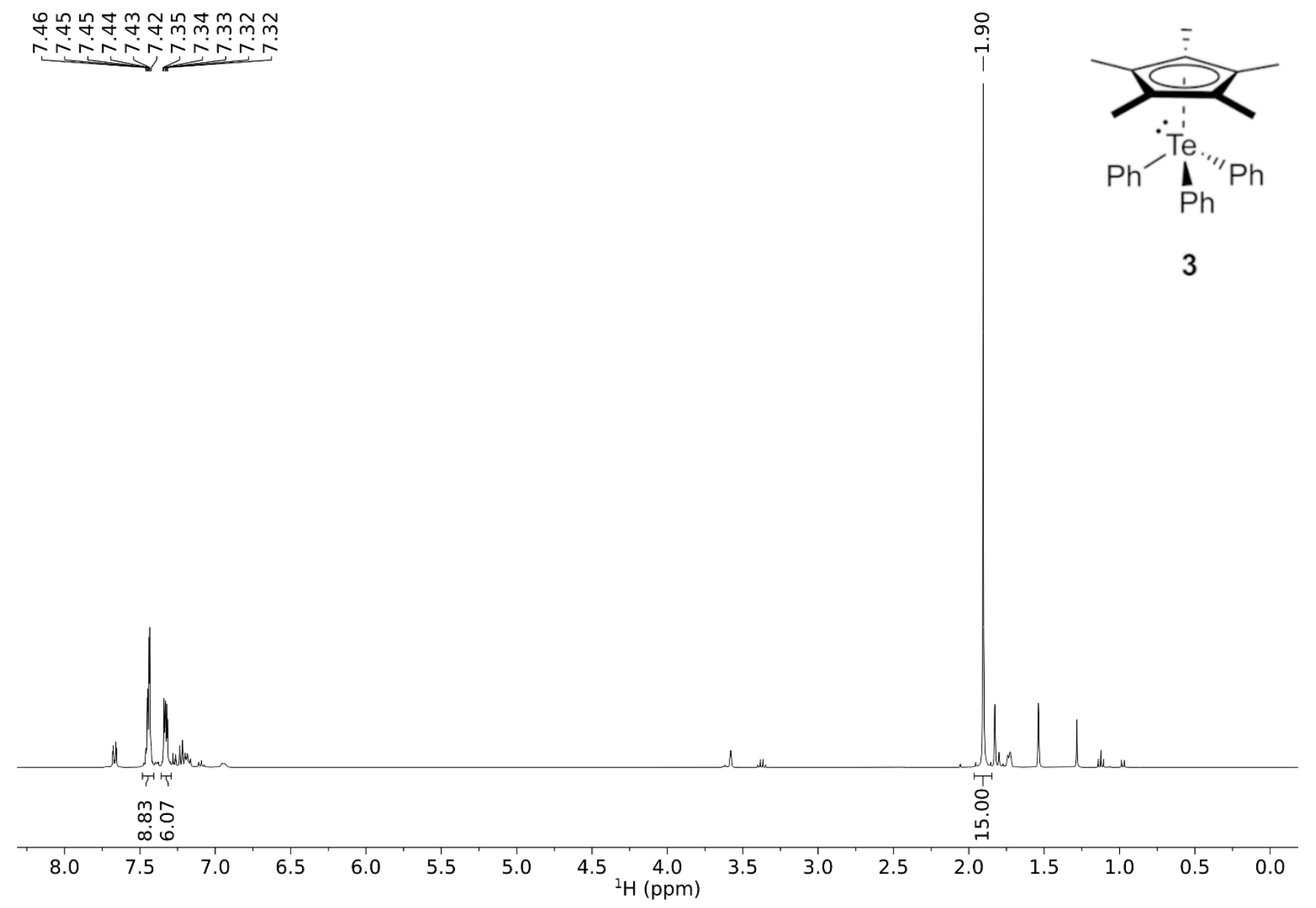

Figure S20. ${ }^{1} \mathrm{H}$ NMR (400 MHz, THF- $\left.d_{8}, 238 \mathrm{~K}\right)$ spectrum of 3. 

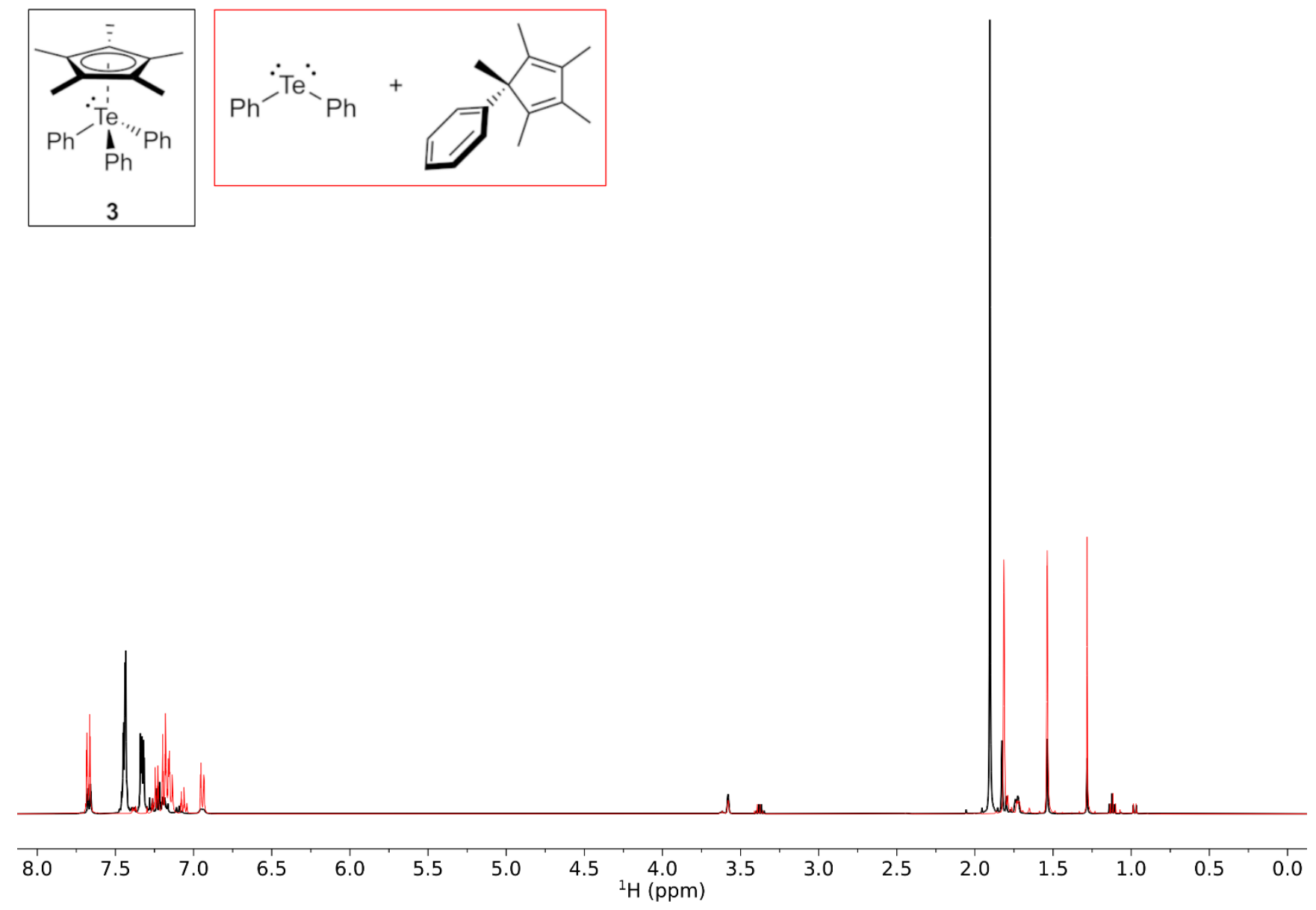

Figure S21. ${ }^{1} \mathrm{H}$ NMR (400 MHz, THF- $d_{8}, 238 \mathrm{~K}$ (black)/298K (red)) spectrum of 3. 


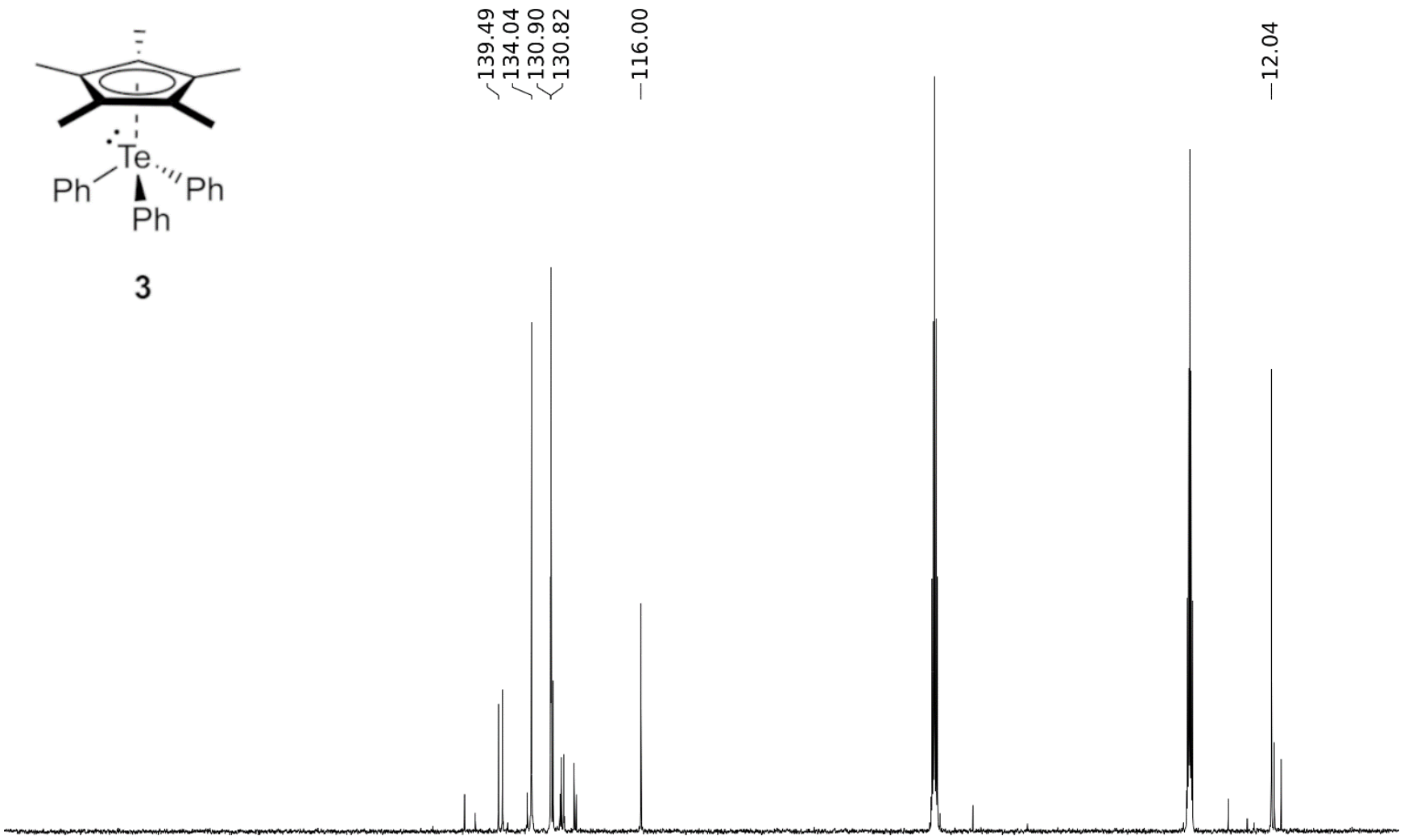

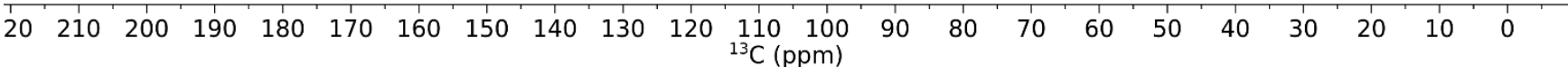

Figure S22. ${ }^{13} \mathrm{C}$ NMR $\left(101 \mathrm{MHz}, \mathrm{THF}-d_{8}, 238 \mathrm{~K}\right)$ spectrum of 3. 


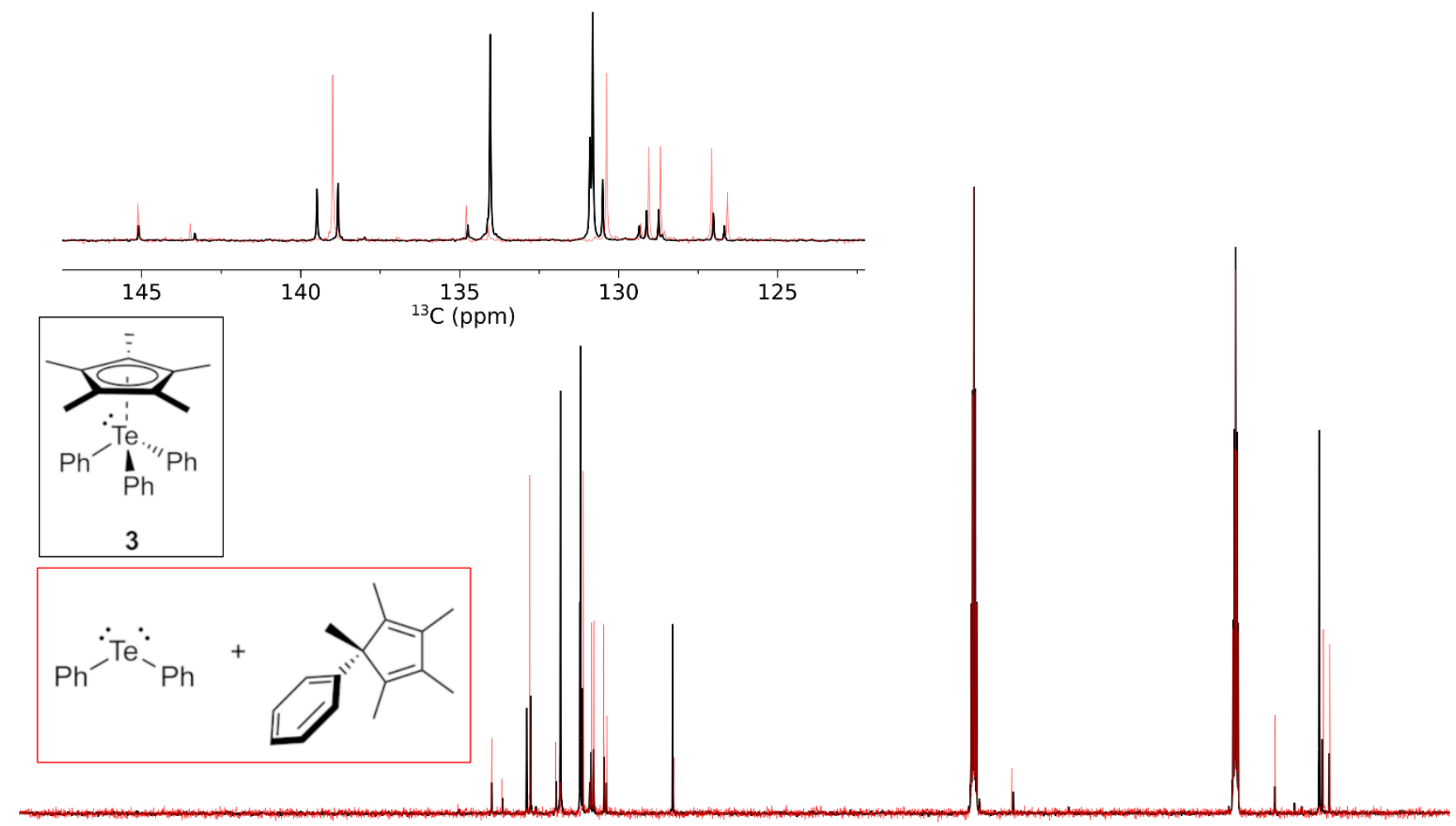

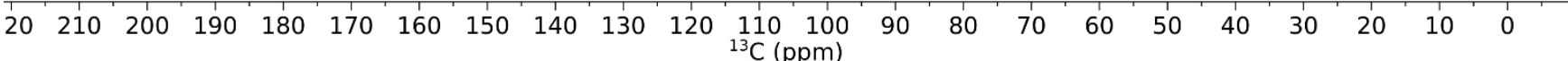

Figure S23. ${ }^{13} \mathrm{C}$ NMR $\left(101 \mathrm{MHz}, \mathrm{THF}-d_{8}, 238 \mathrm{~K}\right.$ (black)/298K (red)) spectrum of 3. 


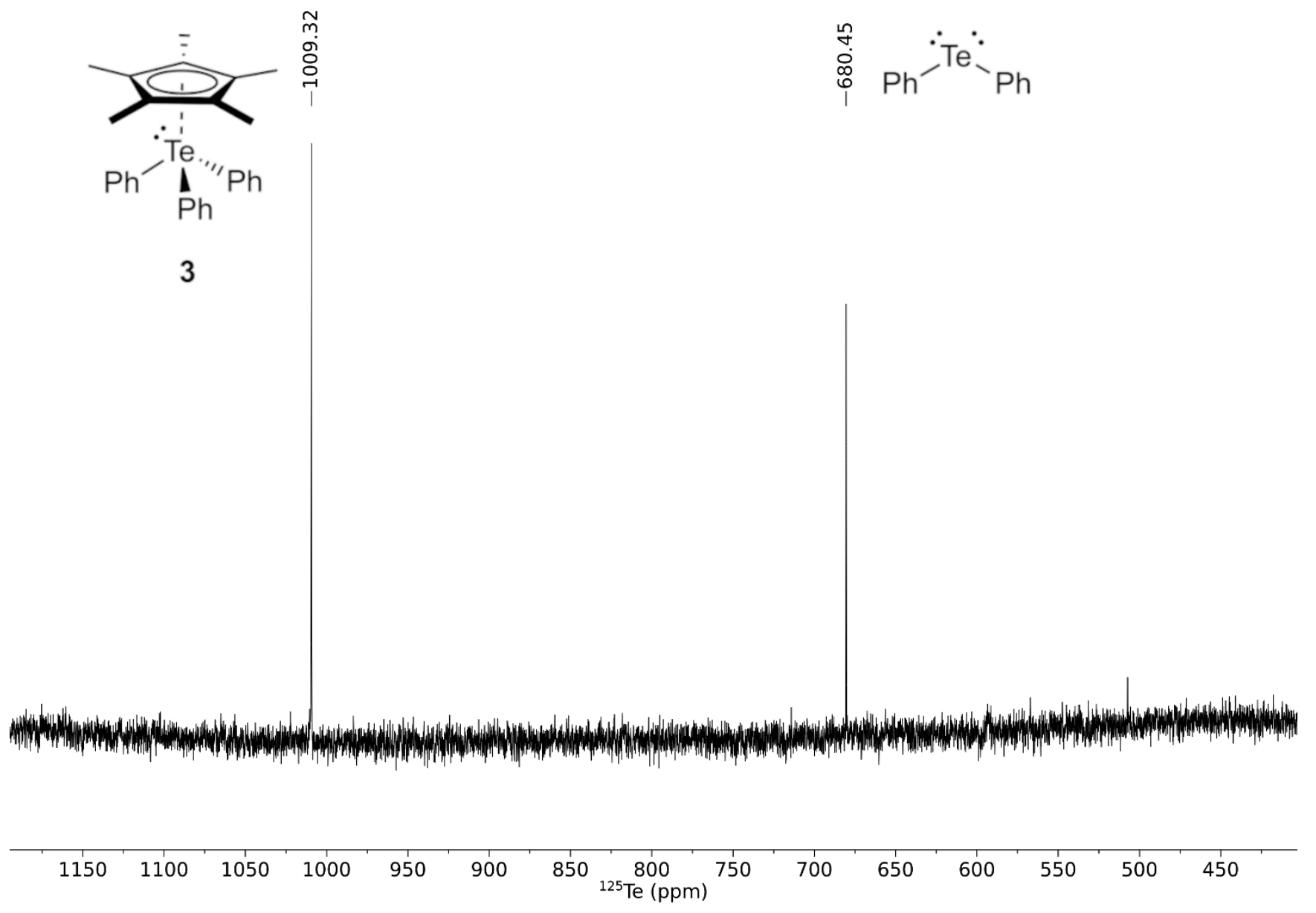

Figure S24. ${ }^{125} \mathrm{Te}$ NMR (126 MHz, THF- $\left.d_{8}, 238 \mathrm{~K}\right)$ spectrum of 3. 

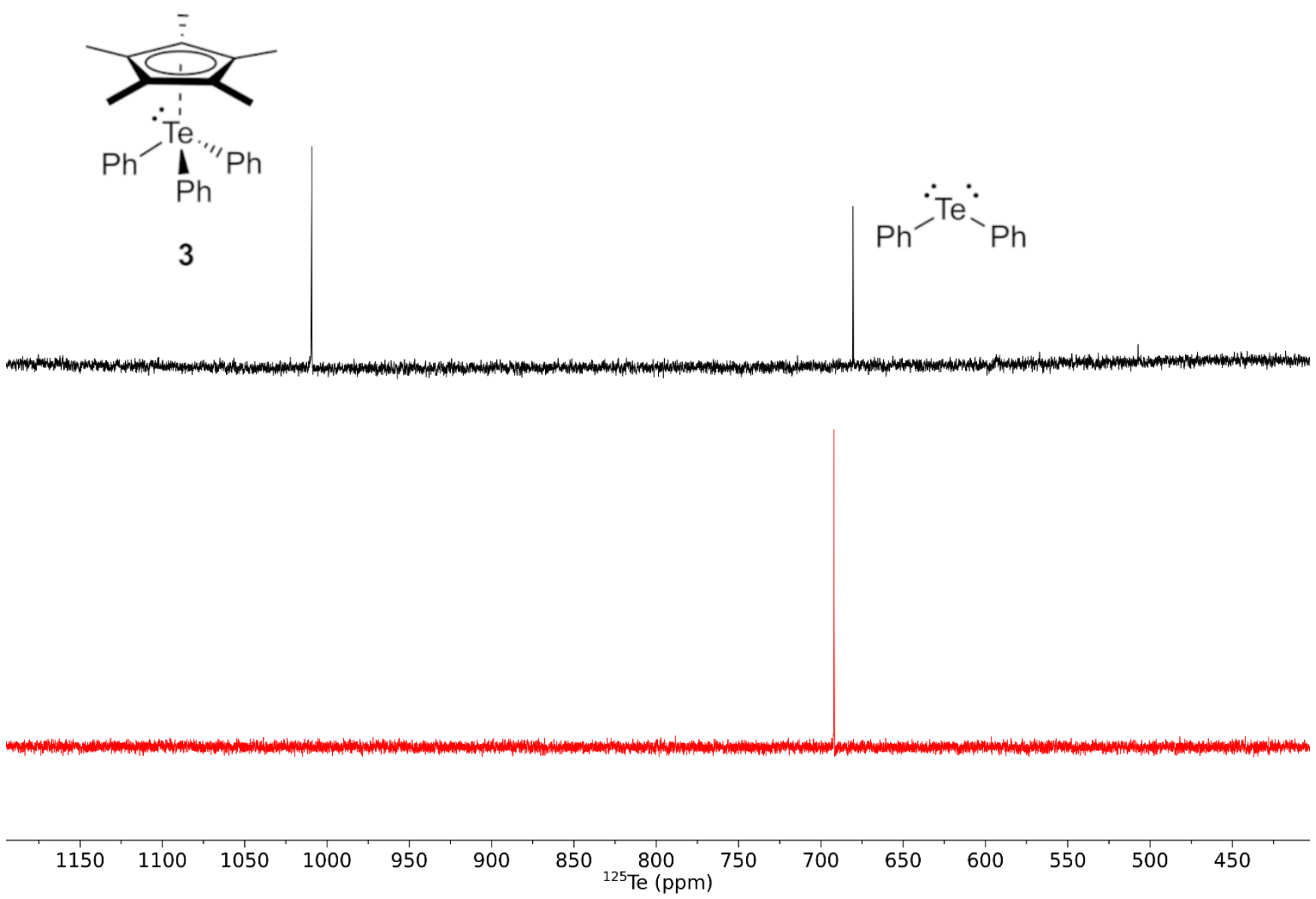

Figure S25. ${ }^{125} \mathrm{Te}$ NMR (126 MHz, THF- $d_{8}, 238 \mathrm{~K}$ (black)/298K (red)) spectrum of 3. 


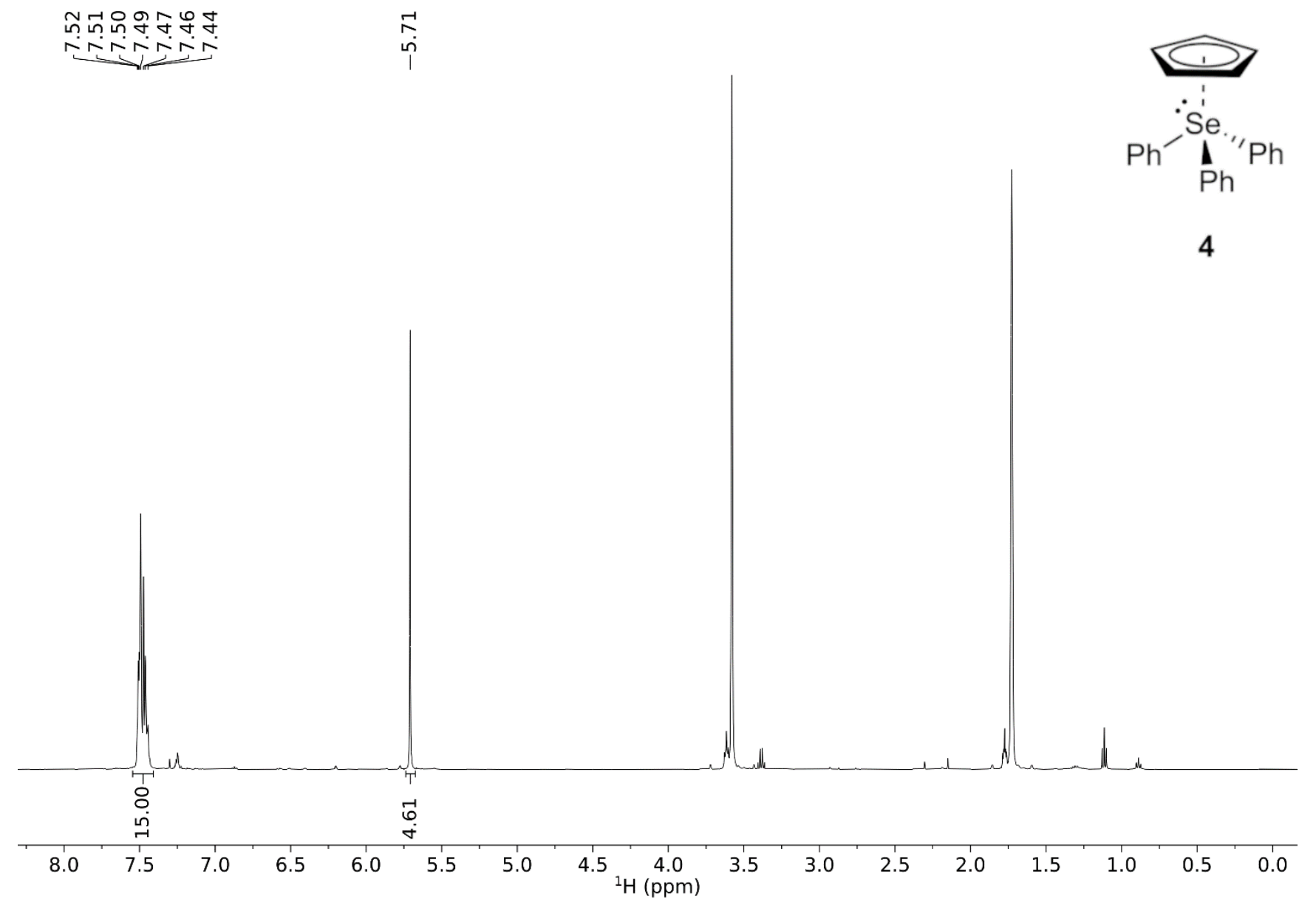

Figure S26. ${ }^{1} \mathrm{H}$ NMR (500 MHz, THF-d8, 298K) spectrum of 4. 


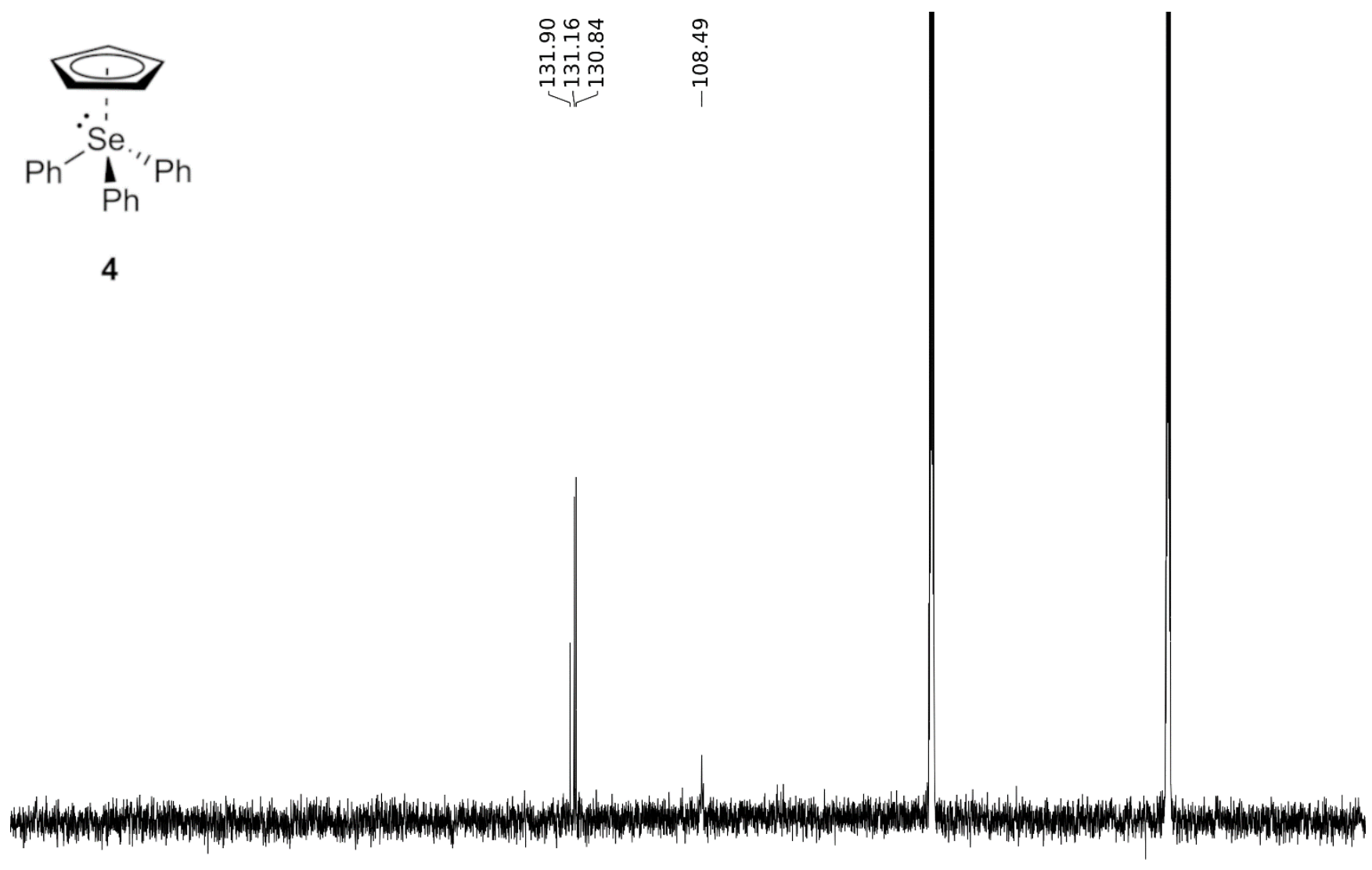

$\begin{array}{lllllllllllllllllllllllllll}30 & 220 & 210 & 200 & 190 & 180 & 170 & 160 & 150 & 140 & 130 & 120 & 110 & 100 & 90 & 80 & 70 & 60 & 50 & 40 & 30 & 20 & 10 & 0 & 13\end{array}$

Figure S27. ${ }^{13} \mathrm{C}$ NMR $\left(126 \mathrm{MHz}, \mathrm{THF}-d_{8}, 298 \mathrm{~K}\right)$ spectrum of 4 . Resonance for $\mathrm{C}_{\mathrm{ipso}}$ not observed after 512 transients. 


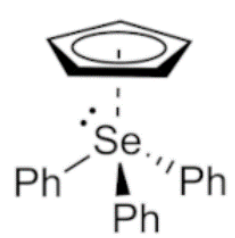

4

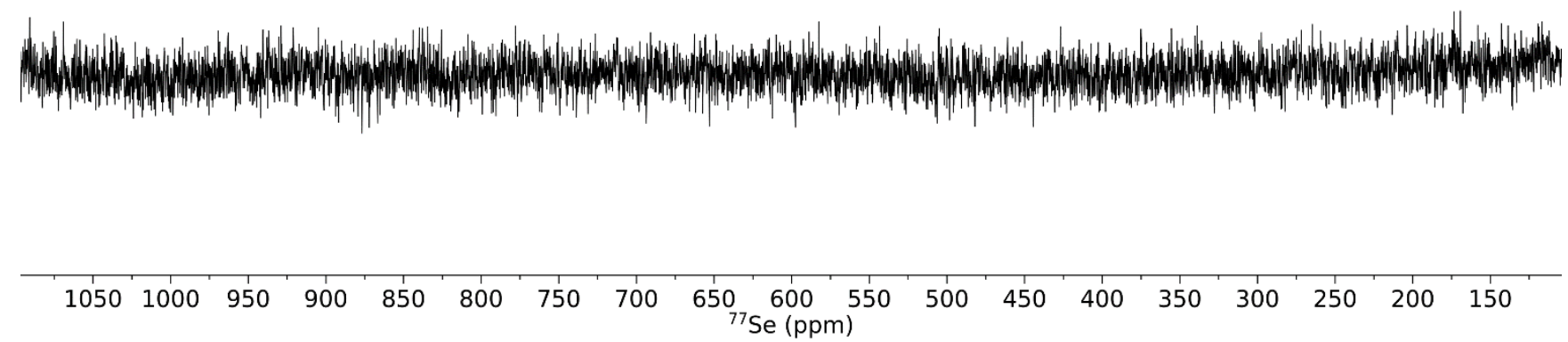

Figure S28. ${ }^{77} \mathrm{Se}$ NMR $\left(76 \mathrm{MHz}, \mathrm{THF}-d_{8}, 298 \mathrm{~K}\right)$ spectrum of 4 . No ${ }^{77}$ Se resonance observed after 1024 transients. 


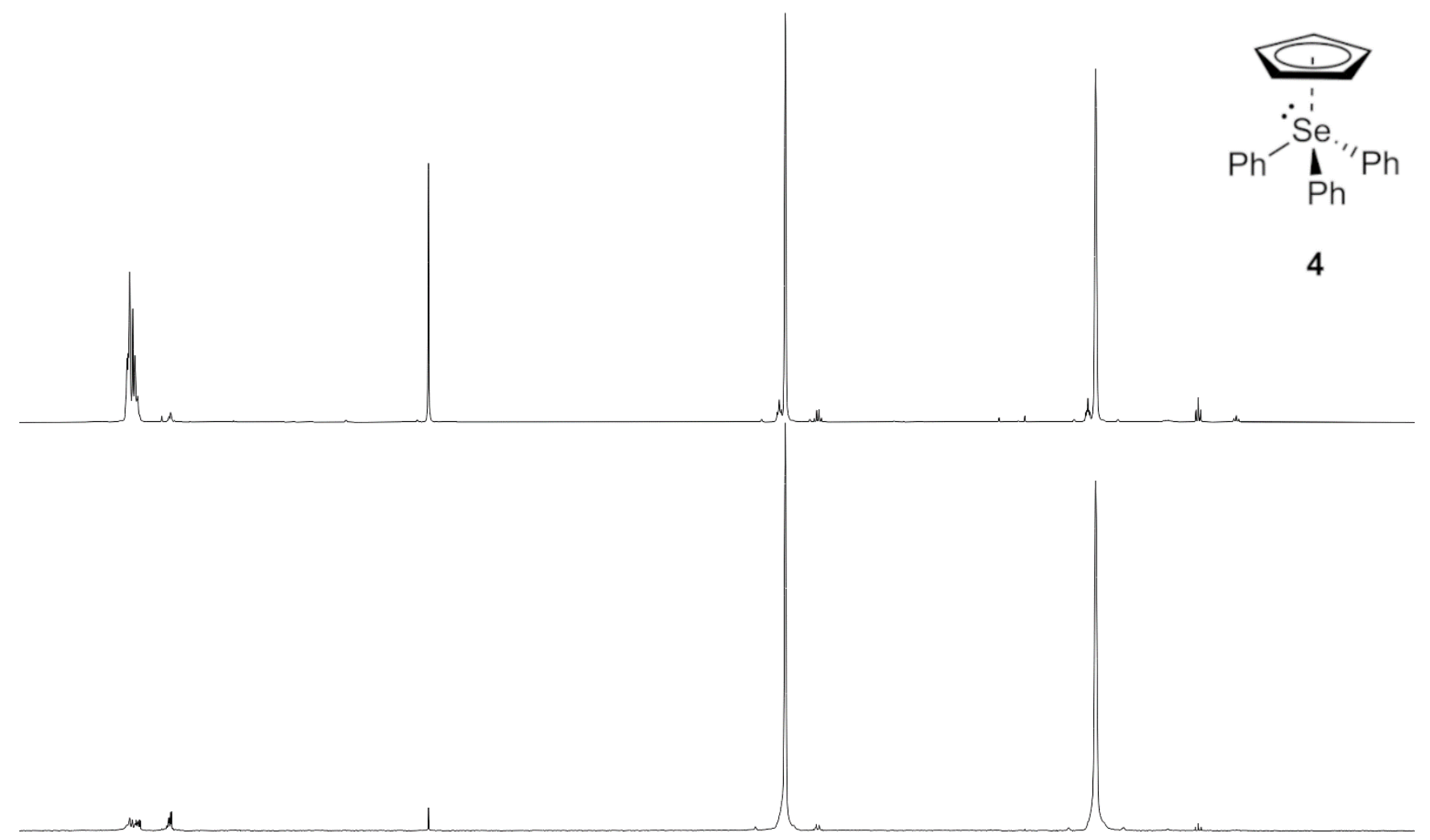

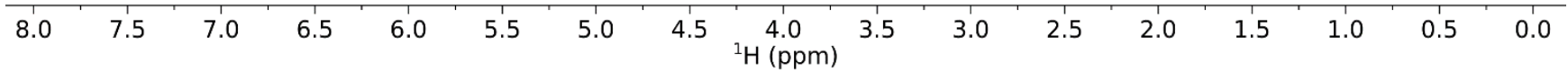

Figure S29. ${ }^{1} \mathrm{H}$ NMR spectrum $\left(500 \mathrm{MHz}, \mathrm{THF}-d_{8}, 298 \mathrm{~K}\right)$ of 4. Top: freshly prepared solution of 4. Bottom: solid sample of $\mathbf{4}$ exposed to air for 4 hours prior to dissolution. 


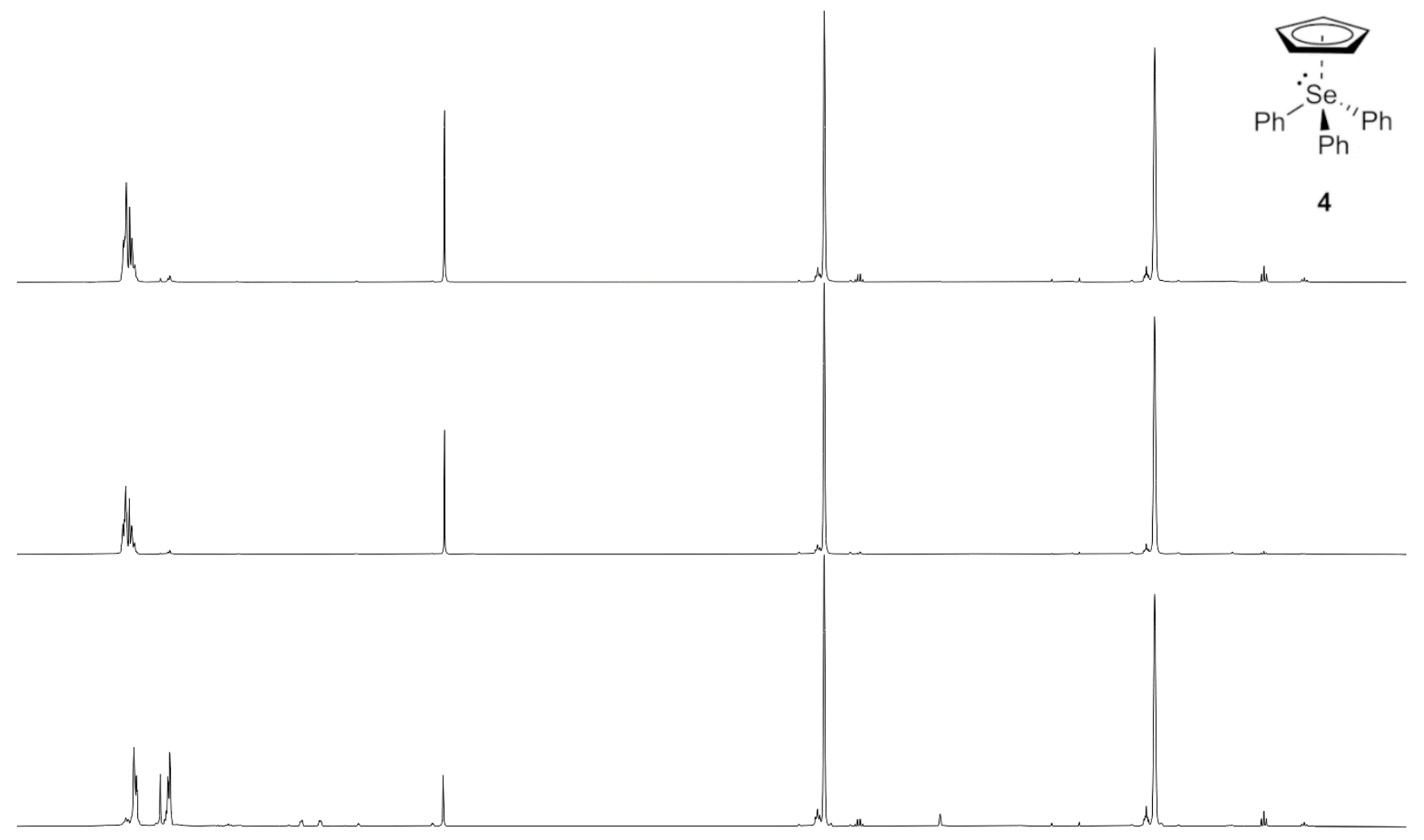

\begin{tabular}{|c|c|c|c|c|c|c|c|c|c|c|c|c|c|c|}
\hline .0 & 7.5 & 7.0 & 6.5 & 6.0 & 5.5 & 5.0 & 4.5 & $\begin{array}{l}4.0 \\
\mathrm{pm})\end{array}$ & 3.5 & 3.0 & 2.5 & 2.0 & 1.5 & 1.0 \\
\hline
\end{tabular}

Figure S30. ${ }^{1} \mathrm{H}$ NMR spectrum $\left(500 \mathrm{MHz}, \mathrm{THF}-d_{8}, 298 \mathrm{~K}\right)$ of 4. Top: freshly prepared solution of 4. Middle: solid sample of $\mathbf{4}$ stored at room temperature in a sealed, nitrogen filled $\mathrm{J}$ Young tube for 24 hours before dissolution. Bottom: solution of $\mathbf{4}$ stored at room temperature in a sealed, nitrogen filled $\mathbf{J}$ Young tube for 24 hours before analysis. 
웜

$\stackrel{\substack{+i}}{+\infty}$

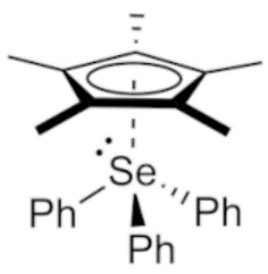

5

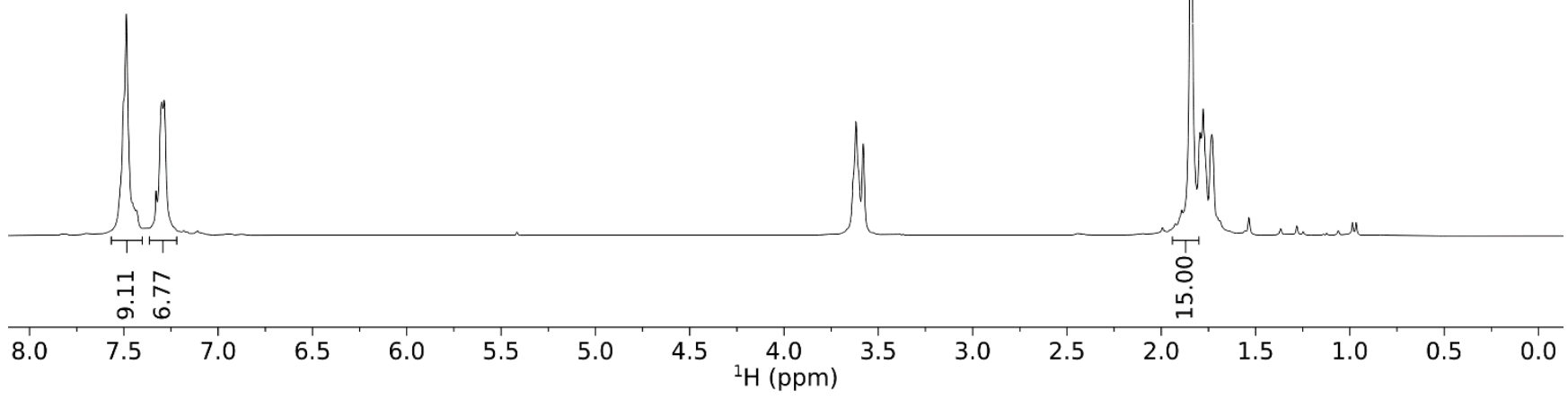

Figure S31. ${ }^{1} \mathrm{H}$ NMR (400 MHz, THF- $\left.d_{8}, 238 \mathrm{~K}\right)$ spectrum of 5. 


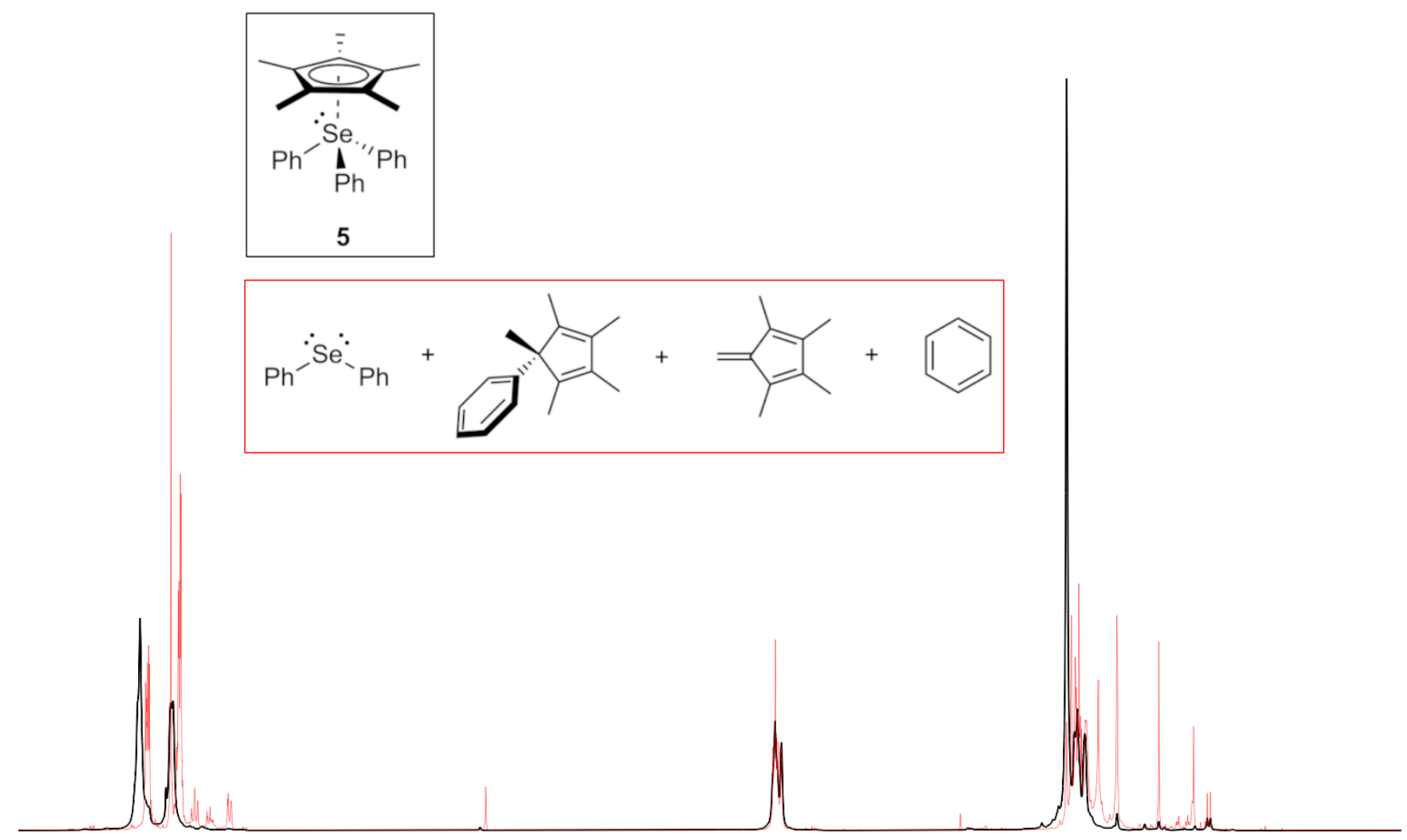

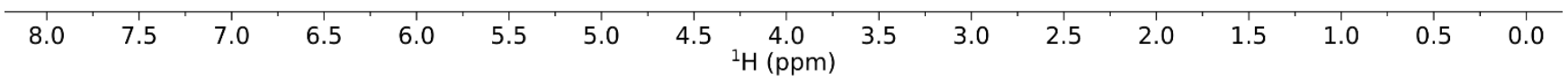

Figure S32. ${ }^{1} \mathrm{H}$ NMR (400 MHz, THF- $d_{8}, 238 \mathrm{~K}$ (black)/298K (red)) spectrum of 5. 


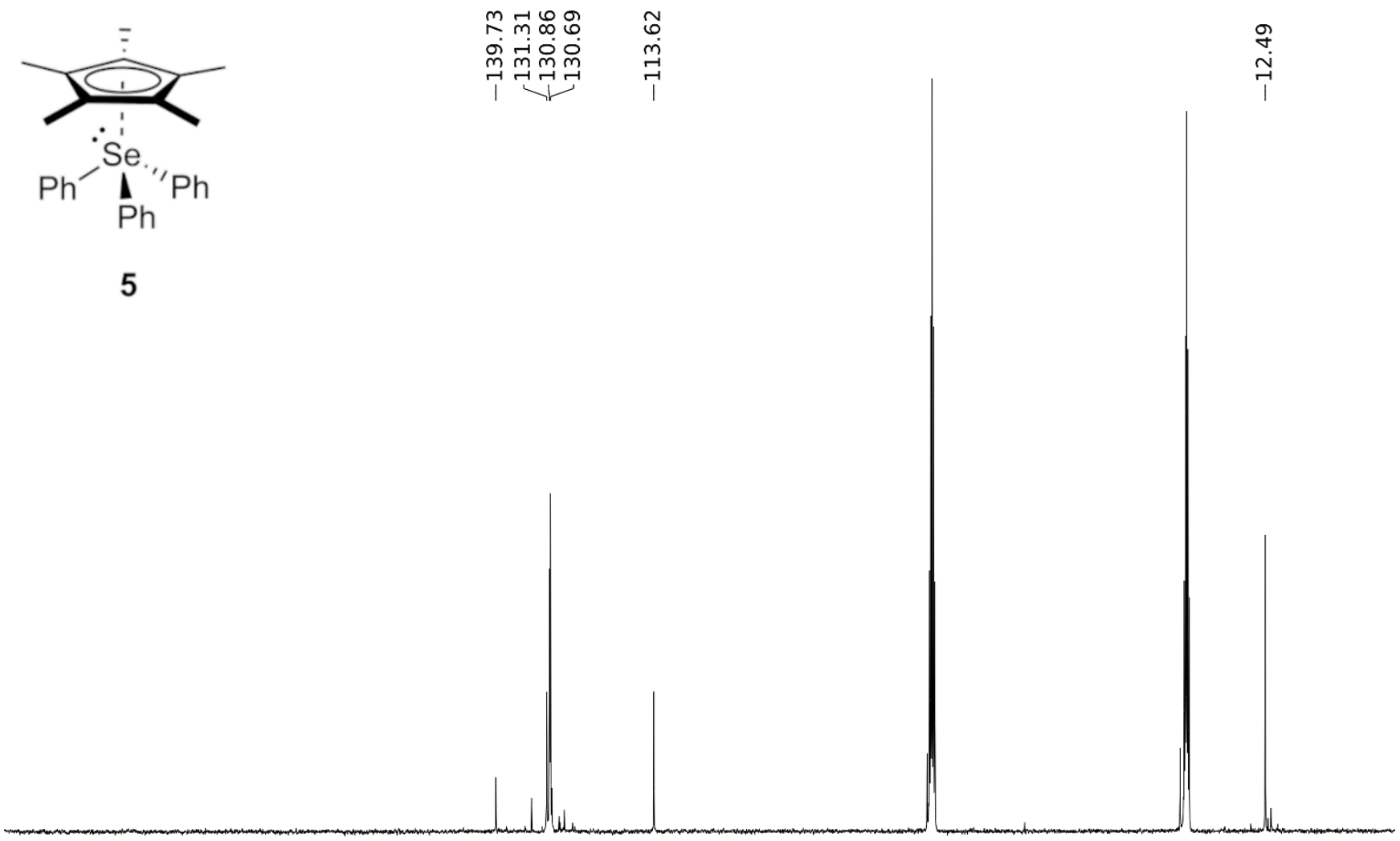

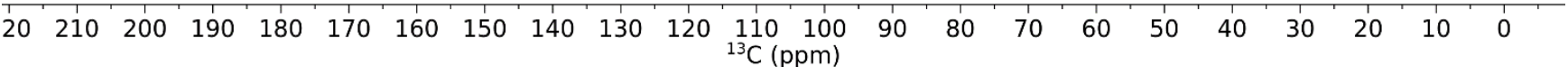

Figure S33. ${ }^{13} \mathrm{C}$ NMR $\left(101 \mathrm{MHz}, \mathrm{THF}-d_{8}, 238 \mathrm{~K}\right)$ spectrum of 5. 


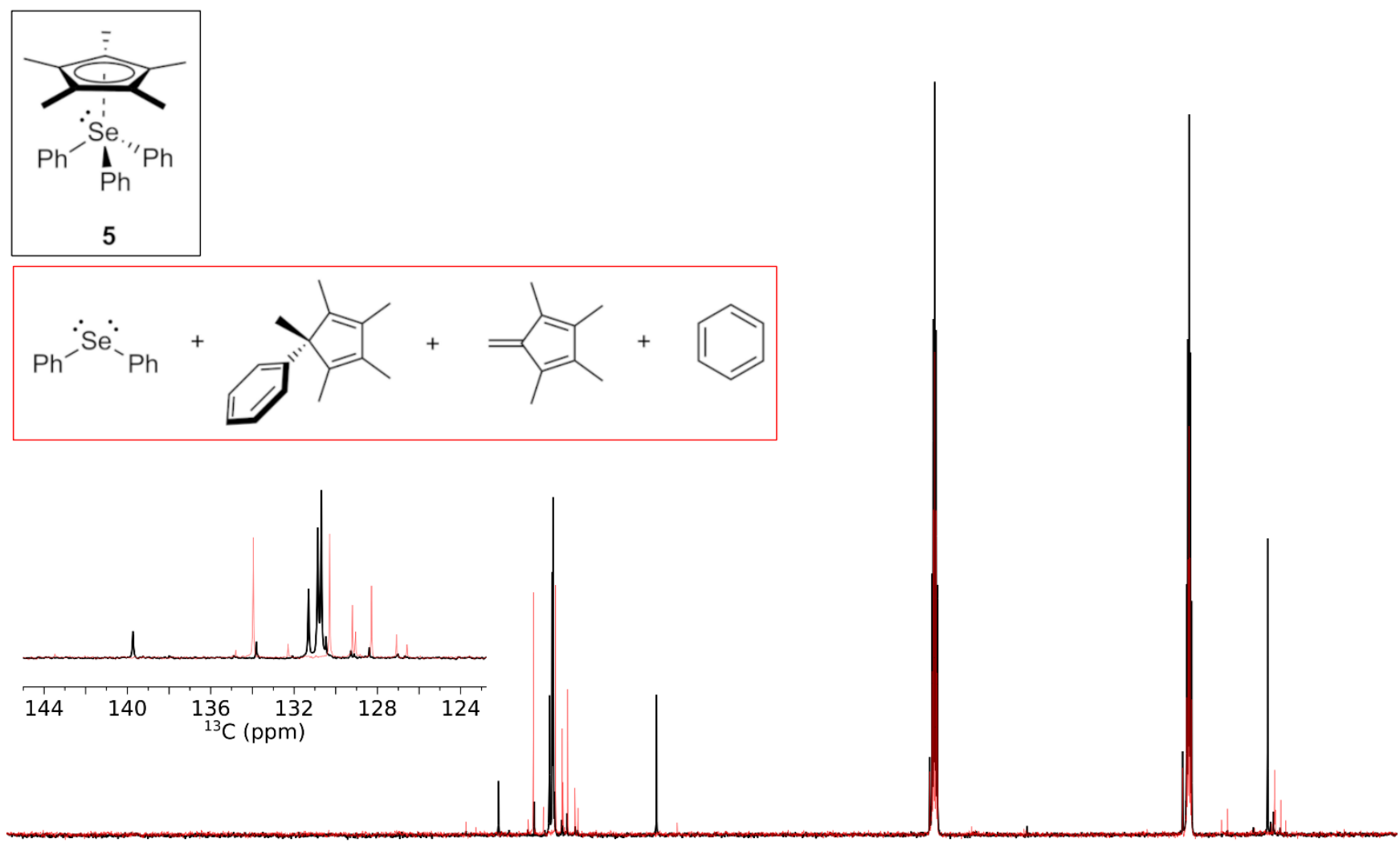

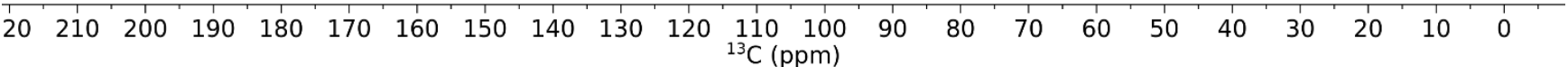

Figure S34. ${ }^{13} \mathrm{C}$ NMR $\left(101 \mathrm{MHz}, \mathrm{THF}-d_{8}, 238 \mathrm{~K}\right.$ (black)/298K (red)) spectrum of 5. 


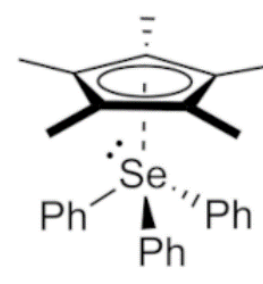

5

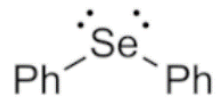

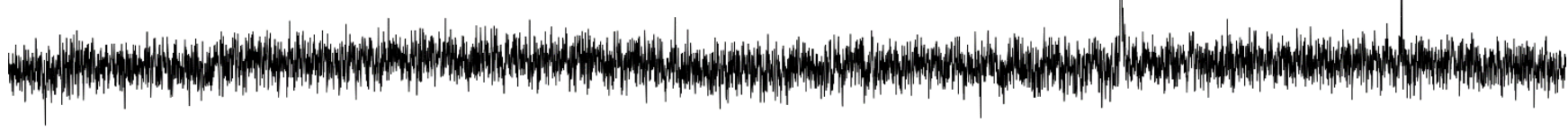

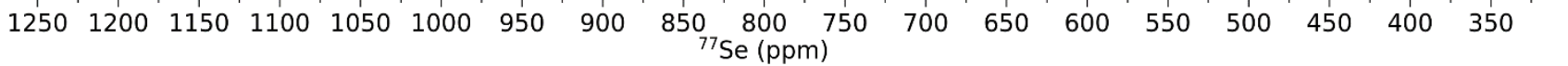

Figure S35. ${ }^{77} \mathrm{Se}$ NMR (76 MHz, THF- $\left.d_{8}, 238 \mathrm{~K}\right)$ spectrum of 5. 

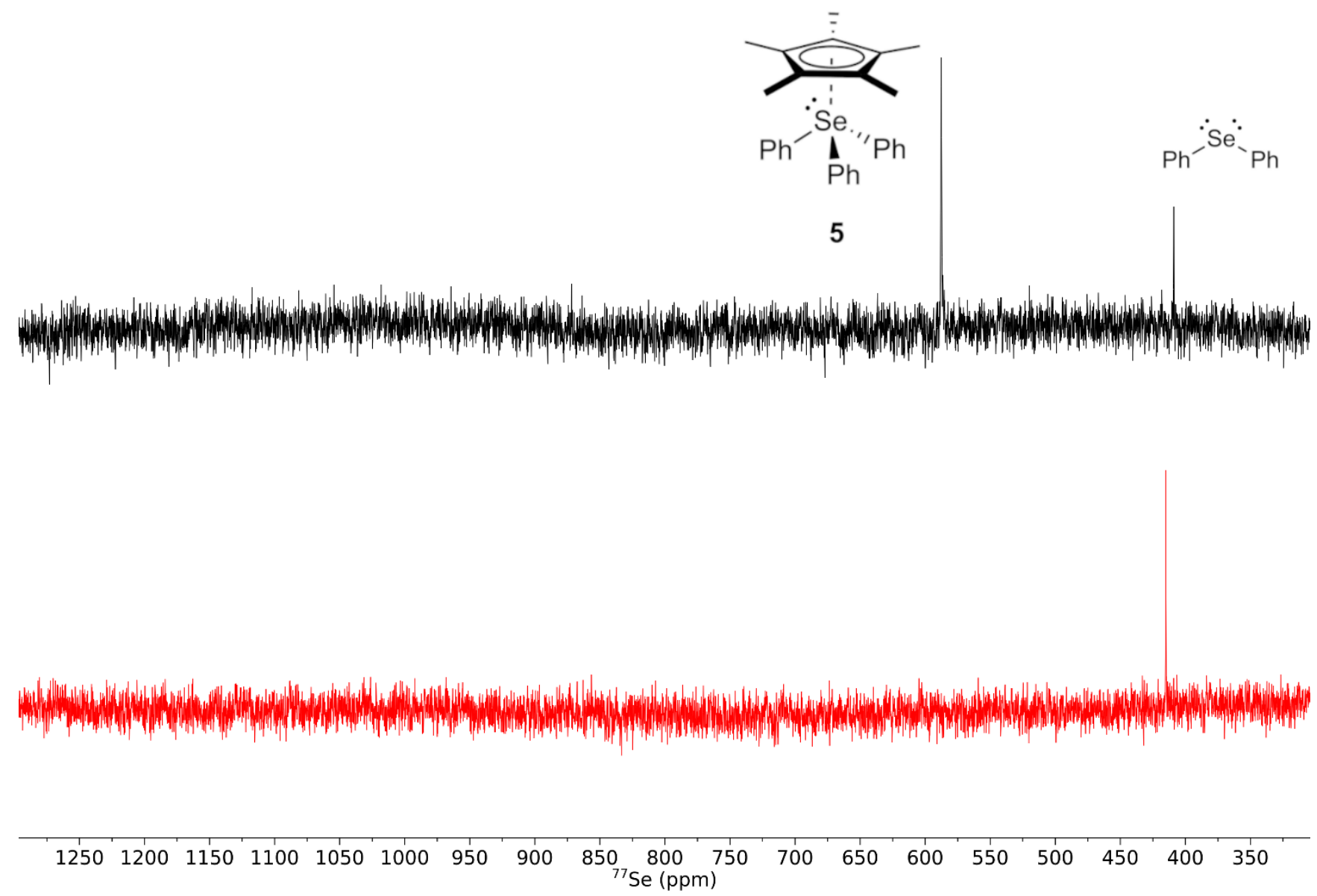

Figure S36. ${ }^{77} \mathrm{Se}$ NMR (76 MHz, THF- $d_{8}, 238 \mathrm{~K}$ (black)/298K (red)) spectrum of 5. 


\section{X-ray Crystallography Details}

General Considerations:

Single crystals of $[\mathrm{Cp}]\left[\mathrm{TePh}_{3}\right](\mathbf{1}),\left[\mathrm{Cp}^{\mathrm{Me} 4}\right]\left[\mathrm{TePh}_{3}\right](\mathbf{2}),\left[\mathrm{Cp}^{*}\right]\left[\mathrm{TePh}_{3}\right](\mathbf{3}),[\mathrm{Cp}]\left[\mathrm{SePh}_{3}\right](\mathbf{4}),\left[\mathrm{Cp}^{*}\right]\left[\mathrm{SePh}_{3}\right]$ (5), $\mathrm{Ph}_{2} \mathrm{Te} \cdot \mathrm{W}(\mathrm{CO})_{5}$, and $\mathrm{Ph}_{3} \mathrm{TeCl}$ were coated in polybutenes and quickly transferred to the goniometer head of a Bruker Quest diffractometer with a fixed chi angle, a sealed tube fine focus X-ray source, a single crystal curved graphite incident beam monochromator, a PhotonII area detector and an Oxford Cryosystems low temperature device. Examination and data collection were performed with Mo Ka radiation $(\lambda=0.71073 \AA)$ at $150 \mathrm{~K}$. Crystals of compounds $2-5$ were handled at $-35^{\circ} \mathrm{C}$ up until being loaded onto the goniometer head.

Data were collected, reflections were indexed and processed, and the files scaled and corrected for absorption using APEX3. ${ }^{6}$ The space groups were assigned using XPREP within the SHELXTL suite of programs ${ }^{7,8}$ and the structures solved by direct methods using SHELXS $^{8}$ and refined by full matrix least squares against $\mathrm{F}^{2}$ with all reflections using SHELXL2018 ${ }^{9,10}$ and the graphical interface ShelXle. ${ }^{11} \mathrm{H}$ atoms attached to carbon atoms were positioned geometrically and constrained to ride on their parent atoms. $\mathrm{C}-\mathrm{H}$ bond distances were constrained to $0.95 \AA$ for aromatic moieties, and to $0.98 \AA$ for $\mathrm{CH}_{3}$ moieties. Methyl $\mathrm{CH}_{3} \mathrm{H}$ atoms were allowed to rotate but not to tip to best fit the experimental electron density. Additional data collection and refinement details, including description of disorder (where present), are included below. Complete crystallographic data, in CIF format, have been deposited with the Cambridge Crystallographic Data Centre. CCDC 2111000-2111006 contain the supplementary crystallographic data for this paper. These data can be obtained free of charge from The Cambridge Crystallographic Data Centre via www.ccdc.cam.ac.uk/data_request/cif.

Additional Considerations:

$[\mathrm{Cp}]\left[\mathrm{TePh}_{3}\right](\mathbf{1})$

The cyclopentadienyl ring was found to be disordered about a three-fold axis at the crystallographic $c$ axis. Occupancies for disordered atoms were constrained to $1 / 3,1,2$ distances within the ring were restricted to be similar within a standard deviation of $0.015 \AA$, and $U^{\mathrm{ij}}$ components of ADPs for disordered atoms closer than $2.0 \AA$ were restrained to be similar within a standard deviation of $0.01 \AA^{2}$.

$[\mathrm{Cp}]\left[\mathrm{SePh}_{3}\right](\mathbf{4})$

The cyclopentadienyl ring was found to be disordered about a three-fold axis at the crystallographic $c$ axis. Occupancies for disordered atoms were constrained to $1 / 3,1,2$ distances within the ring were restrained to be similar within a standard deviation of $0.01 \AA$, and $\mathrm{U}^{\mathrm{ij}}$ components of ADPs for disordered atoms closer than $2.0 \AA$ were restrained to be similar within a standard deviation of $0.01 \AA^{2}$.

$[\mathrm{Cp} *]\left[\mathrm{SePh}_{3}\right](\mathbf{5})$

The crystal under investigation was found to be non-merohedrally twinned. The orientation matrices for the two components were identified using the program Cell_Now, ${ }^{12}$ with the two components being related by a $180^{\circ}$ rotation around the [101] axis. The exact twin matrix identified by Cell_Now was found to be:

$-0.041-0.0010 .957$

$0.000-1.0000 .000$

$1.043-0.0010 .041$ 
Integration, scaling, and absorption correction was handled as if the data was not twinned. The structure was solved with direct methods using reflections of all components. The structure was refined using reflections of all components with a resolution better than $0.70 \AA$, applying the above twin law within SHELXL, resulting in a BASF value of 0.0377(7). In addition to twinning, one of the phenyl groups was found to be disordered. The 1,2 and 1,3 distances within and between the disordered fragments were restrained to be similar within a standard deviation of $0.02 \AA$ and $0.04 \AA$, respectively. $\mathrm{U}^{\mathrm{ij}}$ components of ADPs for disordered atoms closer to each other than $2.0 \AA$ were restrained to be similar within a standard deviation of $0.03 \AA^{2}$. The ADPs for carbon atoms at the ipso-position within the disordered fragments were constrained to be equal. Occupancy of atoms C39A $>$ C44A and C39B $>$ C44B refined to $0.61(4)$ and $0.39(4)$, respectively.

$\mathrm{Ph}_{2} \mathrm{Te} \cdot \mathrm{W}(\mathrm{CO})_{5}$

The crystal under investigation was found to be pseudo-merohedrally twinned. The program ROTAX ${ }^{13}$ was used to determine that the two twin components were related by a $180.0^{\circ}$ rotation around the 100 direct lattice direction resulting in the twin matrix:

$$
\begin{array}{lll}
1.000 & 0.000 & 0.000 \\
-1.000 & -1.000 & 0.000 \\
0.000 & 0.000 & -1.000
\end{array}
$$

The structure was solved with SHELXS in P1 using direct methods. A missing inversion center was found using ADDSYM in PLATON. ${ }^{14}$ The final structure was solved with SHELXS in P-1 using direct methods and refined using the hklf 4 routine, resulting in a BASF value of 0.5535(4). 
Table S1. Crystal data and structure refinement for 1-3.

\begin{tabular}{|c|c|c|c|}
\hline Compound & 1 & 2 & 3 \\
\hline Empirical Formula & {$\left[\mathrm{C}_{5} \mathrm{H}_{5}\right]\left[\mathrm{C}_{18} \mathrm{H}_{15} \mathrm{Te}\right]$} & {$\left[\mathrm{C}_{9} \mathrm{H}_{13}\right]\left[\mathrm{C}_{18} \mathrm{H}_{15} \mathrm{Te}\right]$} & {$\left[\mathrm{C}_{10} \mathrm{H}_{15}\right]\left[\mathrm{C}_{18} \mathrm{H}_{15} \mathrm{Te}\right]$} \\
\hline Formula Weight & 423.99 & 480.09 & 494.12 \\
\hline Temperature (K) & $150(2)$ & $150(2)$ & $150(2)$ \\
\hline Wavelength $(\AA)$ & 0.71073 & 0.71073 & 0.71073 \\
\hline Crystal System & Trigonal & Orthorhombic & Monoclinic \\
\hline Space Group & $R \overline{3}$ & $P_{\text {Pna } 2_{1}}$ & $P 2_{1} / n$ \\
\hline $\mathrm{a}(\AA)$ & $11.1019(4)$ & $18.4656(6)$ & $8.2522(2)$ \\
\hline $\mathrm{b}(\AA)$ & $11.1019(4)$ & $8.0085(2)$ & $18.3739(5)$ \\
\hline $\mathrm{c}(\AA)$ & $26.0436(9)$ & $15.1907(5)$ & $15.7840(4)$ \\
\hline$\alpha\left({ }^{\circ}\right)$ & 90 & 90 & 90 \\
\hline$\beta\left({ }^{\circ}\right)$ & 90 & 90 & $95.1630(10)$ \\
\hline$\gamma\left({ }^{\circ}\right)$ & 120 & 90 & 90 \\
\hline Volume $\left(\AA^{3}\right)$ & $2779.9(2)$ & $2246.43(12)$ & $2383.54(11)$ \\
\hline Z, Z' & 6 & 4 & 4 \\
\hline Density (calculated, $\mathrm{Mg} / \mathrm{m}^{3}$ ) & 1.520 & 1.420 & 1.377 \\
\hline $\begin{array}{l}\text { Absorption Coefficient } \\
\left(\mathrm{mm}^{-1}\right)\end{array}$ & 1.605 & 1.333 & 1.259 \\
\hline $\mathrm{F}(000)$ & 1260 & 968 & 1000 \\
\hline Crystal Size $(\mathrm{mm})$ & $0.13 \times 0.10 \times 0.05$ & $0.41 \times 0.34 \times 0.30$ & $0.36 \times 0.31 \times 0.21$ \\
\hline $\begin{array}{c}\theta \text { range for data collection } \\
\left({ }^{\circ}\right)\end{array}$ & 2.633 to 33.171 & 3.080 to 33.166 & 2.819 to 33.179 \\
\hline Index Ranges & $\begin{array}{l}-17 \leq \mathrm{h} \leq 17, \\
-17 \leq \mathrm{k} \leq 17, \\
-39 \leq 1 \leq 40\end{array}$ & $\begin{array}{l}-28 \leq \mathrm{h} \leq 27, \\
-12 \leq \mathrm{k} \leq 12, \\
-23 \leq 1 \leq 23\end{array}$ & $\begin{array}{l}-12 \leq \mathrm{h} \leq 12, \\
-28 \leq \mathrm{k} \leq 28 \\
-24 \leq \mathrm{l} \leq 24\end{array}$ \\
\hline Reflections Collected & 42458 & 50626 & 145558 \\
\hline Independent Reflections & $\begin{array}{c}2369 \\
{\left[\mathrm{R}_{\text {int }}=0.059\right]}\end{array}$ & $\begin{array}{c}8558 \\
{\left[\mathrm{R}_{\text {int }}=0.035\right]}\end{array}$ & $\begin{array}{c}9110 \\
{\left[\mathrm{R}_{\text {int }}=0.035\right]}\end{array}$ \\
\hline Completeness to $\theta=25.24^{\circ}$ & $99.6 \%$ & $99.6 \%$ & $99.8 \%$ \\
\hline Absorption Correction & multi-scan & multi-scan & multi-scan \\
\hline Min. and Max. Absorption & 0.670 and 0.747 & 0.678 and 0.747 & 0.691 and 0.747 \\
\hline $\begin{array}{l}\text { Data / Restraints / } \\
\text { Parameters }\end{array}$ & $2369 / 40 / 103$ & $8558 / 1 / 257$ & $9110 / 0 / 267$ \\
\hline Goodness-of-fit on $F^{2}$ & 1.179 & 1.037 & 1.094 \\
\hline Final R Indices [I>2 $\sigma(\mathrm{I})]$ & $\begin{array}{c}\mathrm{R} 1=0.0313 \text { and } \\
\mathrm{wR} 2=0.0551\end{array}$ & $\begin{array}{c}\mathrm{R} 1=0.0183 \text { and } \\
\mathrm{wR} 2=0.0376\end{array}$ & $\begin{array}{c}\mathrm{R} 1=0.0189 \text { and } \\
\mathrm{wR} 2=0.0431\end{array}$ \\
\hline $\mathrm{R}$ indices (all data) & $\begin{array}{c}\mathrm{R} 1=0.0400 \text { and } \\
\mathrm{wR} 2=0.0571\end{array}$ & $\begin{array}{c}\mathrm{R} 1=0.0238 \text { and } \\
\mathrm{wR} 2=0.0397\end{array}$ & $\begin{array}{c}\mathrm{R} 1=0.0246 \text { and } \\
\mathrm{wR} 2=0.0462\end{array}$ \\
\hline $\begin{array}{l}\text { Largest Diff. Peak and Hole } \\
\left(e \times \AA^{-3}\right)\end{array}$ & 0.688 and -1.117 & 0.388 and -0.465 & 0.606 and -0.433 \\
\hline
\end{tabular}


Table S2. Crystal data and structure refinement for $\mathbf{4}$ and $\mathbf{5 .}$

\begin{tabular}{|c|c|c|}
\hline Compound & 4 & 5 \\
\hline Empirical Formula & {$\left[\mathrm{C}_{5} \mathrm{H}_{5}\right]\left[\mathrm{C}_{18} \mathrm{H}_{15} \mathrm{Se}\right]$} & {$\left[\mathrm{C}_{10} \mathrm{H}_{15}\right]\left[\mathrm{C}_{18} \mathrm{H}_{15} \mathrm{Se}\right]$} \\
\hline Formula Weight & 375.35 & 445.48 \\
\hline Temperature (K) & $150(2)$ & $150(2)$ \\
\hline Wavelength $(\AA)$ & 0.71073 & 0.71073 \\
\hline Crystal System & Trigonal & Monoclinic \\
\hline Space Group & $R \overline{3}$ & $P 2_{1} / n$ \\
\hline $\mathrm{a}(\AA)$ & $11.2015(7)$ & $17.7989(12)$ \\
\hline $\mathrm{b}(\AA)$ & $11.2015(7)$ & $15.5809(13)$ \\
\hline c $(\AA)$ & $24.8613(16)$ & $18.2553(12)$ \\
\hline$\alpha\left(^{\circ}\right)$ & 90 & 90 \\
\hline$\beta\left(^{\circ}\right)$ & 90 & $112.433(2)$ \\
\hline$\gamma\left(\left(^{\circ}\right)\right.$ & 120 & 90 \\
\hline Volume $\left(\AA^{3}\right)$ & $2701.5(4)$ & $4679.5(6)$ \\
\hline $\mathrm{Z}, \mathrm{Z}^{\prime}$ & 6 & 8 \\
\hline Density (calculated, $\mathrm{Mg} / \mathrm{m}^{3}$ ) & 1.384 & 1.265 \\
\hline $\begin{array}{l}\text { Absorption Coefficient } \\
\left(\mathrm{mm}^{-1}\right)\end{array}$ & 2.085 & 1.616 \\
\hline $\mathrm{F}(000)$ & 1152 & 1856 \\
\hline Crystal Size (mm) & $0.11 \times 0.06 \times 0.06$ & $0.35 \times 0.27 \times 0.15$ \\
\hline $\begin{array}{l}\theta \text { range for data collection } \\
\qquad\left({ }^{\circ}\right)\end{array}$ & 2.663 to 33.207 & 1.886 to 30.508 \\
\hline Index Ranges & $\begin{array}{c}-17 \leq \mathrm{h} \leq 17 \\
-17 \leq \mathrm{k} \leq 16, \\
-37 \leq \mathrm{l} \leq 38\end{array}$ & $\begin{array}{l}-25 \leq \mathrm{h} \leq 25 \\
-22 \leq \mathrm{k} \leq 22 \\
-24 \leq \mathrm{l} \leq 26\end{array}$ \\
\hline Reflections Collected & 30862 & 144042 \\
\hline Independent Reflections & 2308 & $\begin{array}{c}14274 \\
{\left[\mathrm{R}_{\text {int }}=0.071\right]}\end{array}$ \\
\hline Completeness to $\theta=25.24^{\circ}$ & $99.7 \%$ & $99.6 \%$ \\
\hline Absorption Correction & multi-scan & multi-scan \\
\hline Min. and Max. Absorption & 0.688 and 0.747 & 0.571 and 0.747 \\
\hline $\begin{array}{c}\text { Data / Restraints / } \\
\text { Parameters }\end{array}$ & $2308 / 40 / 103$ & $14274 / 212 / 583$ \\
\hline Goodness-of-fit on $F^{2}$ & 1.009 & 1.074 \\
\hline Final R Indices $[\mathrm{I}>2 \sigma(\mathrm{I})]$ & $\begin{array}{c}\mathrm{R} 1=0.0465 \text { and } \\
\mathrm{wR} 2=0.1063\end{array}$ & $\begin{array}{c}\mathrm{R} 1=0.0592 \text { and } \\
\mathrm{wR} 2=0.1620\end{array}$ \\
\hline $\mathrm{R}$ indices (all data) & $\begin{array}{c}\mathrm{R} 1=0.0924 \text { and } \\
\mathrm{wR} 2=0.1259\end{array}$ & $\begin{array}{c}\mathrm{R} 1=0.0796 \text { and } \\
\mathrm{wR} 2=0.1780\end{array}$ \\
\hline $\begin{array}{l}\text { Largest Diff. Peak and Hole } \\
\left(\mathrm{e} \times \AA^{-3}\right)\end{array}$ & 0.626 and -0.668 & 1.900 and -0.862 \\
\hline
\end{tabular}


Table S3. Crystal data and structure refinement for $\mathrm{Ph}_{2} \mathrm{Te} \cdot \mathrm{W}(\mathrm{CO})_{5}$ and $\mathrm{Ph}_{3} \mathrm{TeCl}$.

\begin{tabular}{|c|c|c|}
\hline Compound & $\mathrm{Ph}_{2} \mathrm{Te} \cdot \mathrm{W}(\mathrm{CO})_{5}$ & $\mathrm{Ph}_{3} \mathrm{TeCl}$ \\
\hline Empirical Formula & $\mathrm{C}_{18} \mathrm{H}_{15} \mathrm{Te} \cdot \mathrm{C}_{5} \mathrm{O}_{5} \mathrm{~W}$ & $\left(\mathrm{C}_{18} \mathrm{H}_{15} \mathrm{ClTe}\right)_{2} \cdot \mathrm{C}_{7} \mathrm{H}_{8}$ \\
\hline Formula Weight & 605.70 & 880.83 \\
\hline Temperature $(\mathrm{K})$ & $150(2)$ & $150(2)$ \\
\hline Wavelength $(\AA)$ & 0.71073 & 0.71073 \\
\hline Crystal System & Triclinic & Triclinic \\
\hline Space Group & $P \overline{1}$ & $P \overline{1}$ \\
\hline $\mathrm{a}(\AA)$ & $13.0097(5)$ & $10.4162(4)$ \\
\hline $\mathrm{b}(\AA)$ & $16.9681(7)$ & $14.4801(5)$ \\
\hline $\mathrm{c}(\AA)$ & $17.4098(7)$ & $14.7923(5)$ \\
\hline$\alpha\left(^{\circ}\right)$ & $93.4258(18)$ & $61.6911(12)$ \\
\hline$\beta\left(^{\circ}\right)$ & $90.0010(18)$ & $73.4882(13)$ \\
\hline$\gamma\left(\left(^{\circ}\right)\right.$ & $112.4982(17)$ & $88.8005(13)$ \\
\hline Volume $\left(\AA^{3}\right)$ & $3543.3(2)$ & $1866.05(12)$ \\
\hline $\mathrm{Z}, \mathrm{Z}^{\prime}$ & 8 & 2 \\
\hline Density (calculated, $\mathrm{Mg} / \mathrm{m}^{3}$ ) & 2.271 & 1.568 \\
\hline $\begin{array}{l}\text { Absorption Coefficient } \\
\left(\mathrm{mm}^{-1}\right)\end{array}$ & 8.156 & 1.736 \\
\hline $\mathrm{F}(000)$ & 2224 & 868 \\
\hline Crystal Size (mm) & $0.29 \times 0.12 \times 0.10$ & $0.36 \times 0.29 \times 0.27$ \\
\hline $\begin{array}{l}\theta \text { range for data collection } \\
\left({ }^{\circ}\right)\end{array}$ & 2.037 to 33.188 & 2.437 to 33.185 \\
\hline Index Ranges & $\begin{array}{l}-20 \leq \mathrm{h} \leq 19, \\
-26 \leq \mathrm{k} \leq 26, \\
-26 \leq \mathrm{l} \leq 26\end{array}$ & $\begin{array}{l}-16 \leq \mathrm{h} \leq 16, \\
-22 \leq \mathrm{k} \leq 22, \\
-22 \leq \mathrm{l} \leq 22\end{array}$ \\
\hline Reflections Collected & 201990 & 92084 \\
\hline Independent Reflections & $\begin{array}{c}27030 \\
{\left[\mathrm{R}_{\text {int }}=0.047\right]}\end{array}$ & $\begin{array}{c}14218 \\
{\left[\mathrm{R}_{\text {int }}=0.037\right]}\end{array}$ \\
\hline Completeness to $\theta=25.24^{\circ}$ & $99.9 \%$ & $99.7 \%$ \\
\hline Absorption Correction & multi-scan & multi-scan \\
\hline Min. and Max. Absorption & 0.471 and 0.747 & 0.653 and 0.747 \\
\hline $\begin{array}{c}\text { Data / Restraints / } \\
\text { Parameters }\end{array}$ & $27030 / 0 / 866$ & $14218 / 0 / 425$ \\
\hline Goodness-of-fit on $F^{2}$ & 1.027 & 1.040 \\
\hline Final R Indices $[\mathrm{I}>2 \sigma(\mathrm{I})]$ & $\begin{array}{c}\mathrm{R} 1=0.0262 \text { and } \\
\mathrm{wR} 2=0.0479\end{array}$ & $\begin{array}{c}\mathrm{R} 1=0.0205 \text { and } \\
\mathrm{wR} 2=0.0411\end{array}$ \\
\hline $\mathrm{R}$ indices (all data) & $\begin{array}{c}\mathrm{R} 1=0.0356 \text { and } \\
\mathrm{wR} 2=0.0511\end{array}$ & $\begin{array}{c}\mathrm{R} 1=0.0274 \text { and } \\
\mathrm{wR} 2=0.0436\end{array}$ \\
\hline $\begin{array}{l}\text { Largest Diff. Peak and Hole } \\
\left(\mathrm{e} \times \AA^{-3}\right)\end{array}$ & 1.869 and -1.592 & 0.453 and -0.736 \\
\hline
\end{tabular}




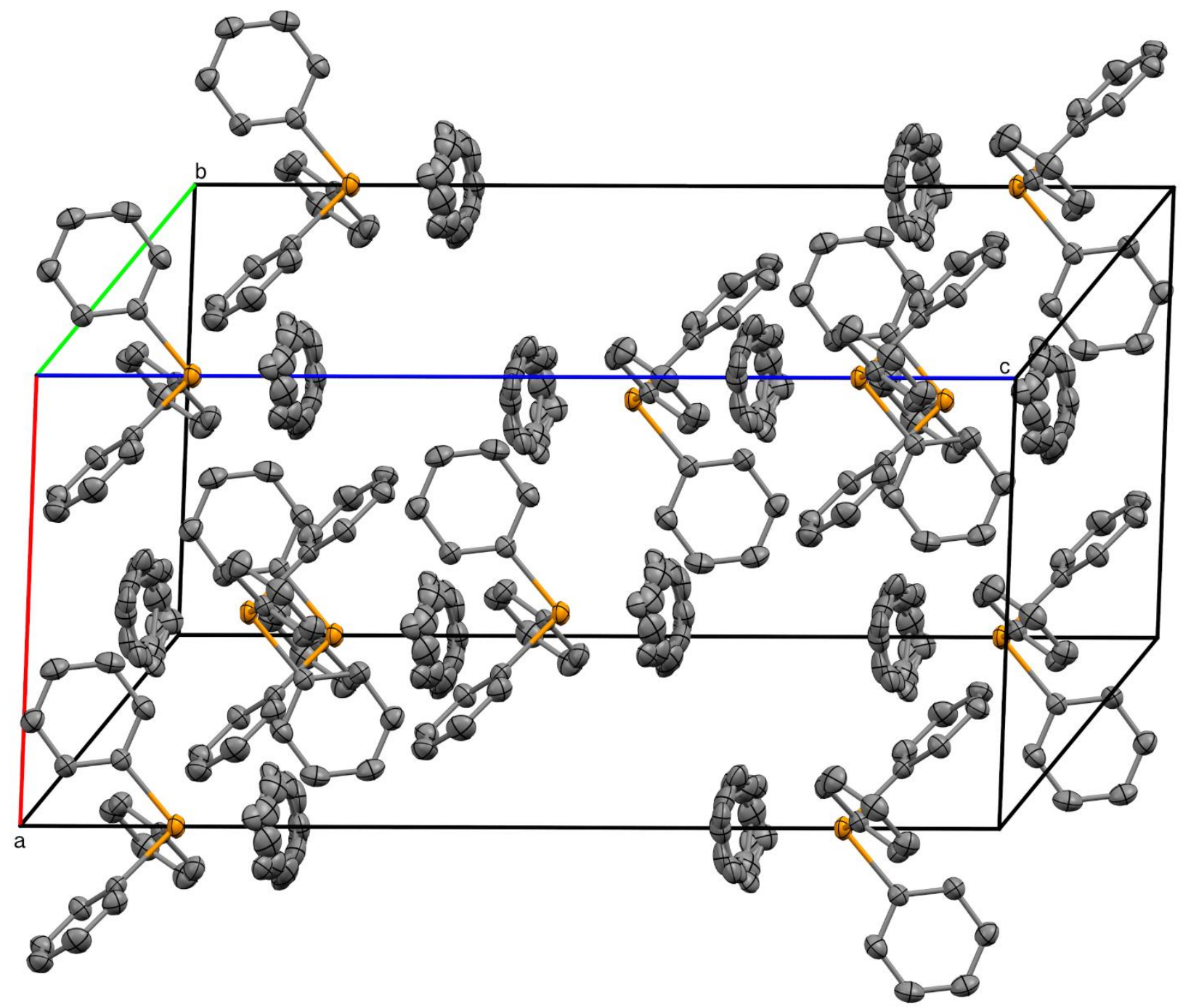

Figure S37. Crystal packing diagram of $\mathbf{1}$ (ellipsoids set at 50\% probability, hydrogen atoms omitted for clarity). 


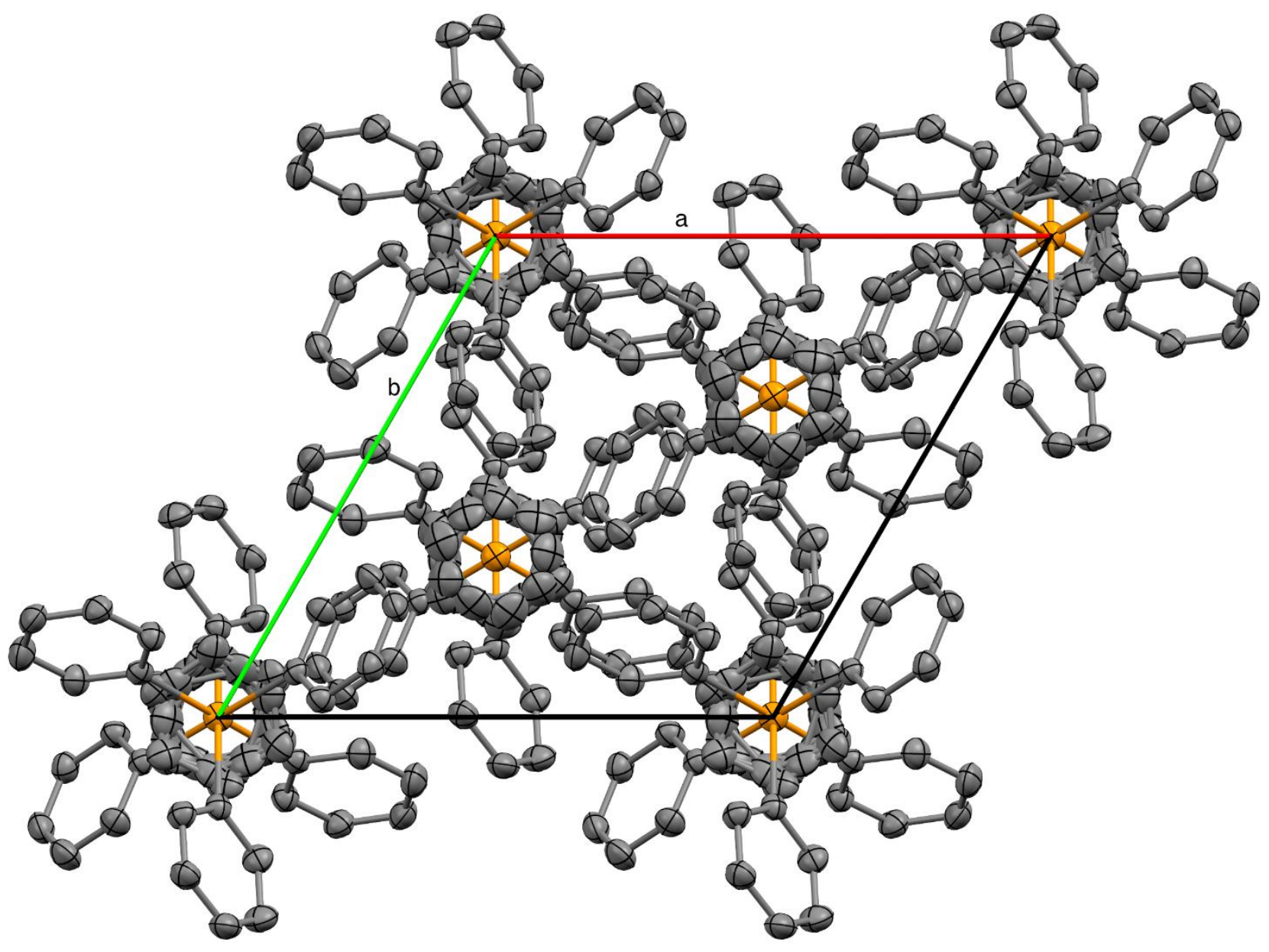

Figure S38. Crystal packing diagram of 1 looking down crystallographic c axis (ellipsoids set at 50\% probability, hydrogen atoms omitted for clarity). 


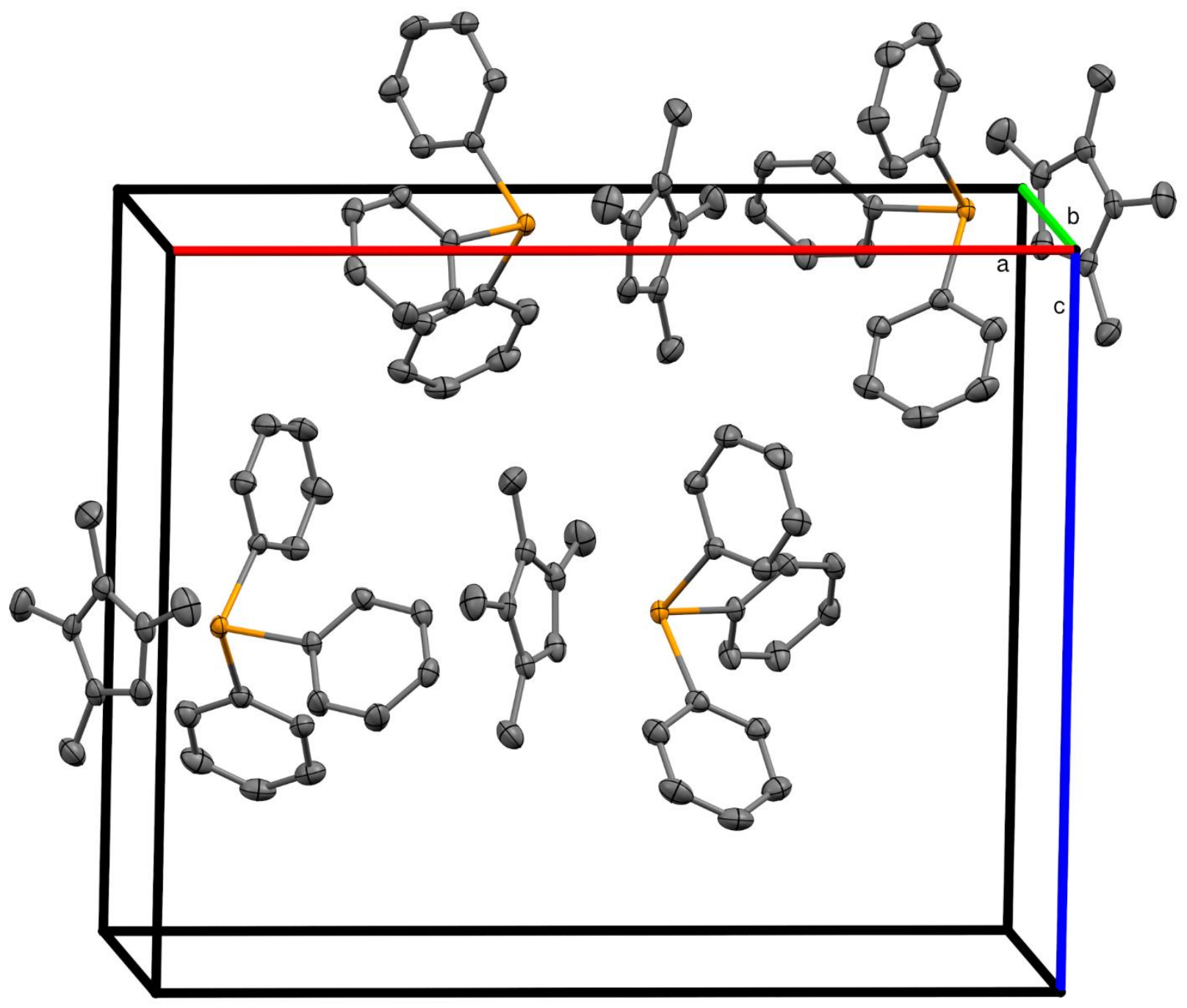

Figure S39. Crystal packing diagram of 2 (ellipsoids set at 50\% probability, hydrogen atoms omitted for clarity). 


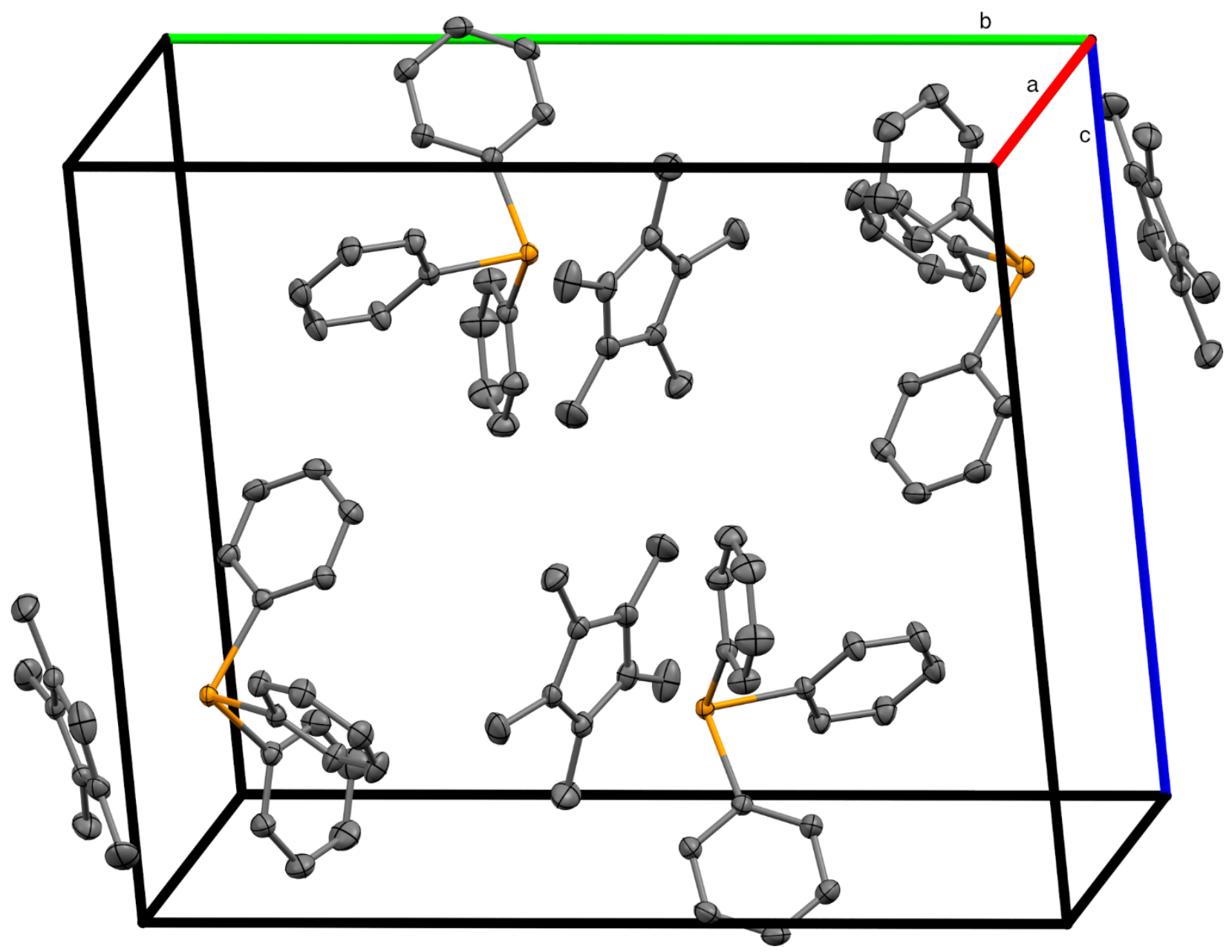

Figure S40. Crystal packing diagram of 3 (ellipsoids set at 50\% probability, hydrogen atoms omitted for clarity). 


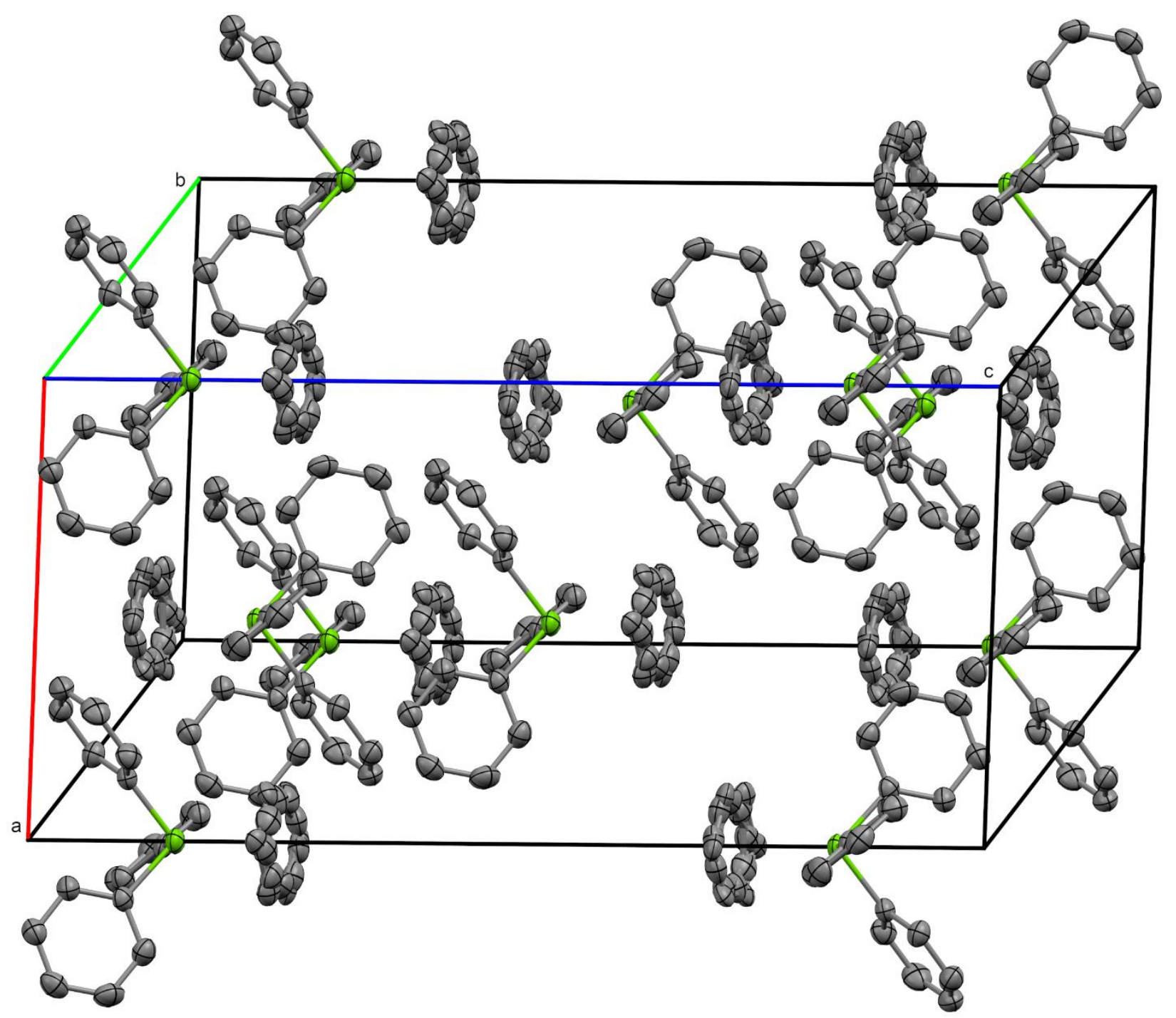

Figure S41. Crystal packing diagram of 4 (ellipsoids set at 50\% probability, hydrogen atoms omitted for clarity). 


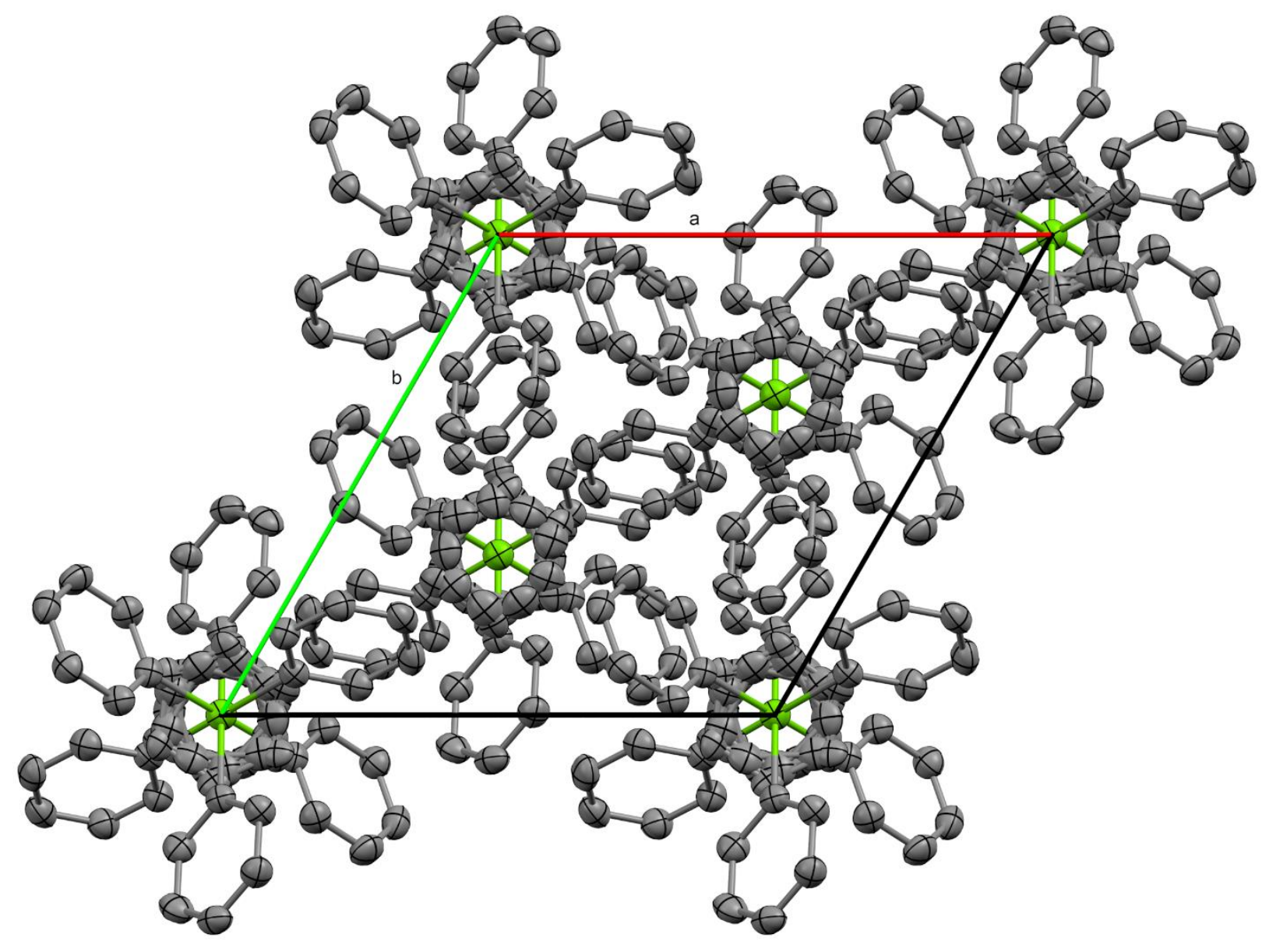

Figure S42. Crystal packing diagram of 4 looking down crystallographic c axis (ellipsoids set at $50 \%$ probability, hydrogen atoms omitted for clarity). 


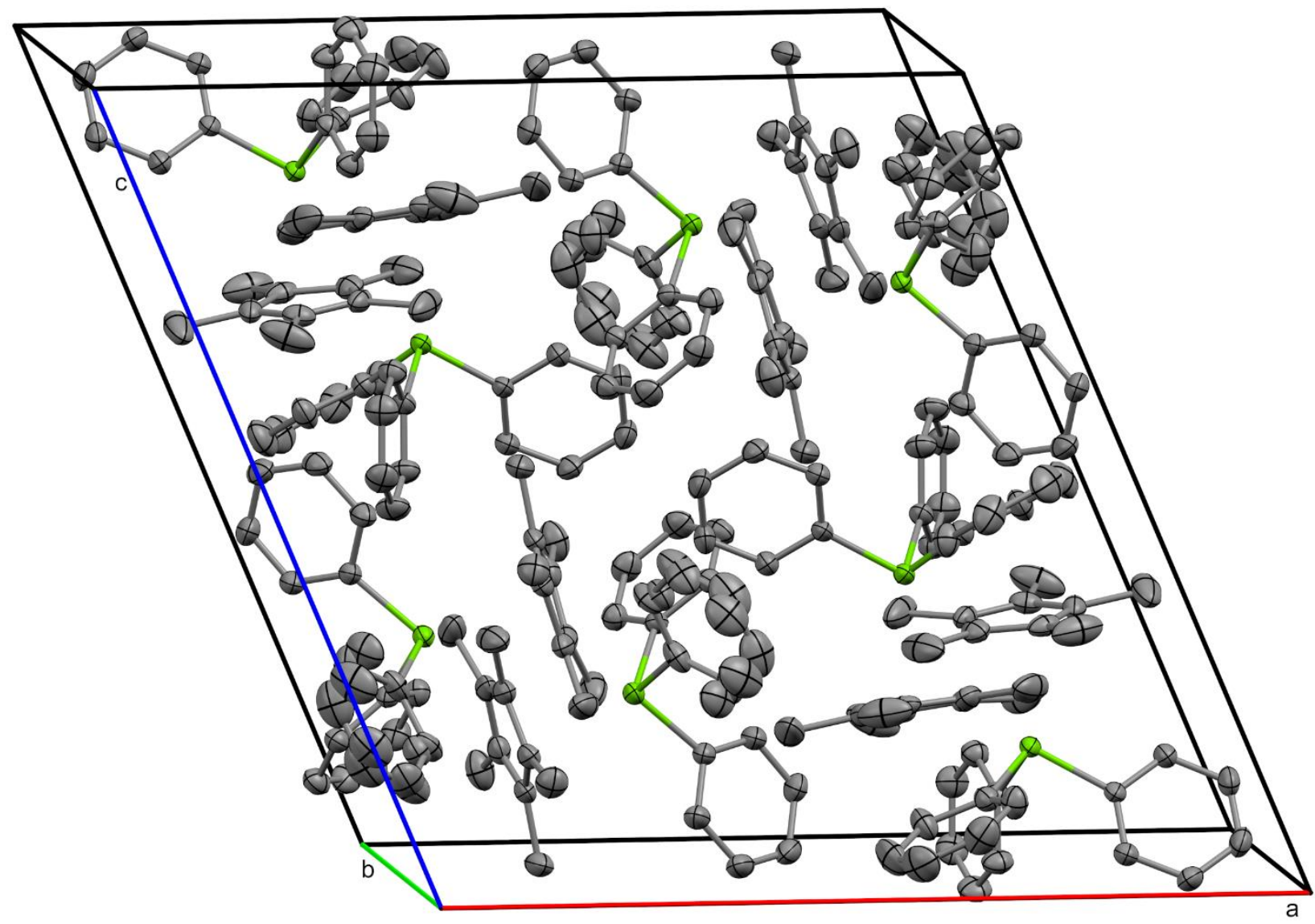

Figure S43. Crystal packing diagram of 5 (ellipsoids set at 50\% probability, hydrogen atoms omitted for clarity). 


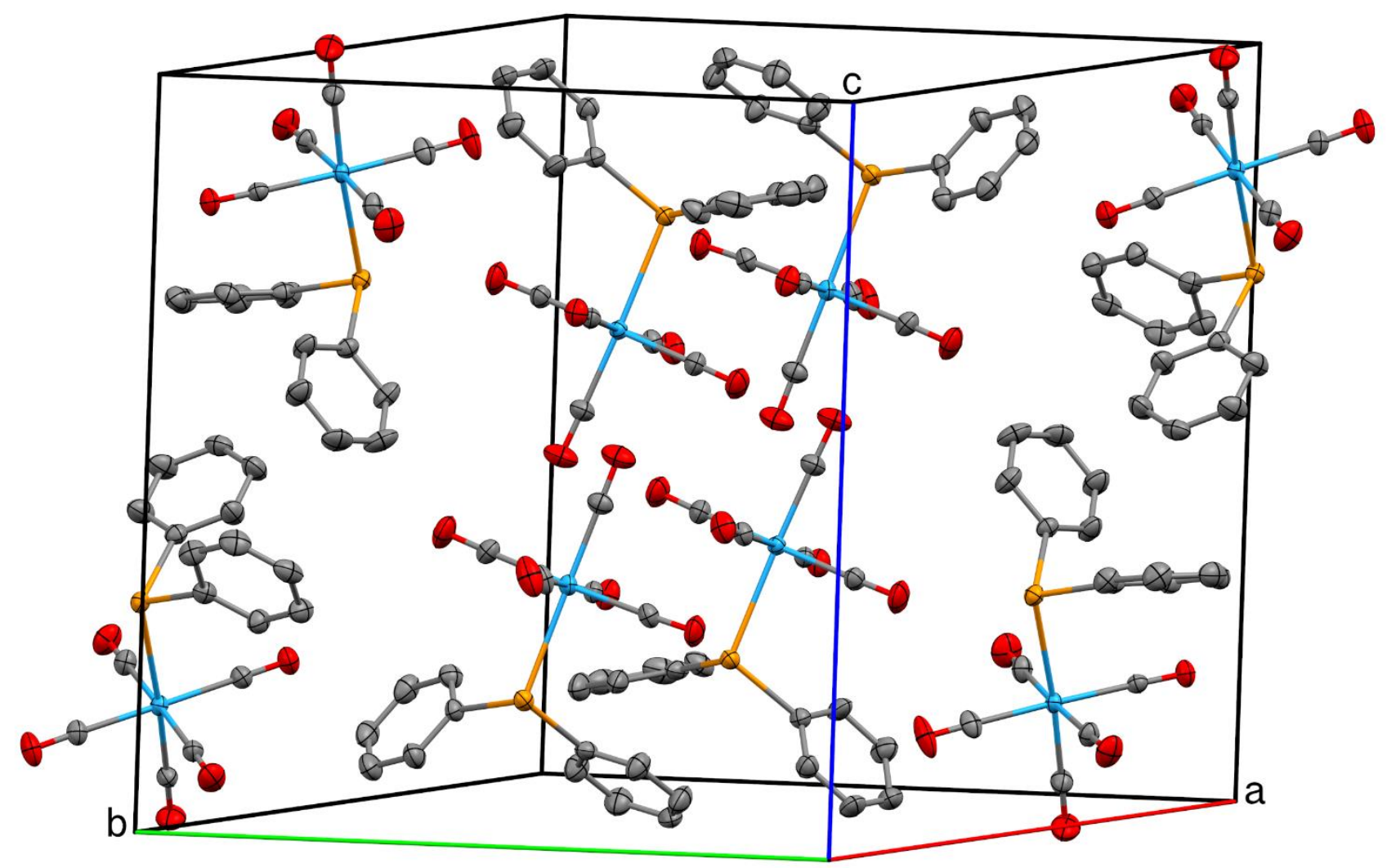

Figure S44. ORTEP crystal packing diagram of $\mathrm{Ph}_{2} \mathrm{Te} \cdot \mathrm{W}(\mathrm{CO})_{5}$ (ellipsoids shown at 50\% probability, hydrogen atoms omitted for clarity). A freshly prepared solution of $\mathrm{W}(\mathrm{CO})_{5} \cdot \mathrm{THF}$ (produced via UV irradiation of $\mathrm{W}(\mathrm{CO})_{6}$ in THF) was added to the yellow oil produced from the thermal decomposition of 5. This mixture was concentrated under vacuum and extracted into pentane. Single crystals of $\mathrm{Ph}_{2} \mathrm{Te} \cdot \mathrm{W}(\mathrm{CO})_{5}$ were obtained from cooling the pentane extract at $-35^{\circ} \mathrm{C}$. Bond distances and angles are similar to the previously reported single crystal structure of this material, though the two crystals exhibit a distinctly different crystal packing orientation of $\mathrm{Ph}_{2} \mathrm{Te} \cdot \mathrm{W}(\mathrm{CO})_{5}$ moieties. ${ }^{15}$ 


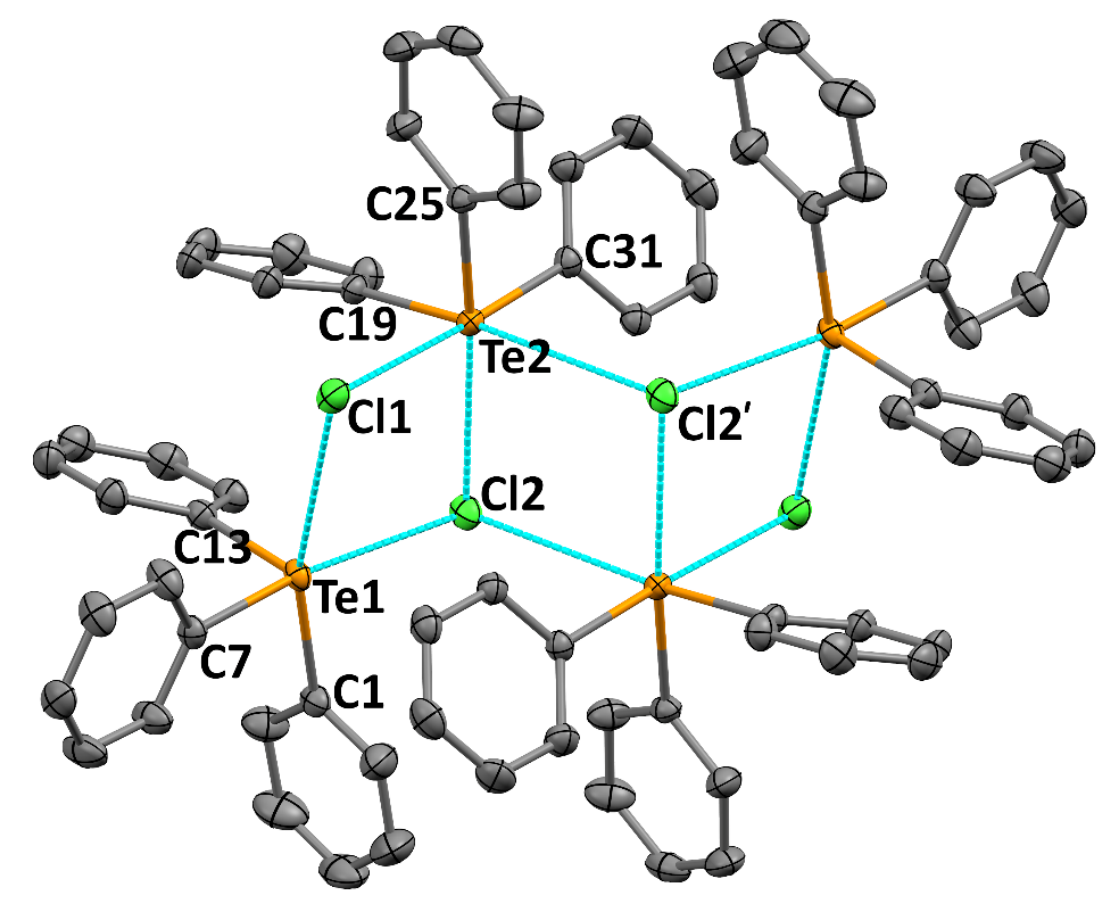

Figure S45. ORTEP diagram of $\mathrm{Ph}_{3} \mathrm{TeCl}$ (ellipsoids shown at 50\% probability, hydrogen atoms and cocrystallized toluene omitted for clarity). Single crystals of $\mathrm{Ph}_{3} \mathrm{TeCl}$ were obtained as an impurity from the reaction of $\mathrm{Ph}_{3} \mathrm{TeCl}$ and $\mathrm{KCp}^{*}$ upon warming and extraction of the crude product into toluene followed by cooling at $-35^{\circ} \mathrm{C}$. Selected distances $(\AA)$ and angles $\left({ }^{\circ}\right)$ : Te1-C1: 2.123(2), Te1-C7: 2.136(1), Te1-C13: 2.125(1), Te2-C19: 2.131(1), Te2-C25: 2.128(2), Te2-C31: 2.144(1), Te1-C11: 3.4641(5), Te1Cl2: 3.0472(6), Te2-Cl1: 3.0948(5), Te2-Cl2: 3.2371(5), Te2-Cl2': 3.5264(4), C1-Te1-C7: 93.11(6), C1Te1-C13: 96.14(6), C7-Te1-C13: 93.95(6), C19-Te2-C25: 94.95(5), C19-Te2-C31: 93.42(5), C25-Te2C31: 92.60(5), Cl1-Te1-Cl2: 89.82(1), Cl1-Te2-Cl2: 93.33(1), Cl2-Te2-Cl2’: 92.58(1), Cl1-Te2-Cl2’: 91.60(1), Te1-Cl1-Te2: 84.73(1), Te1-Cl2-Te2: 89.54(1). 


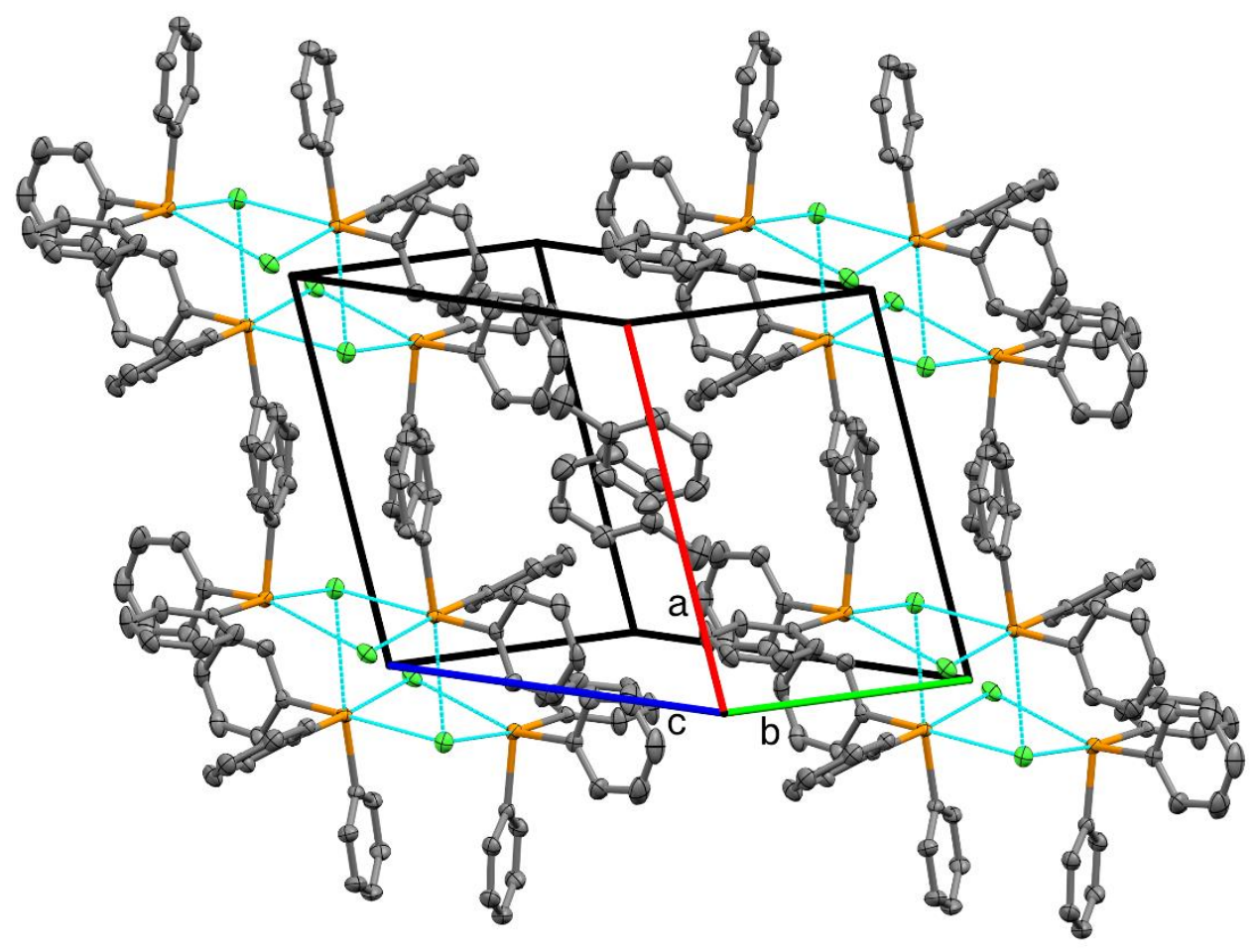

Figure S46. Crystal packing diagram of $\mathrm{Ph}_{3} \mathrm{TeCl}$ (ellipsoids set at 50\% probability, hydrogen atoms omitted for clarity). The halves of each tetramer are related through inversion centers located at the vertices of the unit cell. The tetramers are further related to each other through an inversion center located in the center of the unit cell. Within the tetramer, tellurium centers exist in either pseudo-squarepyramidal (outer) or pseudo-octahedral (inner) geometry. This is consistent with a previously reported crystal structure of dimeric $\mathrm{Ph}_{3} \mathrm{TeCl}$ showing pseudo-square-pyramidal geometry, though dissimilar to the reported structure of monomeric $\mathrm{Ph}_{3} \mathrm{TeCl}$ which displays a pseudo-tetrahedral geometry. ${ }^{16,17}$ 


\section{Computational Details}

The structures were optimized with the metaGGA functional TPSS ${ }^{18,19}$ and a triple zeta basis set ${ }^{20}$ with a polarization function TZP in the Amsterdam Density Functional (ADF) engine, ${ }^{21}$ part of the Amsterdam Modeling Suite (AMS, version 2020.102). The basis was all-electron and the BeckeGrid was set to verygood. ${ }^{22}$ This level of theory was applied to all calculations and the structures and isosurfaces $(0.03)$ were visualized with the ADF graphic user interface (GUI), ADFView. The energy decomposition analysis (EDA) was performed in ADF. The bond order analysis included the formalisms by Mayer, ${ }^{23}$ Gopinathan-Jug (G-J), ${ }^{24}$ and Nalewajski-Mrozek (N-M) ${ }^{25,26}$ as implemented in ADF.

\section{$[\mathrm{Cp}]\left[\mathrm{TePh}_{3}\right](1)$}

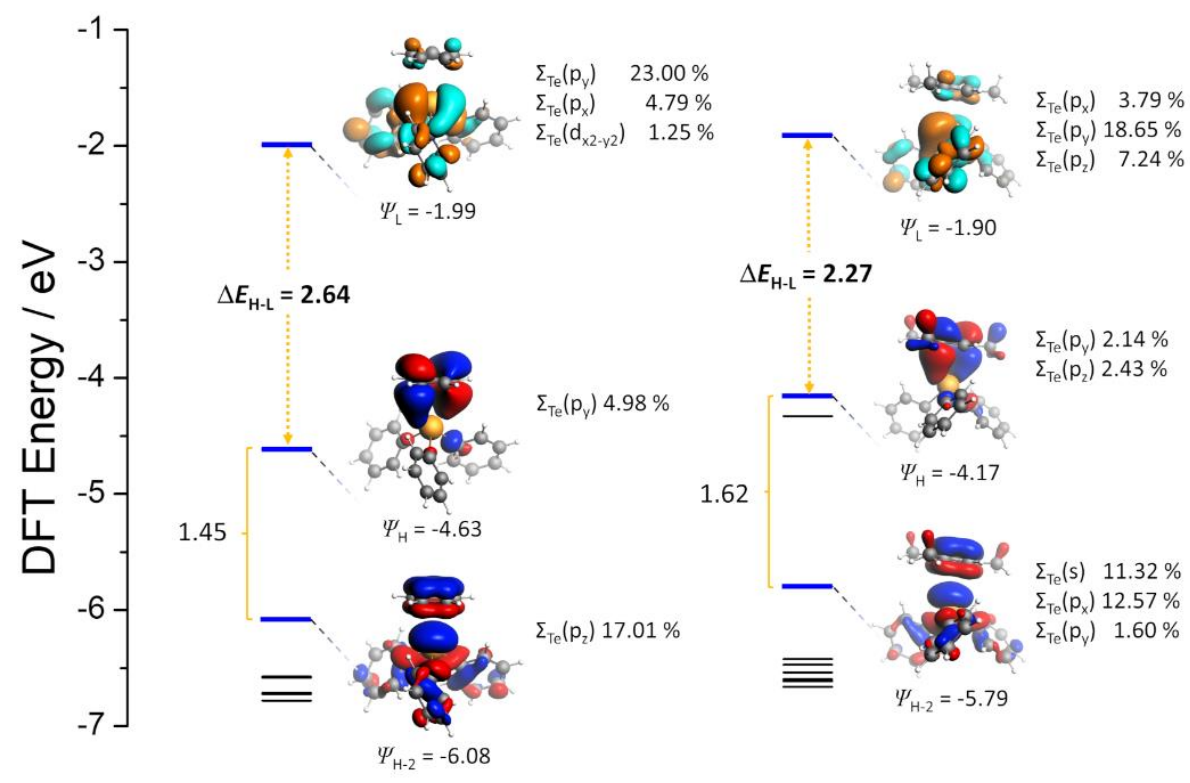

$\left[\mathrm{Cp}^{*}\right]\left[\mathrm{TePh}_{3}\right](3)$

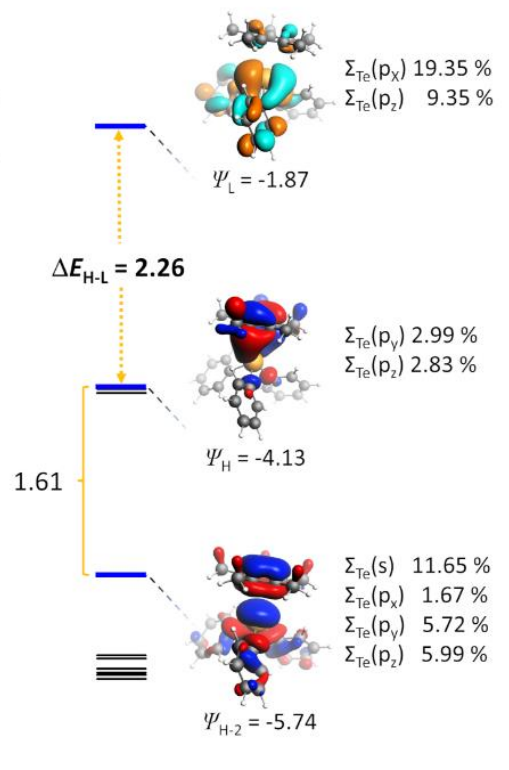

Figure S47. Molecular orbitals of the complexes 1-3, including the lone pair orbitals of the Te center. 
$[\mathrm{Cp}]\left[\mathrm{SePh}_{3}\right](4)$

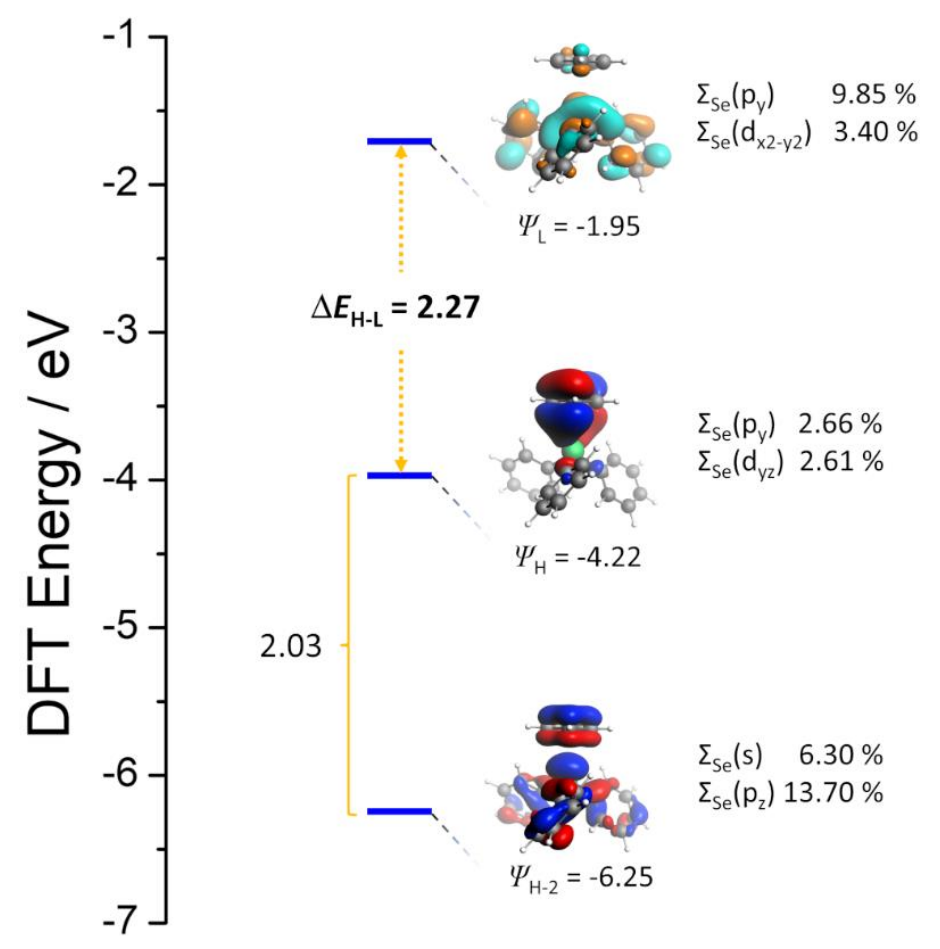

$[\mathrm{Cp} *]\left[\mathrm{SePh}_{3}\right](5)$

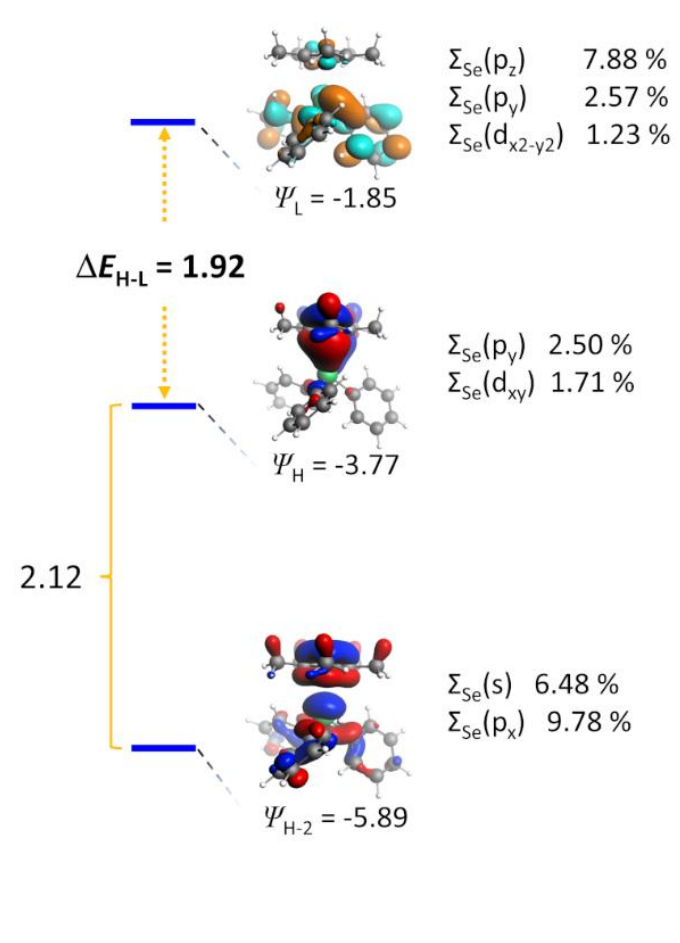

Figure S48. Molecular orbitals of the complexes $\mathbf{4}$ and $\mathbf{5}$, including the lone pair orbitals of the Se center. 

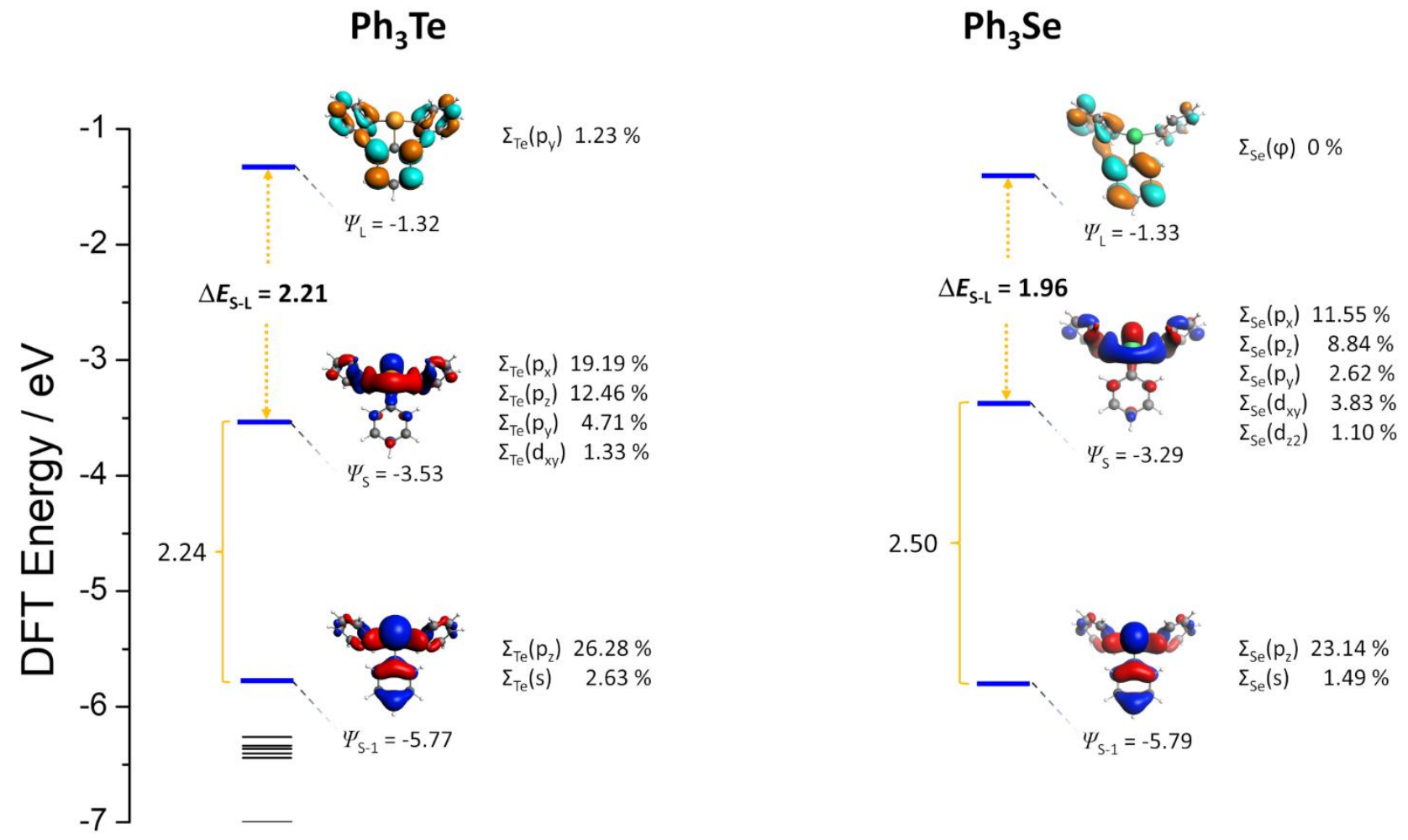

Figure S49. Molecular orbitals of the fragments $\mathrm{Ph}_{3} \mathrm{Te}$ and $\mathrm{Ph}_{3} \mathrm{Se}$, including the lone pair orbitals of the Te and Se center.

$\mathrm{Cp}$ (from 1)

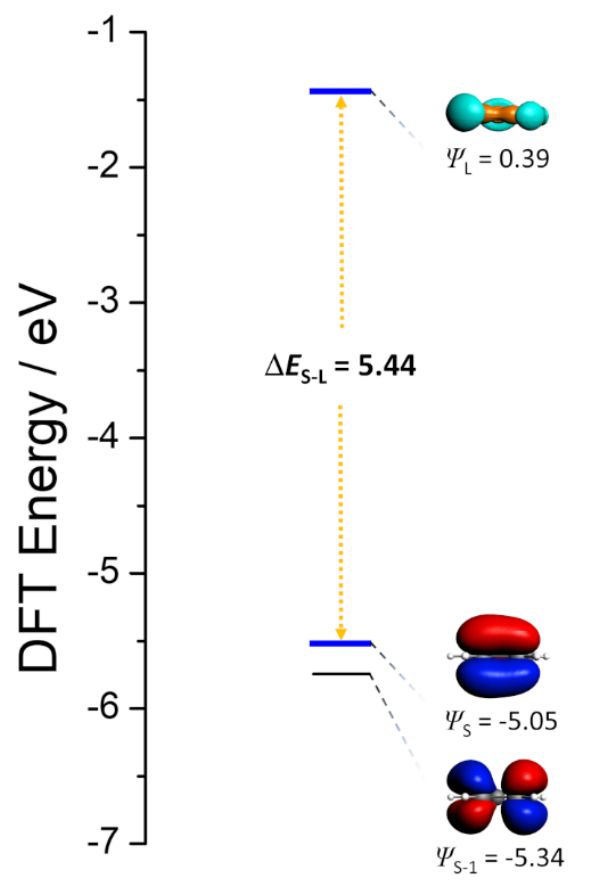

$\mathrm{Cp}^{\mathrm{Me} 4}$ (from 2)

Cp* (from 3)

Figure S50. Molecular orbitals of the Cp rings.
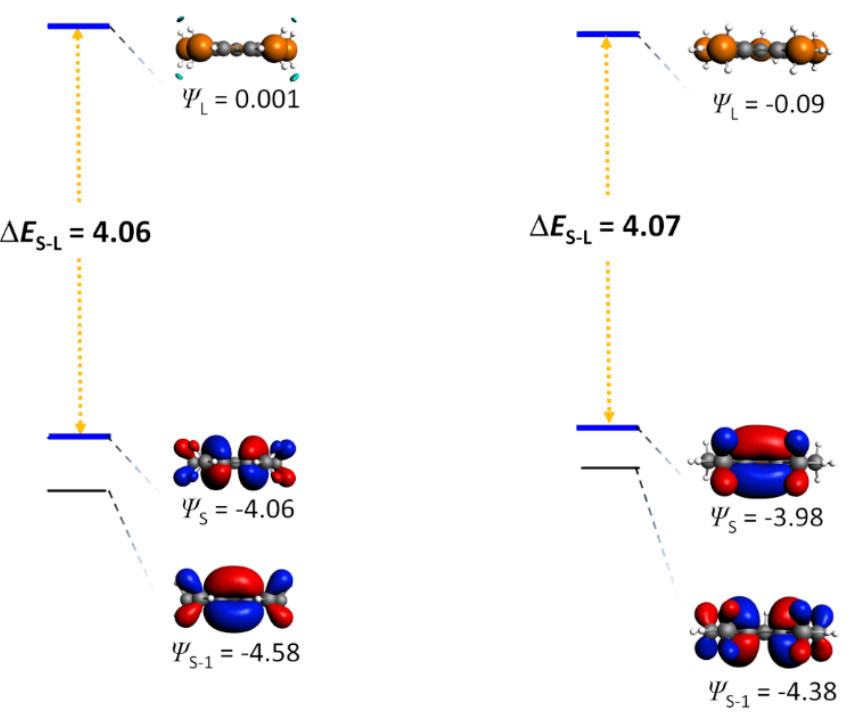
Table S4. Te- $\mathrm{C}_{\mathrm{Cp}}$ bond orders for compound $\mathbf{1}$.

\begin{tabular}{cccccc}
\multicolumn{3}{c}{ DIST. [A] } & \multicolumn{5}{c}{ BOND-ORDERS } \\
(THRESHOLD $=0.010)$
\end{tabular}

Table S5. Te- $\mathrm{C}_{\mathrm{Cp}}$ bond orders for compound 2.

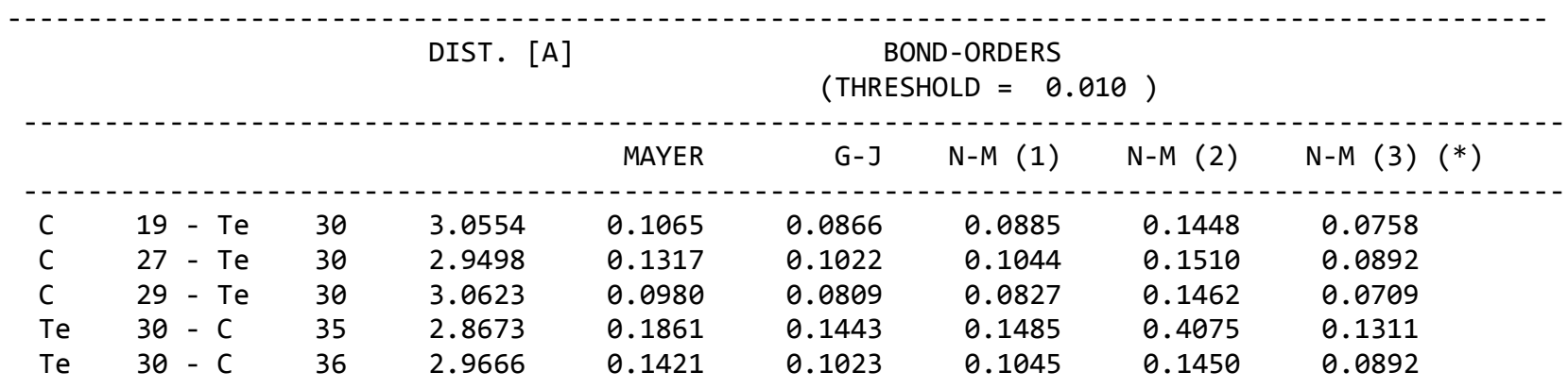

Table S6. Te- $\mathrm{C}_{\mathrm{Cp}}$ bond orders for compound 3 .

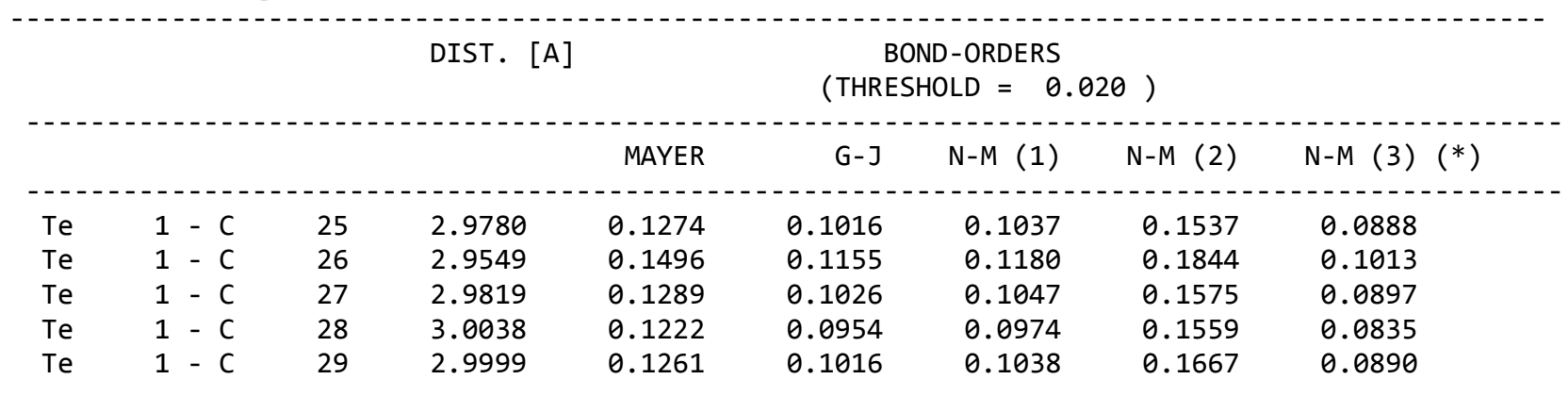

Table S7. Se- $\mathrm{C}_{\mathrm{Cp}}$ bond orders for compound 4.

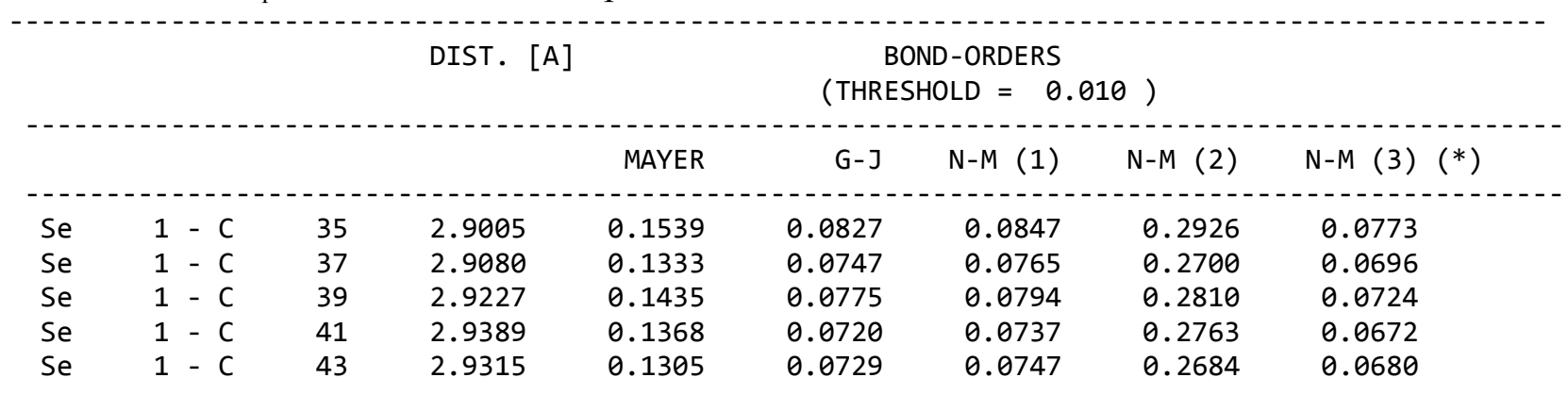


Table S8. Se-C $\mathrm{C}_{\mathrm{Cp}}$ bond orders for compound $\mathbf{5}$.

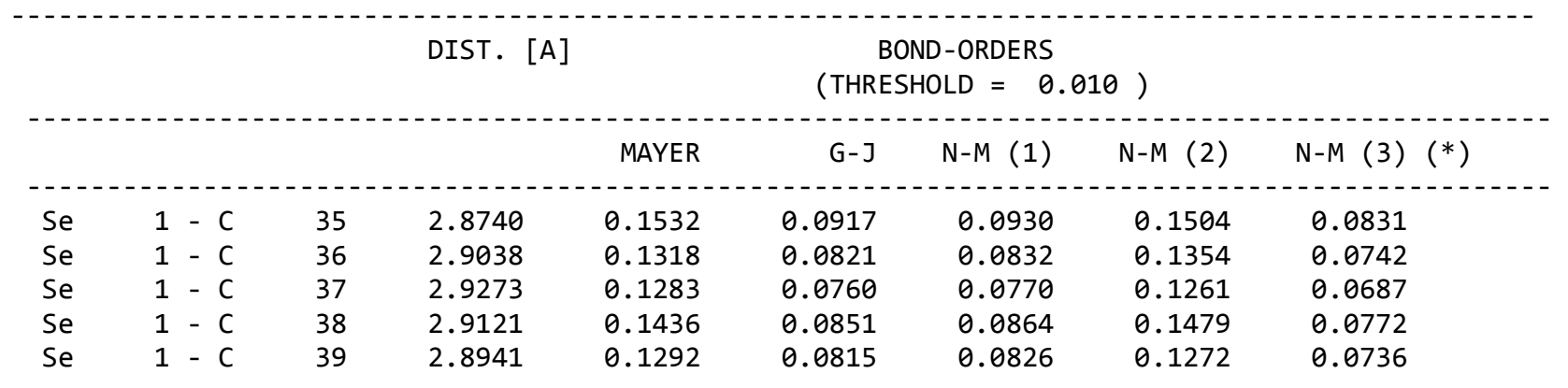


Table S9. Energy decomposition analysis (EDA) for compound $\mathbf{1}$ and its molecular fragments.

\begin{tabular}{ccccc} 
Energy Term & {$[\mathrm{Cp}]\left[\mathrm{TePh}_{3}\right](\mathbf{1})$} & {$\left[\mathrm{Ph}_{3} \mathrm{Te}\right]$} & {$[\mathrm{Cp}]$} & $\Delta E_{\mathrm{f}}(\mathbf{1}) / \mathrm{kcal} \mathrm{mol}^{-1}$ \\
\hline Electrostatic energy & -5247.09 & -4078.99 & -1078.33 & -89.77 \\
Kinetic energy & 5898.96 & 4561.36 & 1295.51 & 42.09 \\
Coulomb energy & -1169.73 & -889.2 & -338.3 & 57.77 \\
XC energy & -5940.97 & -4592.78 & -1291.23 & -56.96 \\
Total Bonding Energy & -6458.82 & -4999.61 & -1412.35 & -46.86
\end{tabular}

Table S10. Energy decomposition analysis (EDA) for compound $\mathbf{2}$ and its molecular fragments.

\begin{tabular}{ccccc} 
Energy Term & {$\left[\mathrm{Cp}^{\mathrm{Me}}\right]\left[\mathrm{TePh}_{3}\right](\mathbf{2})$} & {$\left[\mathrm{Ph}_{3} \mathrm{Te}\right]$} & {$\left[\mathrm{Cp}^{\mathrm{Me} 4}\right]$} & $\Delta E_{\mathrm{f}}(\mathbf{2}) / \mathrm{kcal} \mathrm{mol}^{-1}$ \\
\hline Electrostatic energy & -6253.07 & -4078.99 & -2096.26 & -77.82 \\
Kinetic energy & 7339.31 & 4561.36 & 2739.46 & 38.49 \\
Coulomb energy & -1735.81 & -889.2 & -907.48 & 60.87 \\
XC energy & -7354.97 & -4592.78 & -2705.69 & -56.5 \\
Total Bonding Energy & -8004.55 & -4999.61 & -2969.97 & -34.97
\end{tabular}

Table S11. Energy decomposition analysis (EDA) for compound $\mathbf{3}$ and its molecular fragments.

\begin{tabular}{ccccc} 
Energy Term & {$\left[\mathrm{Cp}^{*}\right]\left[\mathrm{TePh}_{3}\right](\mathbf{3})$} & {$\left[\mathrm{Ph}_{3} \mathrm{Te}\right]$} & {$\left[\mathrm{Cp}^{*}\right]$} & $\Delta E_{\mathrm{f}}(\mathbf{3}) / \mathrm{kcal} \mathrm{mol}^{-1}$ \\
\hline Electrostatic energy & -6502.36 & -4078.99 & -2349.36 & -74.01 \\
Kinetic energy & 7686.92 & 4561.36 & 3096.22 & 29.34 \\
Coulomb energy & -1869.18 & -889.2 & -1043.31 & 63.33 \\
XC energy & -7705.32 & -4592.78 & -3059.41 & -53.13 \\
Total Bonding Energy & -8389.94 & -4999.61 & -3355.86 & -34.47
\end{tabular}

Table S12. Energy decomposition analysis (EDA) for compound $\mathbf{4}$ and its molecular fragments.

\begin{tabular}{ccccc} 
Energy Term & {$[\mathrm{Cp}]\left[\mathrm{SePh}_{3}\right](\mathbf{4})$} & {$\left[\mathrm{Ph}_{3} \mathrm{Se}\right]$} & {$[\mathrm{Cp}]$} & $\Delta E_{\mathrm{f}}(\mathbf{4}) / \mathrm{kcal} \mathrm{mol}^{-1}$ \\
\hline Electrostatic energy & -5285.48 & -4102.28 & -1078.33 & -104.87 \\
Kinetic energy & 5913.96 & 4578.85 & 1295.51 & 39.6 \\
Coulomb energy & -1147.05 & -887.16 & -338.3 & 78.41 \\
XC energy & -5953.41 & -4603.62 & -1291.23 & -58.56 \\
Total Bonding Energy & -6471.98 & -5014.2 & -1412.35 & -45.43
\end{tabular}

Table S13. Energy decomposition analysis (EDA) for compound $\mathbf{5}$ and its molecular fragments.

\begin{tabular}{ccccc} 
Energy Term & {$\left[\mathrm{Cp}^{*}\right]\left[\mathrm{SePh}_{3}\right](\mathbf{5})$} & {$\left[\mathrm{Ph}_{3} \mathrm{Se}\right]$} & {$\left[\mathrm{Cp}^{*}\right]$} & $\Delta E_{\mathrm{f}}(\mathbf{5}) / \mathrm{kcal} \mathrm{mol}^{-1}$ \\
\hline Electrostatic energy & -6539.19 & -4102.28 & -2349.36 & -87.55 \\
Kinetic energy & 7690.89 & 4578.85 & 3096.22 & 15.82 \\
Coulomb energy & -1839.14 & -887.16 & -1043.31 & 91.33 \\
XC energy & -7714.01 & -4603.62 & -3059.41 & -50.98 \\
Total Bonding Energy & -8401.45 & -5014.2 & -3355.86 & -31.39
\end{tabular}




\section{References}

(1) Günther, W. H. H.; Nepywoda, J.; Chu, J. Y. C. Methods in Chalcogen Chemistry: V. A New Reagent for the Synthesis of Aromatic Tellurium Compounds. J. Organomet. Chem. 1974, 74, 79-84.

(2) Singh, A. K.; Basumatary, J. K. Triphenyltellurium(IV) Dithiocarbamates, Xanthates, and Dithiophosphates. J. Organomet. Chem. 1989, 364, 73-77.

(3) Crowell, J. H.; Bradt, W. E. The Preparation of Tri-Para-Tolylselenonium Chloride by Means of the Friedel—Crafts Reaction with Selenium Dioxide. J. Am. Chem. Soc. 1933, 55, 1500-1502.

(4) Rodger, C.; Sheppard, N.; McFarlane, C.; McFarlane, W. Group VI-Oxygen, Sulphur, Selenium and Tellurium. In NMR and the Periodic Table; Harris, R. K., Mann, B. E., Eds.; Academic Press: London, 1978; pp 383-419.

(5) Bachmann, S.; Gernert, B.; Stalke, D. Solution Structures of Alkali Metal Cyclopentadienides in THF Estimated by ECC-DOSY NMR-Spectroscopy (Incl. Software). Chem. Commun. 2016, 52, 12861-12864.

(6) Bruker (2016). Apex3 V2017.3-0, Saint V8.38A. Bruker AXS Inc.: Madison, Wisconsin: USA, 2013-2014.

(7) SHELXTL Suite of Programs, Version 6.14. Bruker Advanced X-ray Solutions, Bruker AXS Inc.: Madison, Wisconsin: USA, 2000-2003.

(8) Sheldrick, G. M. A Short History of SHELX. Acta Crystallogr. Sect. A Found. Crystallogr. 2008, 64, 112-122.

(9) Sheldrick, G. M. SHELXL. University of Göttingen, Germany, 2018.

(10) Sheldrick, G. M. Crystal Structure Refinement with SHELXL. Acta Crystallogr. Sect. C Struct. Chem. 2015, 71, 3-8.

(11) Hübschle, C. B.; Sheldrick, G. M.; Dittrich, B. ShelXle : A Qt Graphical User Interface for SHELXL. J. Appl. Crystallogr. 2011, 44, 1281-1284.

(12) Sheldrick, G. M. CELL_NOW. University of Göttingen, Germany, 2008.

(13) Cooper, R. I.; Gould, R. O.; Parsons, S.; Watkin, D. J. The Derivation of Non-Merohedral Twin Laws during Refinement by Analysis of Poorly Fitting Intensity Data and the Refinement of Non-Merohedrally Twinned Crystal Structures in the Program CRYSTALS. J. Appl. Crystallogr. 2002, 35, 168-174.

(14) Spek, A. L. Single-Crystal Structure Validation with the Program PLATON. J. Appl. Crystallogr. 2003, 36, 7-13.

(15) Liaw, W.-F.; Chiang, M.-H.; Lai, C.-H.; Chiou, S.-J.; Lee, G.-H.; Peng, S.-M. Metal Complexes of Telluroether: Crystal Structure of $\left(\mathrm{Ph}_{2} \mathrm{Te}\right) \mathrm{Fe}(\mathrm{CO})_{3} \mathrm{I}_{2}$ and $\left(\mathrm{Ph}_{2} \mathrm{Te}\right) \mathrm{W}(\mathrm{CO})_{5}$. Inorg. Chem. 1994, 33, 2493-2494.

(16) Chopra, A.; Jain, S.; Srivastava, S. K.; Gupta, S. K.; Butcher, R. J. Triphenyltellurium Chloride. Acta Crystallogr. Sect. E Struct. Reports Online 2014, 70, o421-0422.

Ziolo, R. F.; Extine, M. Crystal and Molecular Structure of Unsolvated Triphenyltelluronium Chloride, $\left(\mathrm{C}_{6} \mathrm{H}_{5}\right)_{3} \mathrm{TeCl}$. Inorg. Chem. 1980, 19, 2964-2967.

Tao, J.; Perdew, J. P.; Staroverov, V. N.; Scuseria, G. E. Climbing the Density Functional Ladder: Nonempirical Meta-Generalized Gradient Approximation Designed for Molecules and Solids. Phys. Rev. Lett. 2003, 91, 146401.

Staroverov, V. N.; Scuseria, G. E.; Tao, J.; Perdew, J. P. Comparative Assessment of a New Nonempirical Density Functional: Molecules and Hydrogen-Bonded Complexes. J. Chem. Phys. 2003, 119, 12129-12137.

(20) Van Lenthe, E.; Baerends, E. J. Optimized Slater-Type Basis Sets for the Elements 1-118. J. Comput. Chem. 2003, 24, 1142-1156.

(21) te Velde, G.; Bickelhaupt, F. M.; Baerends, E. J.; Fonseca Guerra, C.; van Gisbergen, S. J. A.; 
Snijders, J. G.; Ziegler, T. Chemistry with ADF. J. Comput. Chem. 2001, 22, 931-967.

(22) Franchini, M.; Philipsen, P. H. T.; Visscher, L. The Becke Fuzzy Cells Integration Scheme in the Amsterdam Density Functional Program Suite. J. Comput. Chem. 2013, 34, 1819-1827.

(23) Mayer, I. Charge, Bond Order and Valence in the AB Initio SCF Theory. Chem. Phys. Lett. 1983, 97, 270-274.

(24) Gopinathan, M. S.; Jug, K. Valency. I. A Quantum Chemical Definition and Properties. Theor. Chim. Acta 1983, 63, 497-509.

(25) Nalewajski, R. F.; Mrozek, J. Modified Valence Indices from the Two-Particle Density Matrix. Int. J. Quantum Chem. 1994, 51, 187-200.

(26) Nalewajski, R. F.; Mrozek, J.; Michalak, A. Two-Electron Valence Indices from the Kohn-Sham Orbitals. Int. J. Quantum Chem. 1997, 61, 589-601. 